Florida International University FIU Digital Commons

4-1-2016

\title{
El Bildungsroman femenino de Ángeles Mastretta y Carmen Boullosa: Hacia una perspectiva posmoderna
}

Rebeca Cunill

rcuni001@fiu.edu

DOI: $10.25148 /$ etd.FIDC000220

Follow this and additional works at: https://digitalcommons.fiu.edu/etd

Part of the Latin American Literature Commons

\section{Recommended Citation}

Cunill, Rebeca, "El Bildungsroman femenino de Ángeles Mastretta y Carmen Boullosa: Hacia una perspectiva posmoderna" (2016). FIU Electronic Theses and Dissertations. 2497.

https://digitalcommons.fiu.edu/etd/2497 


\title{
FLORIDA INTERNATIONAL UNIVERSITY
}

Miami, Florida

\section{EL BILDUNGSROMAN FEMENINO DE ÁNGELES MASTRETTA Y CARMEN BOULLOSA: HACIA UNA PERSPECTIVA POSMODERNA}

A dissertation submitted in partial fulfillment of the

requirements for the degree of

DOCTOR OF PHILOSOPHY

\author{
in \\ SPANISH \\ by \\ Rebeca Cunill
}

2016 


\section{To: Dean John Stack}

Steven J. Green School of International and Public Affairs

This dissertation, written by Rebeca Cunill, and entitled El Bildungsroman femenino de Ángeles Mastretta y Carmen Boullosa: Hacia una perspectiva posmoderna, having been approved in respect to style and intellectual content, is referred for your judgement.

We have read this dissertation and recommend that it be approved.

$\begin{array}{r}\hline \text { Nicola Gavioli } \\ \hline \text { Santiago Juan-Navarro } \\ \hline \text { Sherry Johnson } \\ \hline \text { Erik Camayd-Freixas, Major Professor }\end{array}$

Date of Defense: April 1, 2016

This dissertation of Rebeca Cunill is approved.

Dean John Stack

Steven J. Green School of International and Public Affairs

Andrés G. Gil

Vice President for Research and Economic Development and Dean of the University Graduate School

Florida International University, 2016 
(C) Copyright 2016 by Rebeca Cunill

All rights reserved. 


\section{DEDICATORIA}

Para Mirella 


\section{RECONOCIMIENTOS}

Quiero agradecer a todos los miembros del comité por su paciencia y apoyo en

todas las etapas de este proyecto. Agradezco especialmente al Dr. Erik Camayd-Freixas por su generosa guía y asesoramiento profesional. Sin sus siempre sabias y acertadas observaciones no hubiera podido concluir exitosamente este trabajo. Quiero agradecer además al departamento de Lenguas Modernas por el apoyo académico y financiero que me brindaron en mis años de estudios graduados. 


\section{ABSTRACT OF THE DISSERTATION \\ EL BILDUNGSROMAN FEMENINO DE ÁNGELES MASTRETTA Y CARMEN BOULLOSA: HACIA UNA PERSPECTIVA POSMODERNA}

by

Rebeca Cunill

Florida International University, 2016

Miami, Florida

\section{Professor Erik Camayd-Freixas, Major Professor}

The traditional Bildungsroman that originated in Europe toward the end of the 18th Century embodied the concept of progress and the belief in the Enlightenment ideals of universality, knowledge and the search for truth. In the classic model of the genre the values of the society represented, those of modernity, are ultimately legitimized. In this dissertation, I argue that the female Bildungsroman of Ángeles Mastretta and Carmen Boullosa respond to a fundamentally postmodern aesthetics and ideological framework. In their novels, “Arráncame la vida” (1985), “Antes” (1989), “Mal de amores” (1995) and “Treinta años” (1999), the Mexican writers challenge the legitimacy of the modern ideals of progress and individual maturity that characterized the traditional, European, male Bildungsroman. These texts reject the essentialist and utopian representation of progressive personal growth and achievement that would invariably lead to a fixed state of maturity.

My study of Mastretta’s and Boullosa's representations of the Bildung process draws on postmodern theories such as those proposed by Jean-François Lyotard, Linda 
Hutcheon and Zygmunt Bauman, among others. Their protagonists’ subversive and contestatory attitudes toward many of modernity's most disseminated master narratives the traditional concept of maturity, of a coherent sense of self and of childhood and adolescence as steps toward a definitive personal identity, suggest a revision of the traditional principles of the genre. In the context of contemporary Mexican society, these texts ultimately suggest the inadequacy of the conventional form of the coming of age novel to represent the process of individual development. In postmodern Mexico, as this study demonstrates, the referents of modernity have lost their hegemonic value and therefore, the conventional model of the coming of age novel must be reinvented. The implications of the novelists' reconceptualization of the genre are twofold; on the one hand, it suggests an emancipatory defiance of the modern concepts of individual progress and perfectibility, while on the other, it demands a high degree of tolerance toward the ambiguous and plural nature of postmodern representations of women’s formative journeys. 
ÍNDICE

CAPÍTULO

PÁGINA

INTRODUCCIÓN: DE LAS INQUIETUDES DEL BILDUNGSROMAN

CLÁSICO AL BILDUNGSROMAN POSMODERNO DE ÁNGELES

MASTRETTA Y CARMEN BOULLOSA .1

1. ARRÁNCAME LA VIDA (1985) …......................................20

1.1. PROBLEMÁTICA FEMENINA Y FEMINISMO: (RE)VISIONES

DEL MODELO CLÁSICO DE LA NOVELA DE FORMACIÓN .................20

1.2. REPRESENTACIONES POSMODERNAS DE FORMACIÓN

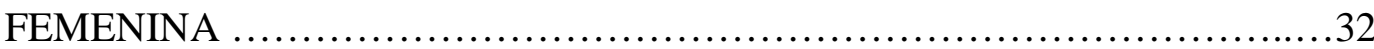

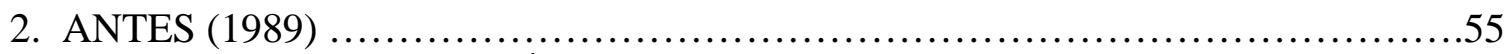

2.1. REPRESENTACIÓN DE ORFANDAD, INTERIORIDAD Y

TRAUMA INFANTIL ....................................................55

2.2. EL BILDUNG TRONCHADO O LA POÉTICA BOULLOSIANA

DE LA POSMODERNIDAD ..................................................72

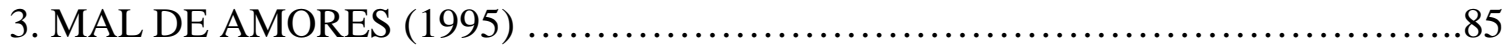

3.1. "TÚ NACISTE CON LUZ ELÉCTRICA": LA IMPORTANCIA

DE LA CRIANZA A LAS PUERTAS DEL NUEVO SIGLO ..................85

3.2. VIDAS REVOLUCIONARIAS Y REVOLUCIÓN:

REPLANTEAMIENTOS HISTÓRICOS E INCLUSIÓN FEMENINA ..........103

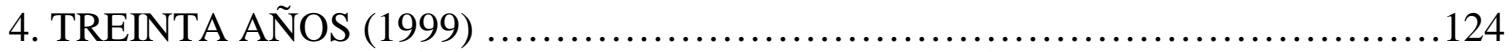

4.1. FORMACIÓN A PARTIR DE LA INVENCIÓN: MEMORIA, NOSTALGIA E IMAGINACIÓN .124

4.2. DESARTICULANDO EL MUNDO "FIEL A LAS LEYES

DE LA FÍSICA" 141



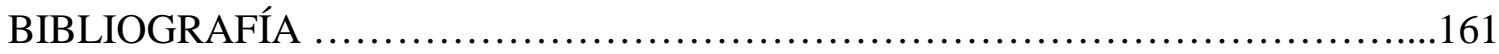






\section{INTRODUCCIÓN}

\section{DE LAS INQUIETUDES DEL BILDUNGSROMAN \\ CLÁSICO AL BILDUNGSROMAN POSMODERNO DE ÁNGELES MASTRETTA Y CARMEN BOULLOSA}

El auge de la literatura escrita por mujeres en América Latina durante las décadas de 1980 y 1990 corresponde con la difusión de la corriente crítica posmoderna que propusiera Jean-François Lyotard en 1979. El presente estudio se apoya en el paradigma discursivo de la posmodernidad para analizar el Bildungsroman de Ángeles Mastretta y Carmen Boullosa, dado que ambas autoras optan por una renovación del Bildungsroman tradicional con el fin de representar los procesos de formación femenina en el contexto histórico e intelectual posmoderno del México contemporáneo. Tanto Mastretta como Boullosa se apoyan en la crisis de legitimación que plantea la posmodernidad, para problematizar la representación del proceso de formación femenino. A diferencia de la perspectiva lineal que seguía el Bildungsroman clásico donde el proceso de madurez se concebía como una trayectoria cronológica y progresiva, Mastretta y Boullosa reconceptualizan el género ofreciendo una alternativa libre de las pretensiones de universalidad y progreso que caracterizaban a la novela de formación tradicional.

Los términos Bildungsroman y posmodernidad han generado polémica desde sus orígenes. Incontables estudios han intentado definir en qué consiste el género Bildungsroman y a qué se refiere el aún más problemático vocablo Posmodernismo. En su mayoría, dichos estudios manifiestan cierta inconformidad con el uso de ambos términos y con la serie de características que suelen definirlos. Utilizar estos términos en 
el estudio de novelas femeninas en la literatura contemporánea latinoamericana requiere una explicación histórico-teórica preliminar.

Numerosos estudios del Bildungsroman tradicional coinciden en otorgar a Los años de aprendizaje de Wilhelm Meister (1795) ${ }^{1}$ de Johann Wolfgang von Göethe calidad de novela fundacional del género. Es la obra prototípica donde quedan establecidos muchos de los rasgos definitorios de la novela de formación. A grandes rasgos el género puede definirse como una narración que muestra, con un enfoque didáctico, el crecimiento moral e intelectual de un héroe representativo de cierto orden social, a medida que el personaje procura reconciliar sus motivaciones interiores con la realidad del mundo que lo rodea ${ }^{2}$. Se trata de un individuo que conserva, por encima de todo, la voluntad de formarse, con la finalidad de armonizar su yo ideal con las oportunidades que le ofrece la sociedad.

Como explica Marianne Hirsch, la novela de formación que surge hacia finales del siglo XVIII y principios del XIX adopta elementos temáticos y estructurales de la novela picaresca y la novela de confesión. Ambos se pueden considerar precursores del Bildungsroman de Göethe puesto que se centran en el desarrollo de un solo protagonista, aunque hay que notar algunas diferencias significativas entre los tres modelos narrativos.

\footnotetext{
${ }^{1}$ Según Franco Moretti el Bildungsroman clásico (en que solo incluye Los años de aprendizaje de Wilhelm Meister, de Göethe y Orgullo y prejuicio de Jane Austen) se limita a las fechas de 1789 a 1815 asegurando que a partir del período posrevolucionario se transforma radicalmente la manera de representar la interioridad del héroe de la novela de formación. (Moretti, 75)

${ }^{2}$ En su Teoría de la novela Georg Lukács define el Bildungsroman de Göethe como la reconciliación del individuo problemático y su realidad, "a reconciliation between interiority and reality” (132).
} 
Hirsch propone que la diferencia fundamental entre la picaresca y la novela de formación es que en la picaresca el protagonista es un individuo marginado de la sociedad, a su vez que el texto enfoca aspectos de la vida material. Por otra parte, en la novela de confesión el protagonista es un "spiritual outsider”, mientras que la narración se enfoca en la interioridad del protagonista. En el Bildungsroman, en cambio, el personaje es un individuo representativo de la sociedad y la novela mantiene un equilibrio entre lo social y lo personal (299).

De acuerdo con el estudio de Jerome Buckley, Season of Youth, el héroe del Bildungsroman es típicamente un joven de provincia que muestra cierto descontento hacia su entorno a una temprana edad. Sus inquietudes intelectuales lo llevan a desplazarse a la ciudad para formarse en la escuela de la experiencia urbana. Allí desarrolla su vocación y madura tanto intelectual como sentimentalmente luego de haber padecido desilusiones amorosas (generalmente dos) que lo obligan a reevaluar sus principios morales. Finalmente, puede regresar a casa habiendo encontrado cierto equilibrio entre las exigencias del mundo moderno y sus deseos individuales. No obstante, según admite el propio Buckley y han reiterado otros estudios, pocas novelas de formación siguen al pie de la letra dicho patrón. Ello será especialmente cierto, como veremos más adelante, en la novela de formación femenina en general, y en la novela femenina de formación mexicana en particular.

En su mayoría, los críticos de la novela de formación tradicional distinguen entre al menos dos manifestaciones del género, aunque la ubicación de las variantes nacionales en una u otra categoría continúa siendo polémica. Por una parte se presenta el 
Bildungsroman que culmina en la plena integración del individuo y su realidad social ${ }^{3}$. Por otro lado surge la novela de formación en la que el héroe es incapaz de dar solución a la problemática individuo-sociedad a la que se enfrenta, de modo que la anhelada trayectoria formativa deriva en un proceso de desilusión. Para Marianne Hirsch esta imposibilidad de integración se da sobre todo en el Bildungsroman francés e inglés, puesto que en ambas sociedades "the human is reduced and shattered by the dominant capitalist and materialist forces”, mientras que en Alemania la novela de formación mira hacia el interior del héroe mucho más que hacia sus circunstancias externas, hecho que exalta la capacidad del individuo de ajustarse a su sociedad (309). En ambas variantes, sin embargo, predomina la expectativa esencialista de lo que constituye alcanzar la plenitud formativa. El propósito de la novela de formación del XIX se advierte en su enfoque pedagógico, que consiste en ofrecer al lector una trayectoria de vida que puede o no ser deseable, pero que en cualquier caso aporta una enseñanza formativa.

La teoría de Franco Moretti, presentada en The Way of the World, interpreta el surgimiento del Bildungsroman como una representación simbólica de las tensiones histórico-intelectuales de la Europa de finales del siglo XVIII y principios del XIX. Arguye que la novela de formación clásica es una respuesta al desafío ideológico que supuso la Revolución francesa. Moretti afirma que la representación del desarrollo psíquico del joven héroe en su proceso de formación era incompatible con el espíritu revolucionario, puesto que el héroe del Bildungsroman tradicional aboga por la

\footnotetext{
${ }^{3}$ A esta variante del género (que para Franco Moretti incluye particularmente la novela de formación inglesa [p.189] y para Marianne Hirsch la alemana [p.308] se le ha calificado de "fairy tale" o cuento de hadas debido a su invariable final feliz.
} 
transigencia entre los ideales sociales e individuales. Por consiguiente, "in the classical Bildungsroman we find the opposite of what occurred in the summer of 1789: not a secession, but rather a convergence” (64). Es decir, el héroe típico del que habla Moretti no aboga por un espíritu revolucionario sino que cifra su significado en el ímpetu conciliatorio. Para el crítico, tanto Göethe como Austen representan un proceso formativo que, si bien es conflictivo en principio, puede y debe resolverse sin llegar a ser revolucionario u ocasionar rupturas intelectuales definitivas entre el individuo y su entorno social. Según su estudio, la novela de formación puede interpretarse como un texto pacifista dado que:

the classical Bildungsroman narrates 'how the French Revolution could have been avoided'. Not by chance is it a genre that developed in Germany -where the revolution never had any chance of success -and in England - where, concluded over a century earlier, it had opened the way to a social symbiosis that renewed itself with particular effectiveness at the turn of the eighteenth century. (64)

El enfoque temático de esta nueva forma narrativa es el acomodo, un arreglo simbólico del espíritu conciliatorio que surge a partir de la crisis que inaugura la modernidad. La inexperiencia que personifican los héroes del Bildungsroman tradicional corresponde a la inestabilidad de la Europa posrevolucionaria, de manera que la figura simbólica del joven burgués, como propone Moretti, representa la propia formación y entrada de la vieja Europa a la modernidad. Dos siglos antes, Cervantes subrayaba el anacronismo que suponía la presencia del héroe caballeresco en las obras de la España del siglo diecisiete, dando protagonismo a individuos de a pie en sus obras y abriéndoles 
paso en el panorama de la literatura europea. Con Wilhelm Meister, Göethe marca el origen del héroe cuya cualidad distintiva es, por sobre todas las cosas, su juventud. Tanto el Wilhelm Meister como Orgullo y prejuicio pretenden solucionar los conflictos propios de la emergente conciencia burguesa. Ambas obras ponen a prueba la posibilidad de desarrollarse gradualmente, dejando atrás el impulso adolescente y evitando una ruptura psicológica entre las fuerzas del yo y las exigencias sociales.

El héroe de la novela de formación, en ésta y las subsiguientes etapas del desarrollo del género, se plantea una utopía, ya que de alguna manera cree en un proceso íntegro de formación. De su éxito en satisfacer tal ideal dependerá el triunfo o el fracaso del desenlace narrativo. Con la obra de Göethe nace el héroe de la novela de formación representación simbólica del despertar de una nueva sociedad cuyo desenvolvimiento llega a su máxima expresión en el género de la novela realista ${ }^{4}$. Refiriéndose a Wilhelm Meister, Mijaíl Bajtín explica la novedad narrativa que supone ocuparse de un individuo en su proceso de formación y conceder a ese hecho protagonismo absoluto - "It is no longer man's own private affair. He emerges along with the world and he reflects the historical emergence of the world itself [...] what is happening here is precisely the emergence of a new man” (23). El héroe del Bildungsroman tradicional representa primeramente la formación de una identidad pública en la que implantar los valores de la modernidad. Su propósito no es únicamente llegar a sentirse satisfecho consigo mismo sino acoger genuinamente los valores ilustrados de su sociedad. Como ha explicado Moretti, la problemática que procura resolver la novela de formación decimonónica es la

\footnotetext{
${ }^{4}$ Véase The Bildungsroman and its Significance in the History of Realism de M. Bakhtin
} 
tensión entre las exigencias de la adultez y las ansias de juventud del protagonista ${ }^{5}$. Para el héroe del primer Bildungsroman la inserción dentro de la sociedad, luego del viaje formativo, puede catalogarse de exitosa; el recorrido que lo ha conducido a la formación plena de su carácter concluye con la síntesis armoniosa de su entidad pública y privada. ${ }^{6}$

En el estudio "The Novel of Formation as Genre: Between Great Expectations and Lost Illusions” Marianne Hirsch organiza su análisis de la novela de formación en base a la distinción temática y estructural que se da en Alemania en oposición a las variantes del género en Francia e Inglaterra. En Alemania puede hablarse de una representación exitosa del proceso de formación puesto que el crecimiento moral de los protagonistas "culminates in accomodation" (302). En cambio, en Francia e Inglaterra los héroes del Bildungsroman irremediablemente padecen el desengaño de vivir en “a profoundly corrupt society [where] reality can never measure up to the imaginative richess of the heroes’ ideals” (302). Según Hirsch, la mentalidad organicista de Göethe le permite plantearse una novela de formación en base a una secuencia de eventos que culminan en la integración total y armoniosa del héroe en su sociedad. En cambio Stendhal, Balzac, Flaubert y Dickens tienden a representar las trabas sociales que imposibilitan tal progreso formativo. La trayectoria formativa de sus protagonistas,

\footnotetext{
${ }^{5}$ De acuerdo con Moretti "Maturity and youth are inversely proportional: the culture that emphasizes the first devalues the second, and vice versa... Our world calls for their coexistence, however difficult; and it therefore also calls for a cultural mechanism capable of representing, exploring and testing that coexistence” (9).

${ }^{6}$ La referencia al "primer bildungsroman" alude a la categoría que presenta Moretti en The Way of the World. Se refiere a las obras de Göethe y Austen exclusivamente puesto que según su argumento los héroes del Bildungsroman posterior (de Stendhal y Pushkin) no maduran nunca mientras que para los héroes de Balzac y Flaubert madurar significa la pérdida dolorosa de las ilusiones de la juventud.
} 
concluye Hirsch, es una representación del fracaso del individuo en una sociedad que termina devorándolo.

En las novelas de formación femenina, además de las tensiones psicosociales (individuo-sociedad) que enmarcan el Bildungsroman tradicional, se presentan las limitaciones particulares de la experiencia femenina. En su estudio, “The Novel of Awakening”, Susan J. Rosowski concluye que a diferencia del Bildungsroman masculino, en el femenino las protagonistas progresivamente reconocen que la sociedad no les ha dejado espacio para la plena realización de su individualidad. Según Rosowski, "the protagonists’s growth results typically not with an "art of living," as for her male counterpart, but instead with a realization that for a woman such an art of living is difficult or impossible: it is an awakening to limitations” (313). Para las protagonistas de Madame Bovary (1856) de Flaubert y The Awakening (1899) de Kate Chopin, el intento de expresar una interioridad reprochable culmina en la aniquilación de sí mismas. Se recurre, asimismo, al suicidio como única alternativa narrativa ante el aislamiento desgarrador que padecen.

En la colección de artículos The Voyage In, Elizabeth Abel, Marianne Hirsch y Elizabeth Langland alegan que las definiciones del Bildungsroman masculino resultan insuficientes para entender las representaciones de formación femenina. Arguyen que una minoría de obras representativas siquiera se aproximan a la definición de Jerome Buckley, concluyendo que "even the broadest definitions of the Bildungsroman presuppose a range of social options available only to men” (7). Abel subraya que las experiencias formativas a disposición de los protagonistas masculinos no son alternativas aceptables en las heroínas del Bildungsroman femenino. Esto se debe a que típicamente 
la mujer carece de los recursos económicos necesarios para desplazarse a la ciudad y aun cuando lo hacen "they are not free to explore; more frequently, they merely exchange one domestic sphere for another” (Abel 8). Refiriéndose a la definición de Buckley, Abel recalca que la experimentación sexual se representa de maneras completamente diferentes en las novelas de protagonistas femeninas. Asegura que "although adulterous relationships may offer nineteenth-century heroines brief escapes from the constraints of marriage and family obligations, this option also guarantees punishment” (8).

Hacia principios y mediados del siglo XX la novela de formación se nutre de las corrientes intelectuales del momento, en especial del existencialismo. Con las obras de Sartre las décadas de los cuarenta y cincuenta se destacan como el momento cumbre de la filosofía existencial aunque la problemática que plantea estaba prefigurada en los textos de Nietzsche. Con el alegato fundamental de que la realidad tal y como la percibimos es una ilusión en constante estado de cambio, los filósofos existenciales desarrollan un modo de pensamiento que influye significativamente en el posestructuralismo y la posmodernidad. En las obras de D.H. Lawerence, James Joyce, Virgina Woolf, Herman Hesse, y Harper Lee tenemos indicios de las nuevas angustias y retos existenciales que se plantean los escritores de la época, herederos de dicha corriente filosófica.

De manera similar a lo que propone Moretti en su estudio del Bildungsroman, en Reconstructing Childhood, Julia Kushigian estudia la novela de formación en Hispanoamérica y propone una relectura de novelas representativas basándose en las corrientes histórico-culturales del continente. Según Kushigian su enfoque en el proceso de formación individual se complementa con "the equally powerful social movements of discovery taking place in Spanish America, particularly from the period of Independence 
to the present” (220). Su teoría se apoya en el estudio clásico de Doris Sommer, Foundational Fictions: The National Romances of Latin America ${ }^{7}$ al proponer que el desarrollo del Bildungsroman hispanoamericano es una manifestación de la formación de las también jóvenes naciones de América Latina.

En Hispanoamérica, las últimas décadas del siglo XX se han denominado como “boom femenino” o “bloom” femenino (Naula Finnegan 1-2). Entre las autoras que constituyen este período de producción literaria generalmente se incluyen a Carmen Boullosa, Brianda Domecq, Ángeles Mastretta, Diamela Eltit e Isabel Allende, entre otras. Sin embargo, conviene mencionar que desde principios y mediados del siglo XX otras escritoras hispanoamericanas le habían otorgado protagonismo a los asuntos femeninos y, en gran medida, facilitaron el éxito profesional de las escritoras de finales del siglo. María Teresa de la Parra, María Luisa Bombal, Alfonsina Storni, Delmira Agustini, Dulce María Loynaz, Rosario Castellanos y Elena Poniatowska son algunas de las escritoras que fueron asentando las bases de la literatura femenina y feminista de finales de siglo XX en América Latina.

En cuanto a la conocida problemática en torno al significado y alcance teórico del concepto (o conceptos) de la posmodernidad, es pertinente señalar que una de las fuentes fundamentales del problema proviene del desacuerdo en cuanto al uso de los términos posmodernidad y posmodernismo. El Diccionario de la Real Academia Española define posmodernidad como el “movimiento artístico y cultural de fines del siglo XX, caracterizado por su oposición al racionalismo y por su culto predominante de las formas,

\footnotetext{
${ }^{7}$ Sommer, Doris. Foundational Fictions: The National Romances of Latin America. Berkeley: University of California Press, 1991. Print.
} 
el individualismo y la falta de compromiso social”. Posmodernismo, en cambio, se refiere al "movimiento cultural que, originado en la arquitectura, se ha extendido a otros ámbitos del arte y de la cultura del siglo XX, y se opone al funcionalismo y al racionalismo modernos”. No obstante, es fácil encontrar textos críticos que utilizan ambos términos de manera imprecisa, lo cual puede generar confusión, particularmente en lo que se refiere a su uso en la crítica literaria latinoamericana ${ }^{8}$.

En La condición posmoderna: Informe sobre el saber (1979) Lyotard propone una actitud escéptica hacia los grandes discursos que legitiman el conocimiento. En las sociedades que denomina "posindustriales” o “más desarrolladas” asegura que se ha perdido la fe en el conocimiento fijo y absoluto a raíz de los avances tecnológicos de las últimas décadas. Para la segunda mitad del siglo XX la moral y la mentalidad burguesas que habían sostenido los discursos hegemónicos de la modernidad quedan desbancados. Según Lyotard, la posmodernidad se caracteriza por su "incredulidad con respecto a los metarrelatos” refiriéndose particularmente a los discursos legitimadores ilustrados que planteaban un beneficioso progreso universal (4). En Defining the Postmodern, publicado en 1986, Lyotard alude al paulatino declive de la idea del progreso y lo que denomina "the failure of the modern project" $\left(1935^{9}\right)$. Después de dos guerras mundiales, la fe en

\footnotetext{
${ }^{8}$ El uso del término posmodernismo generalmente se refiere al período sucesivo al movimiento literario predominantemente anglosajón de comienzos del siglo XX llamado Modernism, el cual no debe confundirse con el modernismo latinoamericano correspondiente a las últimas décadas del siglo XIX. Oviedo ha señalado que en la historiografía hispanoamericana, las vanguardias coinciden con el Modernism anglosajón (véase Oviedo vol. 4, pg. 384).

${ }^{9}$ Véase el texto en su totalidad en The Critical Tradition: Classic Texts and Contemporary Trends, [p. 1933-1935].
} 
el progreso y el perfeccionamiento de la sociedad que promulgara la Ilustración pierden credibilidad epistémica y se empieza a sospechar de los grandes discursos o explicaciones totalizantes que sujetaban dicho proyecto de la modernidad.

Los textos críticos acerca de las teorías de la posmodernidad de las décadas de los ochenta y noventa invariablemente sugerían inconformidad con todo acercamiento posible al término. En Postmodernist Fiction, Brian McHale problematiza el término explicando que posmodernismo carece de sentido: "the term does not even make sense. For if 'modern' means 'pertaining to the present,' then 'postmodern' can only mean 'pertaining to the future,' and in that case what could postmodernist fiction be except fiction that has not yet been written?” (4). Alega que posmodernismo denota el carácter histórico del fenómeno literario; y por tanto no se refiere a lo posterior a lo moderno, sino a lo posterior al movimiento modernista anglosajón de comienzos del siglo veinte. El crítico no cree que el modernismo haya concluido y que por lo tanto el posmodernismo es el siguiente -ismo. Entiende el posmodernismo como una continuación o consecuencia histórica del modernismo, al cual nos acercamos con una nueva perspectiva. McHale explica la transición entre modernismo y posmodernismo en relación al surgimiento de “the dominat" ${ }^{10}$ que puede tener un carácter epistemológico u ontológico y que puede entenderse como el aparato de enfoque que rige un texto ${ }^{11}$. Como regla general, propone McHale, la obra de arte modernista se caracteriza su carácter epistemológico mientras

\footnotetext{
${ }^{10}$ El concepto de "el dominante" proviene del formalismo ruso, particularmente de Viktor Schklovsky y Roman Jackobson.

${ }^{11}$ Jackobson define el concepto de "el dominante como "the focusing component of a work of art: it rules, determines and transforms the remainder components" (Raman Selden 38).
} 
que en la posmodernista predomina el elemento ontológico. En otras palabras, si el proceder epistemológico se pregunta cómo llegar a conocer la realidad, el pensamiento ontológico se cuestiona cuál realidad.

Linda Hutcheon, por su parte, concuerda con otros críticos en que el posmodernismo es una continuidad del modernismo más que una reacción. El arte posmoderno incorpora, del modernismo, la tendencia autorreflexiva y la crítica a determinados valores totalizantes de la Ilustración. No obstante, Hutcheon propone que una importante cualidad distintiva del arte posmodernista radica en su rechazo al elitismo modernista. Según Hutcheon, el posmodernismo utiliza la parodia para lidiar con su inherente carácter contradictorio -la complicidad y la crítica. La parodia, asegura en A poetics of Postmodernism, "is a perfect postmodern form...for it paradoxically both incorporates and challenges that which it parodies” (11). Partiendo de su análisis, el posmodernismo, entonces, también se ocupa de revisitar y cuestionar los relatos magisteriales dominantes, no desde los márgenes, sino desde sus mismos ejes significativos. Para Hutcheon la cultura posmoderna no es simplemente una negación del discurso dominante sino más bien un cuestionamiento desde sus propios presupuestos (6). Hacia finales del siglo veinte, podemos decir que se alcanza cierto consenso en cuanto a algunos parámetros característicos. En Postmodernism and the Contemporary Novel, Brian Nicol sugiere que se ha llegado a cierto acuerdo en cuanto al uso del término posmodernismo y que para el comienzo del siglo veintiuno ya puede hablarse de una definición más o menos satisfactoria del término. De acuerdo con Nicol, “postmodernism can be regarded as a mode of cultural awareness informed by the conviction that everything is, in fact, cultural; that is, nothing in life - nationalism, value 
systems, identity, history, even reality - is natural or given ... everything is constructed, mediated, put there by someone for a particular reason” (3). Es decir, al hablar de posmodernidad debemos al menos coincidir en que se refiere a una sensibilidad filosófica que propone una reevaluación de los discursos esencialistas y hegemónicos de la modernidad.

Zygmunt Bauman, quien ha denominado a la modernidad "the project of domination” propone que las inquietudes que se plantea la posmodernidad poseen un potencial liberador. En su ensayo Postmodernity or Living with Ambivalence, Bauman arguye que la posmodernidad se significa en el reconocimiento de que:

the growth of knowledge expands the field of ignorance, that with each step to the horizon new unknown lands appear, and that... acquisition of knowledge cannot express itself in any other form but awareness of more ignorance. To face up to this fact means to know that the journey has no clear destination -and yet persevere in the travel. (23)

Aquí Bauman coincide con el pensamiento de Lyotard en cuanto a la sospecha hacía los metarrelatos legitimadores del conocimiento impuestos por el discurso científico. El objetivo del sociólogo es argüir que la posmodernidad puede entenderse como una oportunidad redentora, un camino filosófico hacia la inclusión, la tolerancia y, esperemos, la solidaridad. Asegura que "living in contingency means living without a guarantee, with just a provisional, pragmatic, Phyrhonic, until-further-notice certainty, and this includes the emancipatory effect of solidarity” (15). Al abandonar el lenguaje de la modernidad, que él entiende es el lenguaje de la humillación del otro, podemos aspirar a un lenguaje de inclusión y solidaridad hacia los que tradicionalmente han sido 
marginados e invisibilizados por los grandes discursos de progreso, orden, y perfectibilidad humanos.

Las aspiraciones de inclusión posmodernas se centran también en el problematizar la hegemonía cultural europea. Si bien la modernidad se dedicó a crear referentes estéticos en la arquitectura, la pintura, y la literatura; la posmodernidad hace hincapié en el valor de descentralizar tales presupuestos. Y no solo en lo referente a las artes, también notamos un marcado interés en reevaluar el pensamiento político y especialmente la expansión del capitalismo ${ }^{12}$. Esta tarea de replantearse la contemporaneidad ha tenido como consecuencia la descentralización de los valores absolutos del proyecto de la modernidad, lo cual le ha abierto las puertas y otorgado legitimidad a otros modos narrativos y espacios literarios. Hispanoamérica es una de las localidades narrativas que se benefician de la pluralidad y del objetivo descentralizador de la filosofía posmoderna. Según propone George Yúdice la posmodernidad se refiere a una "condición en la cual se está representando lo que ha sido la modernidad, condición en la cual nos damos cuenta de que ha habido varias modernidades” (111). Yúdice sugiere que la heterogeneidad cultural latinoamericana en el contexto revisionista de la posmodernidad genera la “construcción de un imaginario democratizador” en la que el diálogo y el intercambio ideológico no tienen fin sino que se siguen representando y rearticulando (128).

Así como Yúdice enfoca su análisis en la pluralidad inherente en la formación de Latinoamérica y sus consecuencias, Néstor García Canclini subraya la problemática de la

\footnotetext{
${ }^{12}$ Aunque el enfoque de la crítica posmoderna va dirigido al capitalismo por su naturaleza hegemónica, algunos críticos de la posmodernidad como Lyotard señalan, asimismo, el carácter totalizante marxista.
} 
importación al continente latinoamericano de ideologías y modelos, coherentes dentro de la modernidad europea. Propone Canclini que:

La modernidad es vista entonces como una máscara. Un simulacro urdido por las élites y los aparatos estatales, sobre todo los que se ocupan del arte y la cultura, pero que por lo mismo los vuelve irrepresentativos e inverosímiles. Las oligarquías liberales de a fines del siglo XIX y principios del XX habrían hecho como que constituían Estados, pero sólo ordenaron algunas áreas para promover un desarrollo subordinado e inconsciente, hicieron como que formaban culturas nacionales, y apenas construyeron culturas de élites dejando fuera a enormes poblaciones indígenas y campesinas que evidencian su exclusión en mil revueltas y en la migración que trastorna las ciudades. (20-21)

Por su parte, Brian McHale explica que "Latin America is a mosaic of dissimilar and, on the face of it, incompatible cultures, languages, world-views, landscapes, ecological zones. Its condition is, we might say intrinsically postmodernist” (52). Yúdice había argumentado anteriormente que tal "heterogeneidad podría hacer pensar que América Latina era ya posmoderna antes que Europa y Estados Unidos”, sugiriendo con un enfoque revisionista una aceptación de modernidades múltiples (107). Es decir, hablar de posmodernidad en América Latina primeramente supone reconocer que el fenómeno que se ha denomidado modernidad ha sido múltiple y ha tenido variadas manifestaciones en las sociedades latinoamericanas que no se ciñen al esquema generado por la modernidad en sus orígenes europeos. 
El vínculo crítico entre el Bildungsroman actual de las narradoras que nos ocupan y la sensibilidad posmoderna deriva de la conexión establecida por Moretti entre el Bildungsroman clásico y la modernidad. En las muestras contemporáneas que serán estudiadas aquí, se expondrá como el modelo de la novela de formación se ha adaptado en América Latina para representar el espíritu hipercrítico de la posmodernidad. La novela de formación tradicional cree, por decirlo así, en un período crítico de formación. En cambio, su variante posmoderna postula que toda experiencia es formativa; la madurez se entiende como un proceso fluido y no un fin en sí mismo. No hay una fase ideal después de la cual cesa dicha experiencia formativa. En otras palabras, la relación problemática entre la interioridad de los personajes y las exigencias sociales no finaliza a una edad particular; no hay un plazo predeterminado para alcanzar, exitosamente o no, la ansiada madurez que procuraba el Bildungsroman decimonónico.

En la novela de formación tradicional, dado el contexto histórico que las sostiene, predomina un interés pedagógico y conciliatorio que presupone un “progreso” psíquico en protagonistas que finalmente alcanzan cierta aceptación o integración social. Si bien el apogeo de la novela de formación se ha interpretado como una consecuencia históricointelectual del proyecto de la modernidad, con la posmodernidad podemos conceptualizar los rasgos del Bildungsroman posmoderno, particularmente los modelos femeninos, al enfocar como muestras representativas las variantes de Mastretta y Boullosa. Si bien la modernidad se afinca en un género narrativo particular (que es el Bildungsroman), las particularidades discursivas de la posmodernidad dan lugar a una reevaluación del género clásico, ofreciendo una posibilidad narrativa posmoderna del mismo. Según explica Simon Malpas: "With the destruction of the grand narratives, there is no longer any 
unifying identity for the subject or society. Instead individuals are the sites where ranges of conflicting moral and political codes intersect, and the social bond is fragmented" (29). De ahí que la hibridez y la ambigüedad se conviertan en características fundamentales de los personajes posmodernos de las novelas de las que se ocupa el presente trabajo.

Teniendo en cuenta el período de la literatura posnacional en Hispanoamérica, hay que señalar las implicaciones sociológicas del bildung posmoderno en el contexto hispanoamericano. Hacia la segunda mitad del siglo XX la producción literaria hispanoamericana se aparta de las tendencias esencialistas que pretendían explicar la totalidad de la experiencia hispánica en América Latina. Así como en Alemania, Francia e Inglaterra el Bildungsroman como subgénero literario desempeñó una función social, convirtiéndose en el modelo predilecto para representar la formación e integración del protagonista en su sociedad, en Hispanoamérica, el Bildungsroman posmoderno igualmente responde a un enfoque social en particular. En las naciones europeas la novela de formación difundió un modelo pedagógico a través del proceso de maduración de un individuo representativo de una sociedad anclada en los ideales de modernidad. En Hispanoamérica, dado el contexto histórico-social y filosófico que genera el fenómeno de la globalización y el desgaste de los relatos magisteriales, la novela de formación rechaza la representación convencional y esencialista de la identidad del personaje protagónico. Los personajes protagónicos del Bildungsroman posmoderno hispanoamericano, de hecho, se resisten a las categorizaciones totalizantes; no responden a un proyecto social coherente con pretensiones de universalidad. Se trata pues de protagonistas que visibilizan y dan voz a figuras femeninas que, de otro modo, quedarían excluidas de los discursos predominantes, en términos no solo narrativos sino también sociales. 
Los textos de Mastretta y Boullosa seleccionados para este estudio representan un cambio de perspectiva a la hora de narrar la experiencia formativa femenina. Si bien los Bildungsroman de ambas escritoras heredan rasgos narrativos de la larga tradición del género en Europa y sus variantes americanas, sus obras se distinguen en tanto y en cuanto optan por un paradigma discursivo radicalmente distinto. Los capítulos siguientes pretenden explicar el vínculo entre la renovación del Bildungsroman de Mastretta y Boullosa y el marco teórico que difundió la posmodernidad. Las protagonistas de estos textos, aunque de modos muy diversos, no puede decirse que sigan el patrón formativo al que se ciñe la novela de formación tradicional. Más bien, las narradoras mexicanas reconstruyen un proceso formativo que prescinde de la representación idealizada de la juventud como un camino que conduce progresivamente a una madurez definitiva. Tanto Mastretta como Boullosa proponen una revaloración de los discursos hegemónicos de la modernidad en sus manifestaciones narrativas. 
CAPÍTULO 1: ARRÁNCAME LA VIDA (1985)

\subsection{PROBLEMÁTICA FEMENINA Y FEMINISMO: (RE)VISIONES DEL MODELO CLÁSICO DE LA NOVELA DE FORMACIÓN}

Nacida en la ciudad de Puebla, Ángeles Mastretta se adentra al mundo de las letras y la escritura a través del periodismo. Luego de graduarse de dicha profesión colabora para publicaciones como Excélsior, Ovaciones y La Jornada. Además, formó parte del consejo editorial de las revistas NEXOS y FEM ${ }^{13}$. Según asegura la propia Mastretta, el descubrimiento de su vocación de escritora ocurre mientras ejercía el periodismo. En su entrevista con Kay S. Garía, Mastretta explica:

After struggling with doubts, I have discovered that I am a novelist because I love to add details to reality... besides I have a family that is very apt at telling stories and that has rubbed off on me... I soon realized that I couldn't be a news writer like other journalists because I always made up my journalism assignments. We were told, "Do an interview with a politician,” and everybody went to interview a local representative and I interviewed the president of the Republic. Then the professor said, "What a prodigious interview! How did you do it?” and I knew that my story was a lie... It was then that I realized that I had to devote my time to inventing... (72)

En el ámbito literario, Arráncame la vida (1985) fue su primera publicación, la cual se ha traducido a doce idiomas y recibió el premio literario Mazatlán en 1986. Su segunda novela, Mal de amores (1995), también obtuvo buena recepción por parte de la crítica y

\footnotetext{
${ }^{13}$ FEM es una revista feminista fundada en México en 1976.
} 
alcanzó el premio Rómulo Gallegos en 1997. Desde entonces, Mastretta ha compartido su labor de escritora entre la redacción periodística y la de ficción, aunque priorizando su labor de narradora.

La crítica de Arráncame la vida ha mostrado una tendencia casi absoluta al análisis de la novela de Ángeles Mastretta a partir de las teorías feministas como único trasfondo crítico pertinente. Sin embargo, estos caminos críticos, aunque han aportado interpretaciones significativas, a menudo generan un dilema que limita las posibilidades de estudio de la novela. Abundan estudios que proponen que la novela es un texto feminista así como también los que concluyen que no lo es. Algunos críticos aseguran que se trata de una novela feminista donde el personaje protagónico desempeña una función subversiva y que al final se las arregla para encontrar una identidad propia dentro de la sociedad patriarcal. De acuerdo con Nadia Dolores Avedaño, Arráncame la vida es "representative of a feminist version of the Bildungsroman" (9). Jane Elizabeth Lavery, refiriéndose a la autora, afirma que "as a fervent feminist she is keen to make her books accesible”, y arguye que, en efecto, su literatura no presume de "philosophical and technical game-playing” (7). En cambio, en otros estudios la interpretación que se le da a la heroína de Mastretta es la de una mujer ingenua y pasiva sometida al yugo del marido sanguinario. Según Alice Edwards:

for all of Catalina's strength, intelligence, and resistance, she fails in any profound way to establish an identity and a life for herself that is not predicated on that of her husband. Her life story is one of passivity, and while it is occasionally interrupted by flights into romance and brief 
rebellions, Catalina does not and perhaps cannot, separate herself from the people and institutions that seek to constrain her energy and identity. (100)

A la hora de ubicar la obra de Mastretta, las historias de la literatura hispanoamericana la colocan dentro de capítulos que generalmente tratan la narrativa femenina del post-boom. A menudo se define su trabajo literario resumiendo que es una narradora feminista puesto que, ciertamente, los asuntos de índole femenina sobresalen en sus textos. No obstante, como ha explicado Elzbieta Sklodowska, refiriéndose a otras novelas femeninas del post-boom, "estas novelas -sin ser necesariamente feministas o 'propiamente femeninas’ -son fémino-céntricas; por lo cual representan una ruptura ideológica sin precedentes con el discurso dominante de las letras hispanoamericanas: masculino, patriarcal, machista, burgués” (143). Mastretta ha reiterado en más de una ocasión su relación problemática con el término feminismo. En una entrevista concedida a Kay S. García en 1994, Mastretta se resiste a que la cataloguen de feminista (a pesar de centrar sus novelas en personajes femeninos) sosteniendo que con Arráncame la vida no se proponía dar voz a una ideología feminista: “I wasn’t writing a femenist thesis, I was writing a story, and it is clear that Catalina wouldn't think of trying to transform Andrés into a supportive husband who changes diapers” (García 78-80).

En base a dicha afirmación cabe preguntarse a qué se debe el interés de Mastretta en distanciarse públicamente de la teoría feminista, reconociendo que la autora tiene una extensa trayectoria en la que participa de publicaciones y proyectos indudablemente feministas. Para entender la actitud aparentemente contradictoria de la autora es útil referirse a la recepción crítica y a la realidad publicitaria que imperan en el ámbito literario femenino. Aunque muchas "escritoras latinoamericanas suelen negar que haya 
una escritura femenina [y] muchas veces dicen que la escritura es neutral, [hay] que entender esta negación como un rechazo al encasillamiento, recordando las Historias de Literatura que metían a las mujeres en un párrafo aparte al final del capítulo” (Jean Franco 41). Mastretta concuerda con la conclusión de Franco en su entrevista con Gabriella de Beer: "I want to be considered a writer and not especifically or exclusivelly a woman writer. I want to write so that when they speak of Mexican literature in general I will be included in Mexican literature in general, and not only when they speak of Mexican literature written by women” (16). Para muchas escritoras de la época, aceptar que producen una literatura feminista es dar pie a que se les califique de escritoras light, que producen una literatura menor o poco seria. La preocupación que expresa Mastretta al respecto se justifica en la escasa atención crítica que tradicionalmente recibían las narradoras, cuyo trabajo "ha sido tratado como periférico con respecto a la literatura escrita por hombres” (Sklodowska 141).

Teniendo en cuenta que en los estudios de Arráncame la vida se ha estudiado extensamente el referente teórico feminista, se han investigado las relaciones de poder fundamentales en el texto y se ha determinado el éxito o el fracaso de la protagonista en su proceso de formación a partir del ángulo interpretativo del feminismo, resulta sorprendente que la novela no se haya investigado suficientemente a la luz del pensamiento posmoderno, cuyo auge crítico en las décadas de los ochenta y noventa aportan un marco de estudio pertinente, que además ilumina la postura problemática hacia el feminismo que tanto ha recalcado la escritora. La consabida ambigüedad de Mastretta hacia el feminismo tradicional sugiere que posiblemente sus referentes 
ideológicos descansan sobre las bases teóricas de la posmodernidad mucho más que sobre la propia ideología feminista convencional.

La tendencia a problematizar el uso y significado del término feminismo ha caracterizado a muchas escritoras posmodernas, incluyendo a Mastretta. Se puede advertir cierta correspondencia entre la inconformidad hacia el feminismo que exponen estas escritoras y la preocupación que los críticos de la posmodernidad han expresado en cuanto al fenómeno posmoderno. Si el pensamiento posmoderno genera, por definición, un estado de problematización y reflexión acerca de determinados presupuestos o metarrelatos que dábamos por hecho, la postura crítica de Mastretta hacia el feminismo resulta, en gran medida, predecible y consecuente con los principios filosóficos de esa posmodernidad siempre escéptica de rótulos totalizantes. Con dicha actitud no solo pretende evitar el encasillamiento de su labor literaria sino que además expone su descontento con los modelos esencialistas del feminismo tradicional. Según sostiene Teresa L. Ebert, "both modes of feminism -those advocating equality and those claiming difference -are what I call "identitarian” feminism because of their essentialist commitment to identity" (891). Por tanto, la marcada reticencia de Mastretta a adoptar dichos paradigmas esencialistas corresponde a la lógica posmoderna que informa su escritura. Rechaza, pues, la idea del feminismo como otro metarrelato que presume un poder hegemónico explicativo. Sus textos no pretenden consolidar ni impulsar una ideología feminista particular puesto que eso significaría suponer una cohesión universal de la experiencia femenina, idea que Mastretta no está dispuesta a apoyar.

En su primera novela, Arráncame la vida (1985), Ángeles Mastretta presenta la historia personal de Catalina Guzmán en el trasfondo histórico del México 
posrevolucionario de los años treinta y cuarenta. La narración comienza con la reflexión de la protagonista acerca del año en que se casa con el general Andrés Ascencio, cuya caracterización se basa en quien fuera el gobernador de Puebla de 1937 a 1941, Maximino Ávila Camacho ${ }^{14}$. En la retrospección inicial -“Ese año pasaron muchas cosas en este país. Entre otras Andrés y yo nos casamos” - se acentúa la preponderancia de los asuntos de índole personal dentro de un controvertido entorno político a partir de los cuales se define el perfil narrativo y reconocemos que no estamos en presencia de un Bildungsroman tradicional (7). Por una parte este comienzo nos deja con la impresión de estar leyendo el desenlace de una novela de formación más que el inicio, especialmente si nos acercamos a este texto habiendo experimentado los patrones de la novela de formación tradicional. Por otra parte, pareciera haber una voluntad autoral de restar importancia social y sentimental al enlace matrimonial entre Andrés y Catalina. El enlace oficial se presenta como uno de tantos sucesos en el transcurso de todo un año, lo cual puede hacernos pensar que fue un evento ordinario, casi un imprevisto.

En novelas de formación clásicas como Orgullo y prejuicio y David Copperfield podemos observar contrastes significativos en el enfoque de la frase inaugural ${ }^{15}$. Jane Austen alude a uno de los tópicos centrales de la modernidad refiriéndose a la búsqueda

${ }^{14}$ En su entrevista con Kay S. García, Ángeles Mastretta asegura que un noventa por ciento de la novela es ficción aunque los personajes políticos que recrea en su narración están inspirados en figuras históricas del México postrevolucionario. Monique J.

Lemaître ofrece una amplia explicación de las figuras históricas que aparecen en el texto y sus correspondientes variantes de ficción.

15 "Es una verdad mundialmente reconocida que un hombre soltero, poseedor de una gran fortuna, necesita una esposa" y "Si soy yo el héroe de mi propia vida o si cualquiera me reemplazará, lo dirán estas páginas” son las frases introductorias de Orgullo y prejuicio de y David Copperfield respectivamente. 
de certezas universales. Ésta presenta la temática del matrimonio (aunque con ironía) como una realidad "mundialmente reconocida” y esencial para "un hombre soltero” y, vale mencionar, para una mujer deseosa de cierta independencia económica ${ }^{16}$. Charles Dickens también apela a los presupuestos intelectuales de la modernidad enfatizando el concepto de individualismo. El lector de Dickens de inmediato se enfocará en la capacidad de cada individuo de ser el "héroe” de su propia vida o al menos se preguntará qué lección le proporcionará el héroe de ficción que tiene ante sus ojos. Ambos ejemplos del siglo XIX comparten desde sus respectivos inicios, el espíritu esencialista e individualista de una modernidad sustentada en consensos ideológicos. Ambas obras se inician con referencias a los valores de integración social y madurez individual que fomentaba la modernidad ${ }^{17}$.

En la novela de Mastretta, el enlace oficial entre Catalina y Andrés queda enmarcado en un tono de indiferencia, casi de resignación, lo cual no quiere decir que el tratamiento que se le da al acto del matrimonio sea insignificante. Por el contrario, el casamiento justifica la entrada de la protagonista en la sociedad y es a partir de dicho enlace que comienza la representación del proceso formativo femenino ${ }^{18}$. Se trata de un

\footnotetext{
${ }^{16}$ Según Austen "single women have a dreadful propensity for being poor, which is one very strong argument in favor of matrimony" (Jones 181).

${ }^{17}$ En este caso tales ideales se resumen en el acto del matrimonio como símbolo de la culminación de una etapa formativa y la noción de que cada ser humano debe ser héroe o maestro de su propia vida.

${ }^{18}$ Vale notar que en lo que se refiere a la institución del matrimonio, en la cultura mexicana la experiencia formativa femenina difiere de la masculina. Generalmente los hombres se casan una vez que han alcanzado cierta madurez o se consideran adultos mientras que las mujeres se consideran adultas y maduras una vez que se casan.
} 
individuo que encuentra su voz y motivo narrativo a partir del temprano vínculo matrimonial. En principio, ésta da la impresión de ser una narradora ingenua, como si careciera de profundidad reflexiva. Su aparente inercia ante los sucesos clave de su propia experiencia individual como el matrimonio y la maternidad denotan la limitada preparación psíquica con la que deberá desempeñar las responsabilidades tradicionales de una mujer casada.

En las novelas de formación tradicional, cuando se nos presenta a un protagonista apto para el matrimonio generalmente significa que éste ha alcanzado la suficiente madurez como para afrontar la responsabilidad individual y social que tal vínculo supone. Franco Moretti explica que el matrimonio en el Bildungsroman clásico coincide con la culminación del período formativo y la entrada del protagonista a la vida adulta. El matrimonio se entiende como "the end of all tension between the individual and the world”, lo cual significa que "all desire for further metamorphosis is extinguished” (23). En el caso de la heroína de Mastretta, ocurre una inversión, subversiva, de la representación tradicional del proceso de formación de las novelas europeas. El matrimonio de Catalina a los quince años de edad es, en efecto, el inicio de su toma de conciencia personal y no la culminación de una etapa de formación. Lejos de manifestar la consolidación del período de formación de la protagonista, el rito matrimonial se presenta como un suceso inevitable, dado la socialización femenina, particularmente dentro los parámetros patriarcales del contexto narrativo. Según sostiene Yolanda A. Doub, "many novels of female formation relate the Bildung of an older protagonist, whose self-cultivation was delayed by marriage” (7). Asimismo, en el caso de Catalina el enlace matrimonial por un lado pareciera una interrupción de la experiencia formativa y 
por otro funciona a modo de pretexto para iniciar un relato de formación alternativo y ambiguo que cuestiona el propio concepto de Bildungsroman.

La llegada de Andrés a la familia Guzmán pareciera suceder de manera accidental. No obstante, sabemos que Andrés siempre actúa premeditadamente ${ }^{19}$ y que la juventud e ingenuidad de Catalina, le impiden ver más allá de la “expresión de certidumbre” que la atrajo a su futuro marido (7). Andrés se propone despojarla de su inocencia y vínculos familiares, particularmente del apego que ésta tiene con su padre. De hecho, uno de los primeros intercambios entre ambas figuras masculinas es una auténtica humillación del padre de la protagonista. Durante el desayuno en el cuál la familia celebraba las nupcias, Andrés se dirige a Don Marcos para recordarle que Catalina “ya no es una niña” y le dice bruscamente - "en esta mesa mando yo" (17). Andrés sabe que el matrimonio había sido poco más que un acto de posesión y no menos que una deshonra para la familia Guzmán.

Catalina recuerda que “años después, cuando su hija Lilia se andaba queriendo casar, Andrés dijo: - ¿Piensas que yo voy a hacer con mis hijas como tu papá contigo? Ni madres. A mis hijas no se las lleva cualquier cabrón de la noche a la mañana... Y se me casan por la iglesia...” (16). Ante semejante revelación, la narradora reconoce una de las numerosas desilusiones de su vida conyugal. Sabe que Andrés le negó lo que hubiera sido un casamiento legítimo dentro de la tradición católica de la cual proviene, violentado la honra de la familia, en especial la de la figura paterna. Con el ejemplo de Lilia, años más tarde, "nos percatamos que la situación de la mujer no ha cambiado en lo esencial ya que

\footnotetext{
${ }^{19}$ Durante la descripción de su matrimonio, la narradora interviene con la siguiente afirmación: "Con los años aprendí que Andrés no decía nada por decir” (16).
} 
ésta sigue siendo, a fines de los cuarenta, una mercancía de trueque en el vasto mercado del poder patriarcal. La única diferencia estriba en que el padre de Catalina es pobre y Andrés goza de ciertos privilegios económicos; el primero nos es presentado como débil e impotente ante el evento y, el segundo, como prepotente” (Monique J. Lemaître León 105).

La relación de Catalina con su padre ha suscitado polémica entre los críticos, puesto que es el único modelo de masculinidad que ha tendido la protagonista hasta el momento del matrimonio. Para Andrés, es de particular importancia suprimir el vínculo de Catalina con su padre dado que es la única persona a quien Catalina le manifiesta un cariño auténtico e incondicional. Algunos críticos como Jane Elizabeth Lavery han expresado que "in a book of relative lovelessness, the father-daughter relationship provides a solitary example of human love” (52). Otros estudios argumentan que la estrecha relación de la protagonista con su padre posee elementos incestuosos. Kay E. Bailey propone que "Catalina tiene una relación muy especial con su padre que se puede interpretar como algo incestuoso" y concluye que aunque el "lector no sabe por cierto si hay algo incestuoso entre Catalina y su padre... estas descripciones del contacto físico abren las puertas para esta interpretación” (136). Hedy Habra, por su parte, sostiene que "la fuerza de la imagen paterna” puede representar "el incesto en potencia” (140). Sin embargo, ni Bailey ni Habra profundizan en las implicaciones de dicha hipótesis y se limitan a sugerir la posibilidad del incesto.

Dentro de la cultura mexicana no es extraño que haya proximidad física y expresiones afectivas entre padres e hijas, de manera que resulta difícil sustentar semejante acusación en base a la realidad textual. Cuando Catalina recuerda 
nostálgicamente: “me gustaba besar a mi papá y sentir que tenía ocho años...” no podemos suponer que se trate de una relación con sentimientos ocultos o incestuosos. Si tomamos en cuenta el apego que ha expresado tener la autora con su padre, posiblemente estas líneas le proporcionen una seña autobiográfica al texto de Mastretta ${ }^{20}$. En su entrevista con Gabriella de Beer, Mastretta confirma que las figuras paternas en sus libros tienen una base autobiográfica - "I had a very close relationship with my father. My image of him is fabled, mythical, and so are the fathers in my books. Catalina Asencio has a wonderful father whom she loves deeply... That is autobiographical” (234). Para Catalina, los encuentros con su padre son un modo de sobrevivir la angustia que la sobrecoge en los primeros años de su matrimonio con Andrés ${ }^{21}$. En una de sus visitas a la casa de sus padres recuerda - "Lo abracé. Me estuve un rato pegada a su cuerpo, evocando el olor del campo y sintiendo el del café. Se estaba bien ahí y me puse a llorar” (60). El contacto físico y el juego con la figura paterna cumplen una doble función, la de mitigar los efectos de la vida atormentada que lleva con Andrés y la de establecer desde el inicio que no habrá en esta novela una ruptura entre el individuo en su recorrido formativo y la figura del padre, como sí suele ocurrir en la novela de formación convencional.

\footnotetext{
${ }^{20}$ Uno de tales referentes autobiográficos de su herencia italiana por el lado paterno se puede apreciar en la visita que Catalina hace a su padre en un momento de angustia: "Fui a casa de mis padres en busca de apoyo. Mi papá estaba en la cocina esperando que su cafetera empezara a soltar un chorro de café negro... La cafetera era italiana. Se paraba frente a ella todas las mañanas a esperar su expreso como si estuviera en la barra de un café romano" (59-60).

${ }^{21}$ Esta es la etapa en que llegan a oídos de Catalina los rumores de "los ochocientos crímenes y las cincuenta amantes del gobernador” (56).
} 
Con la muerte del padre queda claro que Catalina ha perdido una fuente de apoyo sentimental indispensable. La ruptura del vínculo físico con quien fuera su principal modelo formativo la obliga a replantearse su identidad a un nivel tanto público como personal. Es la única ocasión en toda la novela que llora “en público como nunca debió hacerlo la esposa del gobernador” (110). Más adelante, presenciando un concierto de Carlos Vives, la sobrecoge la falta del padre y sostiene: “y yo como siempre que él estaba sin estar... me puse a llorar hipeando y moqueando hasta hacer tanto ruido como la orquesta” (139). Hay que puntualizar que no muestra señas semejantes de tan profunda tristeza ni con el asesinato de su amante, Vives, ni con la sospechosa muerte (posible homicidio) de Andrés.

Lo que sí queda claro es que Catalina demuestra una fuerte preferencia afectiva hacia la figura paterna, mientras que la relación con su madre tiende a ser más fría. Catalina mantiene una relación distante con su madre y nunca la menciona de manera afectuosa, sino como contrapunto a su propia personalidad. Luego que Andrés decide casarse con ella, Catalina recuerda como su madre se puso a llorar y asegura que le "dio gusto porque le ponía algo de rito a la situación”. Luego interviene en tono despectivo, reprochando que su "mamá se la pasaba presintiendo" (14). A Catalina las sensibilidades de su madre le son indiferentes, como si deliberadamente pretendiera distanciarse de ésta, favoreciendo emocionalmente a la figura paterna. Sabemos que ella se compadece del padre cuando éste se muestra sentimental o en los momentos en que Andrés lo humilla. En cambio, Catalina muestra muy poco apego hacia su madre y la asocia, negativamente, con la imagen de la mujer tradicional latinoamericana. 
Podemos observar que su tono en los capítulos iniciales es excesivamente ingenuo y hasta infantil, lo cual sugiere una intención autoral de caracterización. Catalina aparentemente ha sido una niña mimada y sobreprotegida. En cierta medida, el punto de vista ingenuo es una constante a través del texto, aunque con ligeros ajustes que favorecen la verosimilitud de la voz narrativa en diversas etapas de formación. En ocasiones, la marcada ingenuidad de Catalina produce lástima ya que reconocemos en su experiencia formativa indicios de ciertos desajustes psicológicos en lo referente a las expectativas de “madurez” según la edad del adolescente. Según explica Lavery, Catalina "acts and speaks like a child... acts on impulse, and experiences childish tantrums" (61). Durante la ceremonia de su matrimonio, ésta insiste en que sus hermanos pequeños firmen el registro de testigos. "Pero yo quiero que firmen... ellos son los que juegan conmigo”, arguye en esta frase, que aunque poco verosímil, nos recuerda que se está casando siendo una niña (15). No obstante, vale aclarar que no era inusual en el contexto histórico de la novela que se casara una chica a la edad de Catalina ni tampoco que el esposo le duplicara la edad.

\subsection{REPRESENTACIONES POSMODERNAS DE FORMACIÓN FEMENINA}

La posmodernidad, entre otras cosas, invalidó los procesos de categorizaciones culturales que había erigido la modernidad. Hablar de la novela de formación femenina en la posmodernidad necesariamente implica una redefinición de términos. La característica incredulidad hacia los grandes discursos de la que habla Lyotard genera asimismo la reevaluación de uno de los géneros predilectos de la modernidad. En el 
primer Bildungsroman de Mastretta la representación del proceso formativo femenino incorpora el discurso posmoderno de fragmentación, incredulidad y pluralidad, lo cual provoca en consecuencia, que el texto de la escritora mexicana manifieste la voluntad de disentir de las categorías totalizantes asociadas con la novela de formación decimonónica, la cual está profundamente arraigada en los postulados de progreso y formación individual de la modernidad.

Uno de los legados fundamentales de la modernidad puede explicarse en base a la difusión de un renovado concepto de individualidad e individualismo. De acuerdo con lo que propone Frederic Jameson, "the great modernisms were [...] predicated on the invention of a personal, private style, as unmistakable as your fingertip, as incomparable as your own body” (1958). Según el criterio de Jameson, en la posmodernidad no hay cabida para el concepto del individuo único; asegura que para algunos "not only is the bourgeois individual subject a thing of the past, it is also a myth; it never really existed in the first place... Rather, this construct [...] sought to persuade people that they "had" individual subjects and possessed some unique personal identity” (1958-59). Dicho de otro modo, la posmodernidad (o posmodernidades) que sintetiza Jameson se entiende como un desafío al individualismo moderno, en la medida en que pretende desvirtuar el mito de que podemos diferenciarnos de los demás en base a una serie de cualidades distintivas, sean materiales, morales, religiosas, o pertenecientes a cualquier otra categoría divisiva.

En este Bildungsroman de Mastretta, el discurso posmoderno gira en torno a su ambición revisionista del género. En el contexto patriarcal de México durante la primera mitad del siglo XX, la novela de formación de Mastretta hace resistencia a los patrones 
tradicionales de formación femenina. Como resultado la novela acepta la imposibilidad de representar un proceso formativo equivalente al de los textos tradicionales del género. Al mismo tiempo se niega a presentar una serie de etapas formativas que conduzcan gradual y sucesivamente a una madurez sellada con el matrimonio y la plena satisfacción de la protagonista dentro del entorno doméstico. Algunos estudios como el de Nadia Dolores Avedaño argumentan que la novela "follows the classic pattern of the Bildungsroman” (45). Sin embargo, según el enfoque crítico de este trabajo y sin negar la incorporación de algunos elementos característicos del modelo convencional, el texto ofrece una multitud de pistas que apuntan a una representación no tradicional y contestataria del proceso formativo. Los fundamentos de la ideología posmoderna en Arráncame la vida se pueden investigar enfocando aspectos fundamentales que la distinguen de los modelos tradicionales del género tanto en sus variantes masculinas como femeninas. Entre los asuntos que plantea el texto de Mastretta se destacan lo que podríamos llamar la crisis de representación del proceso formativo femenino, la tendencia a subvertir los principios de orden y madurez que caracterizaban al Bildungsroman tradicional y la preferencia por un lenguaje accesible (anti-elitista) que recicla la producción de la cultura popular, lo cual fomenta la tolerancia y la aceptación, al menos en el terreno literario, de identidades ambiguas y conflictivas.

La crisis de representación del proceso formativo en el texto que nos concierne queda planteada desde las primeras intervenciones narrativas, donde se evidencia que el proceso formativo no será convencional. Inmediatamente después de haber conocido a Andrés, Catalina reflexiona acerca de su propia limitada educación formal. Explica que en su juventud las mujeres no recibían una educación secundaria. Y aunque ella tuvo la 
oportunidad de asistir a un colegio religioso clandestino asegura que le fue de poco provecho, reconociendo que "casi ninguna mujer iba a la escuela después de la primaria”, y que terminó sus estudios básicos “con una mediana caligrafía, algunos conocimientos de gramática, poquísimos de aritmética, ninguno de historia y varios manteles de punto de cruz” (11). En efecto, durante el tercer mandato de Porfirio Díaz se prohibió que las mujeres ejercieran la docencia excepto en los grados de la educación primaria ${ }^{22}$, lo cual negaba a la población femenina acceso a una educación secundaria (Anna Macías 11). Es decir, la formación de la Catalina adolescente no se nutre de las curiosidades ilustradas y humanistas que advertimos en otros protagonistas en las variantes convencionales del género. La protagonista de Mastretta articula un proceso de formación alternativo, que en gran medida redime y legitima el valor de la educación oral y su importancia en la formación femenina hispanoamericana.

En principio, se puede argüir que la elección de dicho proceso formativo alternativo solidifica las bases del pensamiento posmoderno del texto. Al hablar de crisis de representación en Arráncame la vida nos referimos a la serie de interrogantes que surgen a raíz de la presentación de una protagonista cuya “formación” se caracteriza por su hibridez, ambigüedad y autoconciencia de una identidad múltiple y fluida ${ }^{23}$. Esto

${ }^{22}$ Según Macías, "the unwillingness of the leaders of the Porfirian society to permit women to teach beyond the primary grades became evident after 1889, when the Secondary School for Women in Mexico City became the "Normal de Profesoras". Until 1889 the graduates of the secondary school were certified to teach primary and secondary schools, but after that date the course of study at the normal school was reduced from six to four years, and its women graduates were certified to teach in primary schools only" (11).

${ }^{23}$ Según Jane Elizabeth Lavery, "Catalina is also a hybrid combination in the sense that she is both passive and active, independent and dependent..." (51). 
sugiere, en palabras de Linda Hutcheon, que "it is not that representation now dominates or effaces the referent, but rather that it now self-consciously acknowledges its existence as representation - that is, as interpreting (indeed as creating) its referent, not as offering direct and immediate access to it” (60). Partiendo del principio de que para los escritores modernos el acto de representación implica un proceso de mediación y, por consiguiente, un punto de vista privilegiado, podemos argumentar que el texto de Mastretta presenta una actitud contestataria con respecto al discurso pedagógico que favorecía el Bildungsroman tradicional. En vez de asumir la comprometida responsabilidad de prescribir un modelo lineal de desarrollo moral y sentimental, la novela de formación posmoderna se niega a definir los principios de madurez individual a partir de los valores hegemónicos que se construyen en la modernidad.

La capacidad de Catalina de presentarse como carente de educación secundaria cumple una doble función. Por un lado le permite operar como una narradora ingenua, desconocedora de los pormenores de la historia mexicana dada su carencia de formación libresca y, por otra parte, le permite acentuar la formación oral y cultural que sí ha recibido. La estrategia narrativa le va a permitir disentir, cuestionar, y en ocasiones ignorar eventos políticos e históricos contemporáneos sin comprometer la verosimilitud de su narrativa. La aparente carencia de autoconciencia narrativa le otorga libertad para seleccionar los episodios que le interesan, dejando a un lado otros asuntos menos pertinentes para su historia personal. Además, tal estrategia facilita la manipulación del lector, quien no tiene acceso a la totalidad de la conciencia de Catalina dada la narración en primera persona. 
El asunto del aprendizaje en las novelas de formación tradicionales se ha estudiado a fondo. Numerosos críticos coinciden en que las heroínas del Bildungsroman tienden a desarrollar una curiosidad intelectual y pasión por la lectura a una edad temprana. Según el estudio de Esther Kleinbord Labovitz acerca de la novela de formación femenina europea, "no single theme illuminates the female Bildungsroman more than the heroine's mode of self-education through reading” (32). Esto se debe, en parte, a las transformaciones en el ámbito literario y la revolución en la industria de la imprenta que tiene lugar en la Europa del siglo dieciocho. Como también explica Todd Kontje, "as these cultural developments might lead one to suspect, most of the protagonists of these texts are avid readers” (5). En cambio, Mastretta abandona el modelo tradicional del Bildungsroman y presenta un personaje protagónico carente de la preparación intelectual ilustrada que predomina en las variantes femeninas del género. De hecho, como se ha planteado anteriormente, lo que se representa en Arráncame la vida al respecto es una explicación histórica y sociocultural en cuanto a la falta de escolaridad de Catalina.

El limitado acceso a la educación formal que obtuvo la narradora permite suponer que a ello se debe el feminismo a medias que manifiesta a lo largo de la historia. Si pensamos en el feminismo como una serie de teorías o construcciones ideológicas se hace evidente que Catalina, dado su entorno histórico-cultural, difícilmente hubiera podido recibir la suficiente instrucción formal como para manifestar una postura feminista consciente y coherente. Sabemos que, en ocasiones, ésta aparenta personificar una sólida ideología feminista. No obstante, en otros momentos nos quedamos con la impresión contraria. Por ejemplo, refiriéndose al sufragio femenino en México, afirma con 
indignación que "en casi todos los estados las mujeres no tenían ni el pendejo derecho al voto que Carmen Serdán había ganado en Puebla” (107), haciendo notar que, a pesar de no haber recibido una educación superior, está al tanto de ciertos asuntos políticos de importancia que afectan la participación de las mujeres en la sociedad.

En cambio, abundan circunstancias en las que Catalina muestra una tendencia a la resignación y al escapismo que nadie consideraría feministas. Ésta revela un sistema de valores morales en continuo proceso de revisión, especialmente notables cuando se encuentra ante situaciones abrumadoras. Cuando empiezan a llegar a oídos de Catalina rumores de que su marido era un criminal, ésta sostiene:

Yo preferí no saber qué hacía Andrés, era la mamá de sus hijos, la dueña de su casa, su señora, su criada, su costumbre, su burla. Quién sabe quién era yo, pero lo que fuera lo tenía que seguir siendo por más que a veces me quisiera ir a un país donde él no existiera, donde mi nombre no se pegara al suyo, donde la gente me odiara o me buscara sin mezclarme con su afecto o su desprecio por él. (57)

Asimismo, en reiteradas ocasiones Catalina manifiesta una profunda insatisfacción con su propia identidad que pareciera tornarse en auto desprecio. Con expresiones como "quería llorar y meterme en un agujero, no quería ser yo”, “otra quería yo ser”, “quería estar distinta para ver si me volvía otra” y "había inventado cambiarme el aspecto”, se evidencia un estado psíquico sintomático de la ambigüedad e incertidumbre con los que aprende a batallar en los primeros años de matrimonio (59). Se muestra, una vez más, dispuesta a asumir un proceso formativo no esencialista u orientado según postulados morales convencionales. Su entrada al mundo adulto es una etapa repleta de 
contradicciones y desilusiones. Sin embargo, es importante aclarar que Catalina no demuestra interés en tomar acción de ningún modo que pueda comprometer su acomodado estatus social ni provocar un escándalo dentro de los cánones sociales de la época.

Es posible atribuir su manifiesta ansiedad al hecho de que reconoce abiertamente que le falta voluntad para abandonar las comodidades que disfruta por el hecho de ser la esposa de Andrés Ascencio, por conflictivo que le parezca dado desempeño social. No se trata de una sensación de impotencia en abstracto. Se sabe que cuando intenta escapar, siquiera momentáneamente tomando un autobús hacia Oaxaca, reflexiona que “antes de llegar al primer pueblo ya [se] había arrepentido” porque el autobús “se llenó de campesinos cargados de canastas, gallinas, niños que lloraban al mismo tiempo” (57). Carolyn Malloy argumenta que Catalina tiene poca consciencia de la lucha de las mujeres en general (32). Ciertamente no abundan los ejemplos de una Catalina socialmente consciente de cuestiones relacionadas al estatus de las mujeres en la sociedad, en escasas ocasiones demuestra cierto conocimiento de la lucha de algunos sectores femeninos. No obstante, pocas veces exhibe un interés genuino por los asuntos que afectan a las mujeres más vulnerables de su sociedad.

Como bien ha notado Aída Apter-Cragnolino, “el malestar que a veces la sobrecoge se ve compensado por su fascinación con la riqueza o el poder virtual que Andrés le procura” (130-31). Sobran ejemplos de ello durante la campaña de Andrés por la gubernatura de Puebla. Ante la interrogante del general, Catalina confirma que sí le gustaría ser gobernadora admitiendo que dejó de hacer el "intento de crearle un pasado honroso” a su marido y que, “en dos semanas [pasó] de ser una tranquila madre sin más 
quehacer que cuidar dos bebés, a ser la jefa de cuarenta sirvientes” (44-46). En este episodio vemos como Catalina paulatinamente se justifica y asimila el carácter doble de Andrés, de manera que comienza a funcionar del modo que lo hace éste, priorizando, por encima de todo, su conveniencia.

Con el ascenso de Andrés a la gubernatura de Puebla, Catalina adquiere una nueva faceta pública. Además de las nuevas labores que debe desempeñar como primera dama del estado, Andrés la hace presidenta de la Beneficencia Pública. A su cargo ahora quedan el manicomio de San Roque ${ }^{24}$, la Casa Hogar y algunos hospitales públicos. Pero a Catalina realmente no le agrada la idea y solicita deshacerse de sus nuevas responsabilidades públicas. Ya se “sentía perseguida por un ejército necesitando” de ella. Andrés, por su parte, hace caso omiso de las excusas de su mujer diciéndole -“No creas que todo es coger y cantar” (51). Ante la negativa, ésta se dispone a hacer uso de su recién adquirida autoridad proponiéndose conseguir fondos públicos para intentar mejorar las condiciones de las enfermas y los niños huérfanos. Así nos enteramos de que algunas de las internadas del manicomio son ex amantes de Andrés a las que le conviene mantener confinadas en la institución mental:

\footnotetext{
${ }^{24}$ Según la tesis de Andreé Bojalil Daou, el hospital San Roque se fundó en Puebla a finales del siglo XVI y comienza a atender enfermos mentales exclusivamente a principios del siglo XVII debido a la existencia de otro hospital general en la ciudad. En 1861, bajo la presidencia de Benito Juárez, los hospitales religiosos se secularizan y su administración y mantención financiera pasa enteramente a manos del gobierno. Afirma Bojalil Daou que "Las mujeres que no se apegaban al comportamiento socialmente esperado eran trasladadas al hospital siendo dadas de alta en muy pocas ocasiones lo que probablemente provocaba miedo” (13).
} 
¿Quién podría pagar mis obras de misericordia? Mi marido, claro. En la tarde me dijo que estaba yo exagerando, que ni un centavo extra para el hospicio o los hospitales y que las locas ya tenían bastante con su edificio. -Pero si ya fui a ver y no tienen camas -dije.

-Nunca han dormido más arriba del suelo esas mujeres -me contestó -. ¿Tú crees que hay locas ricas ahí? Las ricas andan en la calle. -Y contigo -le contesté. (51)

Vale notar que Andrés aparentemente ha premeditado el cargo que le otorga a Catalina, sugiriendo que ella misma es una de esas mujeres ricas que andan en la calle y que, en cualquier momento, se les puede encerrar por “locas”. Es cierto que al gobernador le conviene utilizar a Catalina para hacer campaña de relaciones públicas. No obstante, aquí Andrés más bien pareciera pretender proporcionarle un castigo anticipado a su esposa, como si previera las “locuras” a las que se atreverá Catalina más adelante en la novela. De hecho, la descripción de las mujeres ingresadas en San Roque corresponde a la imagen que se ha ido formando Andrés de su esposa. Catalina recuerda ingenuamente que eran "mujeres clavadas en la niñez... pasando de la euforia a la depresión” y afirma que durante la inauguración del manicomio - “con todas bailó el gobernador, también conmigo, que no me sentía mal entre ellas” (50). Es decir, Andrés se da cuenta, relativamente temprano en la narración, que Catalina no va acogerse a las normas de conducta tradicionales femeninas. Éste sugiere que ella es una de esas mujeres que, si no fuera porque es su esposa, probablemente también estaría internada en San Roque. 
La subversión de las normas de formación personal es clave para apreciar las propuestas teóricas del texto. Dado que la novela no presume de una finalidad pedagógica, vale subrayar que Mastretta se abstiene de insertar juicios de valor en cuanto al comportamiento de Catalina. Evita favorecer normativas de conducta particulares, optando, en vez, por una narrativa desinhibida y tolerante de posibilidades formativas no convencionales. Entre las experiencias formativas que quedan subvertidas en el texto se destacan la representación de la vida conyugal tradicional así como la conflictiva experiencia de la narradora con la maternidad.

Como se ha dicho anteriormente, la temprana edad y las circunstancias históricas y regionales de la protagonista al contraer matrimonio son de suma importancia para entender la dinámica entre Catalina y Andrés. Desde sus primeros encuentros con su futuro marido, Catalina demuestra una actitud desinhibida y desafiante. Sin embargo, no se trata de una postura del todo feminista. Más bien, es producto de una combinación de dos factores interrelacionados. Por un lado, se destaca el hecho de que su modelo de adultez predominante en la infancia fue masculino - el de su padre - y, por otro, se evidencia la falta de modelos femeninos tradicionales dada la disminuida presencia afectiva de la figura materna. Asimismo, es notable que parte de sus impresiones iniciales del general Ascencio son también producto de su juventud y falta de experiencia tanto intelectual como sentimental.

Lo cierto es que, aunque sus impresiones y sentimientos con respecto a Andrés cambian dramáticamente con el pasar del tiempo, su actitud irreverente hacia el general es una constante desde el inicio hasta el final de la narración. Al comienzo, Catalina recuerda cómo se sentaba a oír las conversaciones entre su padre y Andrés cuando éste 
último la cortejaba - "me sentaba a oírlos y a dar opiniones con toda la contundencia que me facilitaban la cercanía de mi padre y mi absoluta ignorancia” (7). No obstante, a pesar de reconocer sus limitaciones intelectuales en las disquisiciones de los "adultos”, mantiene los rasgos más característicos de su personalidad -desafiante, ambigua e indescifrable.

En su lecho de muerte, Andrés le confirma - "No me equivoqué contigo, eres lista como tú sola, pareces hombre, por eso te perdono que andes de libertina. Contigo si me chingué. Eres mi mejor vieja, y mi mejor viejo, cabrona” (223). Andrés se muestra consciente de los sufrimientos que le causó a Catalina; pero también reconoce que ella supo jugar su juego. “Te jodí la vida ¿iverdad?”, le pregunta Andrés en uno de los pocos momentos en que se muestra sentimentalmente vulnerable, "Porque las demás van a tener lo que querían. ¿Tú que quieres? Nunca he podido saber qué quieres tú. Tampoco dediqué mucho tiempo a pensar en eso, pero no me creas tan pendejo, sé que te caben muchas mujeres en el cuerpo y que yo solo conocí a unas cuantas” (225). Con esto reafirma que Catalina siempre fue un individuo contradictorio, híbrido y poco convencional cuya dualidad narrativa "incorporates both the complicity of being the same person who participated in the textual unfolding and whose duplicity allowed her to survive” (Gold 38). Sabe que, a pesar de todo, no logró someter el espíritu posmoderno de su esposa.

Algo que Catalina tampoco abandona en su desenvolvimiento sentimental es el extrañamiento y la distancia emocional con que mira a Andrés y las cosas que éste hace. Observa que aprendió “a mirarlo como si fuera un extraño, estudi[ó] su manera de hablar, las cosas que hacía, el modo en que iba resolviéndolas” (212). Podemos notar que, a 
diferencia de otras relaciones matrimoniales tradicionales, Catalina sufre un proceso de desapego emocional hacia Andrés. Al comienzo de la novela reza, "cuídamelo, virgencita; devuélvemelo, virgencita”, cuando las autoridades se llevan a Andrés preso, mientras que hacia el final de la vida de éste sospechamos que Catalina ha contribuido directamente a la muerte de Andrés y la vemos bastante convencida de que "la viudez es el estado ideal de la mujer” (232). A pesar de su inicial apego adolecente hacia Andrés, en realidad Catalina guarda cierta distancia afectiva a lo largo de toda la narración que sin duda se intensifica a medida que se adentra en la experiencia conyugal y, posteriormente, maternal.

La experiencia con la maternidad se presenta como la ruptura principal de Catalina con las convenciones de conducta femenina. Es un suceso que genera en ella una sensación de extrañeza y malestar. Recordemos que desde su primer embarazo a Catalina la maternidad le resulta un martirio:

Tenía yo diecisiete años cuando nació Verania. La había cargado nueve meses como una pesadilla. Le había visto crecer a mi cuerpo una joroba por delante y no lograba ser una madre enternecida. La primera desgracia fue dejar los caballos y los vestidos entallados [...] cuando empezó a moverse como un pescado nadando en el fondo de mi vientre creí que se saldría de repente y tras ella toda la sangre hasta matarme. (31)

Hay que remitirse al modelo de maternidad de la protagonista para comprender que desde niña, rechaza el ejemplo de maternidad que modela su propia madre. Esto se debe en parte a que, para ella, su madre siempre fue una fuente de represión sexual femenina. Percibe negativamente la actitud patriarcal de su madre, quien la "mira con cara de que 
ya es muy noche para [andar] fuera de [su] casa” y añade - “Ella nunca estaba fuera de su casa después de las cinco de la tarde, menos sin su marido. Yo le resultaba un escándalo” (110). Durante la infancia, la madre ya había inculcado en su hija vergüenza hacia su propio cuerpo y los procesos biológicos femeninos. Recuerda Catalina: "No me daba vergüenza la sangre, no como a mi mamá, que nunca hablaba de eso y que me enseñó a lavar los trapos rojos cuando nadie pudiera verme” (27). No nos debe parecer extraño, entonces, que Catalina más adulta rechace el supuesto instinto maternal de la mujer. Ya de antemano presenta una predisposición para rechazar los patrones de maternidad que le inculca su propia madre.

Para Catalina el supuesto suceso cumbre de la maduración femenina, que tradicionalmente se asocia con la plenitud adulta de la mujer, no es más que un inevitable fastidio biológico. Simone de Beauvoir propone en El segundo sexo que las manifestaciones biológicas de lo femenino no deben confundirse con los conceptos culturales de lo que significa ser mujer. Según la filósofa francesa, la maternidad restringe a la mujer a repetir el ciclo de la vida, lo cual la condena a la dependencia (568). A la heroína de Mastretta, en lo referente a la maternidad, tanto la realidad física del cuerpo femenino como las construcciones culturales de género y amor maternal le resultan ajenas. Además, presiente que con las responsabilidades que impone la maternidad se verá sometida al entorno doméstico y, necesariamente, distanciada de Andrés y del espacio de las libertades masculinas. De hecho, uno de sus conflictos y motivos de depresión durante y después del embarazo es que Andrés le presta menos atención sexual, relegándola al indeseado espacio femenino tradicional. 
El primer encuentro sexual extramarital de Catalina sucede precisamente durante su primer embarazo. Recuerda que su amigo del colegio sentía más apego por su hija Verania que ella misma - "Me trataba como a una reina. Nadie le tuvo más cariño que él al pobre bebé. Ni yo... Pablo se encargó de quitarme las ansias esos tres últimos meses de embarazo, y yo me encargué de quitarle la virginidad... eso fue lo único bueno que tuvo mi embarazo de Verania” (32). Catalina subvierte y desacraliza el período del embarazo, comportándose como se comportaría Andrés, a quien, claro está, no se le imponen las restricciones sexuales y morales que recaen sobre la mujer encinta.

A pesar de la intención subversiva que comunica la experiencia maternal de Catalina, vale notar que en otros momentos, conforme a su conveniencia, ésta mantiene una actitud pasiva y tradicional, más acorde con las expectativas sociales de la sociedad patriarcal y del Bildungsroman femenino europeo. De acuerdo con Marianne Hirsch, uno de los rasgos característicos de la novela de formación femenina es precisamente el carácter pasivo del personaje protagónico. Éste no se encuentra en condición de controlar su propio destino y se limita a reaccionar a lo que le sucede (297). La aún adolescente y recién casada Catalina recoge una serie de características fundamentales de lo que podemos llamar una personalidad posmoderna. Demuestra, por ejemplo, una sorprendente capacidad para lidiar con las incertidumbres de su nueva vida conyugal. Refiriéndose a Andrés, comenta con serenidad: “Ahorita yo lo quiero... quién sabe después”, demostrando que no le interesa convencerse de las normativas de amor y fidelidad conyugal prescritas a la mujer en las sociedades tradicionales (21).

La fe que en principio manifiesta la Catalina adolescente hacia la integridad moral de Andrés se deshace poco después del nacimiento de su primera hija, Verania. Catalina 
asegura que “no sabía nada de la vida de Andrés” luego de que éste “entró en la casa con los dos hijos de su primer matrimonio" anunciando que se iban a quedar a vivir con ellos (33). Catalina reconoce que no tiene control sobre su propia existencia y se da cuenta que todos los acontecimientos que le suceden giran en torno a decisiones tomadas solo por Andrés. Por tanto, vemos como Catalina paulatinamente pierde la confianza. Asegura “De ahí para adelante no le creí un solo discurso” y “Decía tantas mentiras”, alegando que si en principio le tenía alguna confianza, la actitud tanto pública como personal de Andrés ha ido deshaciéndola (46). Además, se da cuenta que Andrés siempre le ha sido infiel, lo cual probablemente contribuye a que a ella tampoco le interese serlo.

Algunos estudios han caracterizado la relación adúltera entre Catalina y Carlos Vives $^{25}$, explicado que se trata del verdadero amor de Catalina. Según Marcelo Fuentes, Vives “constituye el único hombre a quien llega a querer tanto como a Andrés” (51). Sin embargo, más allá de la innegable atracción que comparten, Vives se convierte en un escape para Catalina. Es símbolo de todo lo que le falta en su matrimonio y es, sentimental e intelectualmente, lo opuesto de Andrés. Esa es la razón por la que Andrés lo manda a asesinar, porque encarna una serie de principios de masculinidad y, sobre todo, de justicia, que el tirano no puede tolerar. Recordemos que Andrés le advierte: Dedícate a tu música y tus intelectualidades, dedícate si quieres a las mujeres complicadas, pero no te metas en política, porque este es un trabajo que hay que saber hacer. A mí no se me ocurre dirigir orquestas, y

\footnotetext{
${ }^{25}$ Posiblemente es un elemento autobiográfico; Carlos era el nombre del padre de Mastretta.
} 
te aseguro que es mucho más fácil pararse a mover las manos frente a una bola de mariachis que gobernar alebrestados y cabrones. (169-70)

Además de su padre, Carlos es la segunda persona sentimentalmente más cercana a Catalina. Andrés, previsiblemente, los desprecia a ambos por igual.

En más de una ocasión se hace evidente que Andrés no ignora la infidelidad de Catalina. Durante una cena a la que asistía Carlos Vives, Andrés le hace saber que sabe de la infidelidad de su mujer, explicando cómo han cambiado las mujeres modernas y como ha cambiado Cati: "La hubieran conocido ustedes a los dieciséis años, entonces si era una cosa linda, una esponja que lo escuchaba todo con atención, era incapaz de juzgar mal a su marido y de no estar en su cama a las tres de la mañana” (170). Esta caracterización que hace Andrés sugiere una asociación simbólica entre su mujer y el mito de La Malinche. Andrés da a entender que Catalina, como La Malinche, es una mujer de dos caras y que, por tanto, no es de fiar. Según Lavery, “Andrés believes that women are treacherous by nature" y que "Catalina is deceitful and embodies in some respects the treacherous Malinche figure” (69).

Al mismo tiempo que se presenta el Bildung de la protagonista, se evidencia como su formación queda supeditada a la formación de Andrés Ascencio. Como ha señalado Danny J. Anderson, la novela comienza con la llegada de Andrés, “a manipulating opportunist who struggled to power in the aftermath of the 1910 revolution, and concludes with his funeral” (16). En otras palabras, el texto inicia y concluye con los acontecimientos fundamentales en la vida del general Ascencio, aunque narrados a partir de la perspectiva femenina de su esposa. Por tanto, el proceso de formación de Catalina se ve profundamente ligado a los momentos cruciales de la vida de su esposo, ya que ésta 
se dedica a contar su historia - la de Andrés - tanto como la suya propia. En gran medida, como se ha sugerido anteriormente, la formación de la heroína de Mastretta es función del recorrido personal de Andrés Ascencio en su búsqueda del poder político. Catalina, en gran medida, asume e incorpora la perspectiva masculina de su marido en la narración de su propia historia. Hace suyo, además, el lenguaje masculino para fusionar su historia con la del general.

La crudeza del lenguaje de Catalina es posiblemente el elemento formal que puede desconcertar a quien espere encontrarse con una novela de formación tradicional. En cuanto al lenguaje de Catalina, la propia Mastretta ha dicho que “Catalina is very vulgar - she uses slang and bad words” (García 76). Lo que es interesante notar aquí es que dicho lenguaje parece ser el lenguaje interno de Catalina, la voz de su conciencia. No obstante, es una voz que, en ocasiones, pareciera confundirse con el vocabulario masculino y desinhibido que utiliza Andrés. El lenguaje de su retrospección es un lenguaje tan híbrido como su identidad, en parte propio, en parte aprendido en los años de convivencia con Andrés. Asimismo, es fundamental para la verosimilitud de la narración que Catalina sea capaz de remedar el lenguaje del sujeto al que describe y quien, en última instancia, influye tremendamente en el desarrollo de su propia voz narrativa y el desenvolvimiento de su identidad personal.

Si bien la voz “vulgar” de Catalina le imparte episodios de cierta comicidad al texto, es importante apuntar la apropiación subversiva que hace del lenguaje patriarcal, masculino de Andrés para resistir el encasillamiento en modos expresivos estereotípicamente femeninos. La protagonista desmitifica la imagen estereotípica de la mujer correcta y delicada, al tiempo que reclama, dentro de ciertos límites, su derecho a 
una expresión autónoma y liberada. Hay que reconocer que Catalina, como ha dicho Lemaître, goza del enorme beneficio de ser esposa y viuda de un hombre rico. Esto le otorga libertades de expresión que no tendría si fuese una mujer soltera, divorciada o pobre $^{26}(114)$. De modo que no podemos suponer que su intención y capacidad subversiva responda a una preocupación y rebeldía feministas. Su privilegiado estatus social le permite decir cosas que posiblemente no diría si no fuese una mujer adinerada. Conjuntamente con el tono ingenuo y el lenguaje vulgar dominante en el texto es notable el también frecuente tono humorístico que utiliza Catalina para narrar su historia. Tal combinación de ingenuidad y humor vulgar produce un efecto que en ocasiones puede sugerir ironía mientras que, en otros momentos, acentúa la voz infantil.

Con la enfermedad de Andrés, Catalina una vez más rompe, ahora de manera siniestra, con el patrón tradicional de esposa abnegada. El lenguaje que implica a Catalina en la muerte de su marido se torna convenientemente ambiguo, hecho que obscurece la posible interpretación de que sea la autora intelectual de la muerte de Andrés. No obstante, la visita de la viuda del "asesinado en el ingenio de Atencingo”, Carmela, para traerle las "hojas de limón negro” para su “dolor de cabeza y para otros dolores” sugiere que, al menos parcialmente, se involucra en la muerte del marido. Catalina comunica las indicaciones y advertencias del remedio - "el té de esas hojas daba fuerza pero hacía costumbre, y había que tenerle cuidado porque tomando todos los días curaba de momento pero a la larga mataba... Me las llevaba porque oyó... que me dolía la cabeza y por si se me ofrecían para otra cosa” (201). Los efectos de una sobredosis del té pueden

\footnotetext{
${ }^{26}$ Según Lemaître, Catalina se beneficia "del respeto que se le otorga a la esposa legítima y al sufrimiento que el sistema patriarcal le infunde, por definición, a la viudez” (114).
} 
producir un paro cardiaco. Irónicamente, la enfermedad de Andrés hace que éste también presente unos fuertes dolores de cabeza, de modo que Catalina le ofrece la bebida que ella misma consume. Sin embargo, ésta nunca le comunica que le puede provocar la muerte y confiesa que ella no la bebe en las cantidades que se la da a beber a Andrés (217).

El estudio de Lemaître explica el terreno simbólico de la muerte de Andrés. Propone que el "té de Carmela” no solamente es el instrumento de liberación de Catalina, sino que funciona a modo de vehículo narrativo para vengar la muerte del marido de Carmela y, por extensión la de "todos aquellos asesinados o mandados a asesinar por Andrés” (113). Asimismo, la utilización de las yerbas peligrosas sugiere la asociación del mundo femenino con los poderes de la tierra, la naturaleza y la brujería ${ }^{27}$. Las mujeres ejercen dominio en el mundo de remedios medicinales que se pueden emplear para combatir malestares de salud, y como parece ser el caso de nuestra narradora, también pueden utilizarse con motivaciones homicidas. Catalina, recurre al dominio ancestral femenino en el terreno del conocimiento herbario con el fin de socavar, a través del rito hipnótico, el poder patriarcal de Andrés.

Además del conocimiento popular de remedios naturales, Mastretta reclama un espacio narrativo para la cultura popular, mesclando en la novela la presencia de la alta cultura, elitista, con la cultura popular, de acceso masivo. Hay una serie de factores que producen el interés del texto posmoderno en América Latina por la mezcla y la hibridez

\footnotetext{
${ }^{27}$ En Aura de Carlos Fuentes existe un precedente importante en las letras mexicanas de la representación de la mujer hechicera. Así como Consuelo emplea su conocimiento herbario en sus ritos sincréticos, aquí Catalina similarmente utiliza el saber femenino de plantas medicinales para socavar el poder hegemónico masculino.
} 
cultural. Uno de ellos es el proceso de modernización económica, urbanística y tecnológica de los países latinoamericanos y su definitoria hibridez étnica, lingüística y religiosa. García Canclini sugiere que "los países latinoamericanos son actualmente resultado de la sedimentación, yuxtaposición y entrecruzamiento de tradiciones indígenas" que ha producido "un mestizaje interclasista [y] ha generado formaciones híbridas en todos los estratos sociales” (71). El texto posmoderno de Mastretta no se justifica en la perpetuación de las distinciones estéticas según las autoridades estéticas. De cierto modo reivindica la validez cultural de variadas expresiones artísticas ya sean consideradas cultas o populares. Así desarticula los discursos jerarquizados de las manifestaciones culturales.

Desde la elección del bolero que da título y significado a la novela, se evidencia la intención autoral de desdibujar las artificiales líneas divisorias entre la alta cultura y la cultura popular y, en última instancia, entre el arte considerado legítimo y las variantes populares que suelen considerarse malas copias o degeneraciones del "verdadero" arte. Jameson alega que es precisamente "the erosion of the older distinction between high culture and so-called mass or popular culture” lo que más angustia ha producido desde el punto de vista académico, desde el que tradicionalmente se han resguardado celosamente la superioridad de las manifestaciones de la alta cultura (14). Asimismo, explica Marcelo E. Fuentes, que la presencia de la música de artistas populares en el texto, tales como Toña la Negra o Agustín Lara, demuestran la “cercanía inevitable” entre los artistas y los más altos círculos del poder político (53). No se trata, pues, solamente de otorgar legitimidad a la producción cultural popular, sino también de señalar cómo toda 
manifestación artística, ya sea considerada culta o no, se ve involucrada en la maquinaria del poder político.

Como se ha sugerido hasta aquí la interpretación predominante en cuanto al desenvolvimiento intelectual y sentimental de Catalina ha sido que ésta, en efecto, pasa por un progresivo y relativamente exitoso proceso de crecimiento personal. Es una perspectiva bastante extendida entre los críticos, que la protagonista de Mastretta "matures, has children, learns the lengths her husband will go to in order to consolidate his power... examines the world she moves in with a critical eye” (Edwards 101). Sin embargo, como se ha propuesto en el presente capítulo, Catalina en realidad carece de un proceso formativo coherente y progresivo como el que sugiere la explicación de Edwards. Su integración social y desenvolvimiento individual se ve restringido por toda una serie de convenciones patriarcales y carencias personales. Lo que consigue exponer a lo largo de su experiencia formativa es la arbitrariedad y provisionalidad de las más sagradas convenciones de la experiencia femenina -el ideal de la fidelidad conyugal y el de la predisposición maternal. Asimismo, Mastretta se ocupa de desarticular el modelo formal del Bildungsroman, incorporando elementos de la cultura popular y desenvolvimientos históricos que típicamente no se incluyen en las narrativas de formación convencionales.

Con el entierro de Andrés se cristaliza un ambiguo y simbólico desenlace narrativo, indicio de la respuesta posmoderna de Mastretta a los desgastados metarrelatos de la modernidad. En su última reflexión -“Cuántas cosas ya no tendría que hacer. Estaba sola, nadie me mandaba. Cuántas cosas haría, pensé bajo la lluvia a carcajadas. Sentada en el suelo, jugando con la tierra húmeda que rodeaba la tumba de Andrés. Divertida con 
mi futuro, casi feliz.”- Catalina ofrece un desenlace repleto de posibilidades interpretativas, ninguna definitiva (238). Por un lado, sugiere que ya no tiene nada más que decir; con la muerte del esposo su voz narrativa se apaga de manera definitiva. Por otra parte, es posible concluir que cesa de narrar al haber alcanzado cierta plenitud y libertad individual, de manera que continuar la narración se hace innecesario. Asimismo, su conclusión sugiere que, al verse sola por primera vez en la adultez, iniciará una nueva y más íntima etapa formativa, donde puede dejar de narrar y de narrarse a sí misma. Por último, el final también puede entenderse como un regreso simbólico a la infancia; en sus propias palabras -al juego y a la diversión, como antes de haberse involucrado con Andrés. El típico desenlace, coherente y de fácil acceso, en esta novela de formación no se da. Estas posibles lecturas sugieren un replanteamiento del proceso formativo y de los fundamentos narrativos tradicionales del Bildungsroman. 


\section{CAPÍTULO 2: ANTES (1989)}

\subsection{REPRESENTACIÓN DE ORFANDAD, INTERIORIDAD Y TRAUMA INFANTIL}

En 1978 Carmen Boullosa debuta en el terreno literario como poeta. Antes es su segunda novela, publicada en 1989, y se reconoce como uno de sus tres Bildugnsromane entre los que también se incluyen Mejor desaparece (1987) y Treinta años (1999). Antes relata la historia de una niña no nombrada que nos presenta su infancia, aparentemente, después de haber muerto. El título se refiere a la etapa antes de la adolescencia y de la subsiguiente muerte. La niña vive acosada por una serie de perseguidores que le hacen la vida desgraciada y de los cuales sabemos muy poco, salvo la impresión de que son una personificación de las fobias de la infancia. Podemos decir que el miedo infantil es una de las características distintivas que mueve los hilos de la trama y que finalmente provocan la muerte de la niña cuando llega a la adolescencia y experimenta la primera menstruación. La negación del período de formación nos llevará a explorar las implicaciones teóricas que se desprenden de dicha propuesta narrativa. Con Antes, Boullosa parece proponer una poética de la posmodernidad anclada en el terror infantil y la imposibilidad representativa del proceso formativo.

La novela de crecimiento, como se expuso en el capítulo introductorio, se adapta en la postmodernidad a las inquietudes propias de fin de siglo y el contexto histórico hispanoamericano, manteniendo algunos de sus rasgos y temas constituyentes, pero ofreciendo testimonio de una nueva crisis espiritual. Las jornadas formativas en las novelas de Carmen Boullosa se ven amenazadas por barreras afectivas y discursivas que trastornan o tronchan el desarrollo de las protagonistas, convirtiendo a la infancia en una 
experiencia aterradora. Según se verá en Antes, la negación del sujeto estará implícita en el punto de vista de la voz narrativa. La propia existencia física de la joven protagonista y de los hechos que se narran se problematizan, producto del recuerdo y la memoria. El anhelado acceso a la madurez y la plenitud espiritual perseguida por el protagonista del Bildungsroman convencional es irrealizable e inaccesible para su homólogo en la posmodernidad. El umbral hacia la pubertad queda cerrado, anulándose así, el protagonismo histórico del personaje, que subsiste como voz narrativa y reminiscencia de ultratumba. El texto se revela así como un ejemplo de anti-bildung femenino postmoderno.

En The Powers of Horror Julia Kristeva ha postulado que: "on close inspection, all literature is probably a version of the apocalypse that seems to be rooted, no matter what its socio-historical conditions might be, on the fragile border (borderline cases) where identities (subject/object, etc.) do not exist or only barely do—-double, fuzzy, heterogeneous, animal, metamorphosed, altered, abject” (207). Boullosa hace uso de esa explicación, optando por un relato de formación, en efecto, apocalíptico, al menos dentro del mundo interior que es la conciencia de la niña. La frágil frontera de la que habla Kristeva adquiere en Antes una variedad de posibilidades interpretativas. Pueden entenderse, por una parte, como la frontera entre la conciencia y el sueño o, por otra, como la vida y la muerte así como la inocencia y la perversión. En Antes se representa la reacción visceral (la abyección) al sinsentido aterrador que supone la posmodernidad, en concreto, su negación de “realidades” fijas y fácilmente distinguibles.

Boullosa construye un universo narrativo que entreteje voces y corrientes múltiples que posibilita, a través del enfoque infantil, a una mayor comprensión de la 
condición posmoderna sobre la cual han disertado críticos como Lyotard y Zygmunt Bauman. La investigadora Anna Reid en su estudio "Haunting inheritances: persecutions and the uncanny in Carmen Boullosa’s novel Antes" propone que "two interlinking thematic concerns run through Boullosa's novel: the effects of Catholicism on the social imagination and the loss of innocence through puberty, both of which embody notions of religious fear and guilt emanating from the Original Sin” (41). Se enfoca en esta novela a una época de la historia de México correspondiente a las décadas de los años cincuenta y sesenta. Se trata de un contexto sociocultural que expone a una clase social deslumbrada consigo misma y con las promesas del progreso, pero que, no obstante, se ve acechada por la herencia cultural híbrida de la que es producto. Es a través del planteamiento de dicha hibridez cultural que la obra de Boullosa se inserta en el panorama crítico de la posmodernidad. La modernidad mexicana se problematiza poniendo al descubierto el entramado de creencias y supersticiones que pervive en el imaginario mexicano al margen de su nueva fe en el progreso y a pesar de los cambios materiales que se van sucediendo en su historia. Reid ofrece pistas importantes a la hora de entender la crítica posmoderna en la obra de Boullosa al excavar la historia de la religión de la Nueva España y enlazar el imaginario popular con el presente mexicano según se presenta en la obra. Las creencias precolombinas, la ubicuidad de la imaginería católica y el arraigo de una nueva colonización tanto cultural como económica se verán reflejadas en la vida de la protagonista y su entorno social.

El Bildungsroman boullosiano incorpora elementos temáticos y estilísticos que son propios del género de la novela gótica. El ambiente del castillo habitado por lo desconcertante y amenazador se trasplanta a la ciudad de México para transgredir, esta 
vez, el santuario doméstico de la burguesía mexicana. En otro de sus artículos, “Transformando la infancia: elementos góticos en la narrativa de Carmen Boullosa”, Reid afirma que el recurso de invertir "la seguridad y tranquilidad del espacio de la casa familiar” constituye un rasgo dominante del discurso anticatólico que predominó en el mundo anglosajón como resultado de la Reforma (96). Con el pretexto de la influencia estilística de dicho género anglosajón Boullosa resucita el lado oscuro de la tradición católica, con lo cual se nos remite a la leyenda negra del proceso colonizador español. Asegura que:

aunque el lenguaje que prevalece en Antes se asocia con los símbolos (clavos, estigma, ángeles, llaga, ampollas, llamado) y apoyos (cirios, ayunos, cilicios) del catolicismo, abruma la presencia de un lenguaje más siniestro (persecución, caza, llamas, arder, condenar). Estas palabras están relacionadas más con el infierno y el purgatorio, con la herejía y la brujería, asimismo la persecución y lo sobrenatural corresponden al gótico y su anti-catolicismo. (98)

Reid sugiere que ambos elementos en la novela, el que se desprende del imaginario espiritualista de la Contrarreforma católica y los elementos góticos de los cuales se ha servido Boullosa en la obra, contribuyen por igual a la sensación de horror que experimenta la protagonista en la brevedad de su existencia. A ello es necesario sumar la sensación de horror que producen en la misma los efectos de la modernidad mecanicista y ególatra: la soledad, la apatía, la discordia y la alienación. De tal manera se puede observar cómo a través de la pluralidad de discursos que se autosocaban en la obra la 
autora de Antes se construye un texto autocrítico y autorreflexivo, acorde con los postulados de la posmodernidad.

La inocencia infantil, eje fundamental de la novela de formación decimonónica, se convierte en Antes en vehículo de crítica postmoderna. La novela de formación femenina según la plantea Boullosa, apunta, en consecuencia, a lo descarnado y a lo aterrador de la infancia femenina dentro del contexto de la posmodernidad mexicana. El relato autobiográfico que nos trasmite la narradora comienza a mediados de la década de los años cincuenta y todo parece indicar que concluye hacia el cierre de la década de los sesenta con el desenlace fatal de la protagonista antes de alcanzar la pubertad. La vida de la niña transcurre en el seno de una familia pequeño-burguesa mexicana y se verá condicionada por la educación tradicionalista que recibe junto a sus hermanas en un colegio de monjas. No obstante, la atmosfera de indiferencia afectiva y espiritual que se respira en el entorno familiar más la intromisión de fenómenos sobrenaturales que invaden la vida cotidiana conforman un texto fundamentalmente distinto al de los relatos de formación tradicionales. La psiquis y lenguaje infantil de la protagonista dan testimonio de una crisis representativa del Bildung que queda tronchado. Tanto la psiquis como el sistema simbólico del lenguaje se ven invadidos por el miedo que todo lo distorciona y paraliza.

Maria Beville propone en Gothic-postmodernism: Voicing the Terrors of Postmodernity que el gótico según se manifiesta en la posmodernidad es todo un género literario. Considera que en el posmodernismo gótico “all concepts of reality are tinged by the darkness and horror of transgression” (60). Explica que el género desempeña un rol fundamental para explorar la subjetividad posmoderna, puesto que la representación del 
terror y lo inimaginable le permite al lector redefinir el concepto del “yo” (56). La investigadora establece paralelos entre lo que significó la literatura gótica para la modernidad europea durante con la revolución francesa (y el Reino del Terror) y la “condición posmoderna”. El elemento gótico se empleaba entonces como un vehículo expresivo para exorcisar los miedos y ansiedades de la sociedad decimonónica a medida que avanzaba hacia orden capitalista. En la actualidad el imaginario gótico recobra vigencia, similarmente, para manifestar los terrores ontológicos de la contemporaneidad posmoderna (23). De la misma forma, el Bildungsroman como género se desarrolló en la Europa decimonónica para representar las tensiones entre el individuo moderno y su contexto dentro de un nuevo orden social. Hoy en día, la novela de formación se retoma como género idóneo para expresar distintas tensiones dentro de un nuevo espacio filosófico y cultural.

Las visiones fantasmagóricas presagian el destino de la protagonista y al mismo tiempo ponen en entredicho, no solo la vida de la niña, quien parece narrar su historia desde el más allá, sino además las certezas hegemónicas (crueles y repugnantes en Antes) que suponen los grandes discursos de la modernidad. El marco de la vida cotidiana queda asediado y socavado por los elementos sobrenaturales que conforman el texto. El recurso de la fantasmagoría (el mundo “desverbal” al que alude la niña, de aterradores fantasmas en las noches, en el que se desdibuja lo corpóreo para dar paso a lo incorpóreo, y viceversa) da voz y forma artística a la fragmentación de la vida moderna. “Con el tiempo aprendí a verlos,” cuenta la niña, asimilando la presencia in crescendo de el miedo que se incrementa a medida que ésta se va alejando de la inocencia infantil para entrar en la adolescencia (40). Se problematiza, además, el cuerpo femenino como antítesis de la 
pureza judeocristiana, ya que la niña es rechazada y atemorizada desde el instante de su nacimiento. Según propone Carol Clark D’Lugo, en Antes Boullosa despliega una crítica explícita en contra de la Iglesia, exponiendo los “tentáculos” y el arraigo de la institución en la sociedad mexicana. (74). Así, el espacio formativo de la niña se ve, desde el inicio, afectado por un mundo aterrador que se fundamenta, en parte, en la tradición católica y su debilitado poder hegemónico. El espacio narrativo, por consiguiente, se presenta como una (de)formación del proceso de desarrollo de la protagonista, irrepresentable e inmaterializable.

La conciencia infantil, vulnerable e indefensa, se presenta como una apertura, permeable y porosa, por la que transitan las perturbadoras voces y ruidos hostiles que problematizan la realidad tal como la percibimos. Las extrañas apariciones que invaden la cotidianidad de la protagonista parecen acosar además a otras dos niñas en la obra, según el reporte de la protagonista y, finalmente, son compartidas con la propia madre hacia el final del texto, una vez que ganan terreno dentro del hogar los fantasmas que la persiguen y le arrebatan la vida. Boullosa entreteje lo real y lo fantástico en la psiquis del personaje, enfocando su atención en los procesos psicológicos de la niña a medida que intenta dar significado a sus emociones y percepciones. Se pone de manifiesto un trasfondo de soledad, alienación, indiferencia y desprecio, que no solo parece penetrar el terreno de lo privado y de lo doméstico, sino que también dictan, previsiblemente, las conductas de la vida pública fuera del hogar. La muerte de la protagonista antes de cruzar el umbral de la adolescencia, imposibilita su recorrido formativo, el cual es la razón de ser y objetivo fundamental del género en su variante convencional. Todo discurso, sea religioso, económico, científico o de otra índole, que se imponga a la interioridad del individuo, 
parece intimar Boullosa, socaba su integridad (y su humanidad) y deriva en espectros. Surge la interrogante, asimismo, de cómo sobrevive el Bildungsroman como género hacia el último cuarto del siglo XX, una vez que se impone un protagonista que fallece en el intento de encarar su propio período formativo dadas sus realidades históricas dentro del contexto del México posmoderno.

Narrador y protagonista se funden mediante el discurso indirecto libre autorreflexivo sobre los acontecimientos más destacados de la infancia, dando paso a una situación de ambigüedad e indeterminación de la voz narrativa ${ }^{28}$. El paisaje de desamparo y los vacíos afectivos que comienzan con el nacimiento de la protagonista enmarcan el comienzo de la obra, observándose cierto orden cronológico en la trama. Los recuerdos inverosímiles e impresiones de su propio nacimiento dan inicio al recuento testimonial de las privaciones afectivas de que es objeto la niña. La hostilidad del entorno se hace patente desde el inicio con el momento de la madre dar a luz y la penosa desilusión de la abuela al conocer el sexo de la niña. "Mi abuela me miró con desilusión porque yo no era varón como ella hubiera querido” (14). Desconcierta, sin duda, la narración en primera persona y la "memoria" de la recién nacida que percibe el desamor y desamparo de la abuela, quien al privarla del afecto que requiere un bebé para su desarrollo físico y emocional, la deja vulnerable a los asedios del mundo exterior, representados simbólicamente aquí por los acosadores fantasmas.

${ }^{28}$ Según explica Santiago Juan-Navarro, en el texto autorreflexivo "la distinción entre los discursos se difumina, como se difumina también la frontera entre arte y teoría, entre ficción y realidad” (34). 
Uno de los asuntos fundamentales de la novela es la representación de la orfandad espiritual y emocional que sufre la protagonista, en parte, a causa de su género. Es una orfandad representativa de la vulnerabilidd y el vacío espititual que genera "la condición pomoderna”. "La narradora vive aislada, en distintos grados, tanto de sus parientes adultos (su madre, su padre y su abuela) como de sus hermanas y compañeras de escuela. Los personajes hacen acto de presencia a ratos contra el trasfondo de la narración [...], cuyo tema predominante es, sin lugar a dudas, el miedo...” (Gallardo 178). La recepción vacilante del nacimiento por parte de los progenitores se torna en decepción mutua, en indignación y espanto. Refiriéndose a la madre en el momento del parto, la protagonista nos dice que su:

miedo era por la abuela, no por mí. A mí, ¿qué? Todavía ni me veía [...], la jovencita, bañada en sudor, despeinada, con el cuerpo sometido a la violencia del parto, despojada de todos los signos de su coquetería, era inocultablemente hermosa. Ese día estaba más pálida que de costumbre y cuando la vi por primera vez tenía en todos sus rasgos reflejado el miedo que no imaginé brincaría a mí para nunca dejarme. (12-13)

La expectativa del lazo afectivo de primer orden —el de sus progenitores y parientes más cercanos — se ve fundamentalmente traicionada. La primera emoción de la madre es de miedo, reflejo de la preocupación consigo misma, y no de regocijo y apego hacia la recién nacida.

La penetrante y distante mirada de la madre “me recorrió el cuerpo,” nos dice, “poniéndome en todas las partes que lo componían su nombre respectivo, volteándome huesos y piel con un sentimiento similar a la ternura, como no me volvió a ver nunca 
nadie” (14). La maternidad genética se desarticula para insinuarse que, lejos del concepto natural de la maternidad idealizada y arquetípica, ésta debe ser construida sobre las bases de la intencionalidad, la incondicionalidad y el afecto. El amor que siente la niña por las figuras femeninas en su vida no es correspondido, por lo que los procesos psicobiológicos de apego emocional entre madre e hija se imposibitan:

ponían en mí sus manos exageradamente blandas y me cantaban canciones desentonadas. Las quería mucho, tanto que no sólo me arrullaba con ellas sino que en las mañanas, al despertar, mi primer pensamiento era para ellas dos, y al salir de la escuela también era para ellas dos. Casi toda mi infancia. (14-15)

Por otra parte, la ausencia del padre a su llegada al mundo es recibida con reproche y es igualmente representativa del impedimento afectivo:

...no lo recuerdo a él esa noche. ¿Dónde andaría? Diré que trabajaba para no ofenderlo, pero en cuanto vi la palidez de ella y la extraña miseria que la rodeaba entre sábanas y las manos impías (quiero decir sin cariño ni piedad) que la rodeaban, lo supe todo. [...] él no me miró ni ese día ni los siguientes, hasta que perdí la cuenta. Entonces, cuando dejé de notar que no me miraba, lo hizo y jugó conmigo. (13-14)

Julianna Gallardo señala que la figura de los fantasmas o perseguidores en Antes cumple la función, al menos en parte, de "llamar la atención” al hecho de la soledad y el aislamiento que sufre la niña como resultado del individualismo enajenador que se manifiesta dentro del núcleo de la familia (176). La investigadora explica que "solamente las hermanas mayores, Male y Jose, parecen disfrutar de la mutua compañía de la otra, 
pero en esta familia nadie está realmente pendiente de nadie” (177). La niña nace, pues, a una traumante experiencia vital definida por la alienación y la orfandad. Su aterradora experiencia terrestre queda demarcada por la oscuridad del útero (del cual es expulsada como un deshecho) a la oscuridad permanete de la muerte.

En este caso, una casa embrujada u ocupada por los fantasmas que conducen a la protagonista a la soledad, la enajenación y el miedo, actúa como alegoría del egoísmo y del individualismo cercenador que impera afuera, en el núcleo de la sociedad, y que termina arruinándola. Como indica Gallardo:

la narradora nunca reúne el valor necesario para hablar con alguien más, sea un miembro de la familia, una maestra o una compañera de la escuela, sobre los ruidos que le quitan el sueño; trágicamente, el único momento en que la niña se siente comprendida por otra persona es cuando su madre alcanza a ver a los perseguidores al morir. (176-77)

La niña, no obstante, intenta inutilmete sobreponerse a las barreras afectivas: ...busca dormir con su abuela, que no siempre la deja; [...] toca a la puerta de sus hermanas, pidiendo entrar [...] La niña es rechazada en todas estas tentativas de acercarse a sus seres queridos; en el momento de su primera menstruación, cuando está a punto de dejar atrás la niñez que ha contribuido a su aislamiento para aproximarse al mundo adulto en que vive el resto de su familia, los perseguidores la matan. (177)

La crisis de la modernidad penetra asimismo en la raíz del lenguaje, desestabilizando la relación entre significado y significante. El miedo definitorio de la protagonista proviene de la vulnerabilidad que supone carecer de lenguaje para nombrar 
la experiencia humana. “Tengo tanto miedo”, nos dice, “y no hallo cómo gritar mamá. Es un grito que no puedo emitir, porque esa palabra no la tengo” (15). De acuerdo con la teoría de Ferdinand de Saussure el signo lingüístico es arbitrario puesto que no existe una relación interna entre el signo lingüístico y el concepto al que éste se refiere ${ }^{29}$. Dadas las circunstancias de alienación aterradoras que padece la protagonista de Antes la relación arbitraria entre el concepto de "mamá" y el signo que se utiliza, por convención, en la comunidad lingüística española (la palabra “mamá”) no se establece. La niña queda pues, deshabilitada, lingüísticamente hablando, de la experiencia con el concepto de “madre” y las asociaciones que se derivan del concepto significado por el significante. Esto supone un terror existencial, atávico ${ }^{30}$, que solo puede tratarse narrativamente a través del lenguaje poético e infantil con el que Boullosa caracteriza a la protagonista. El lenguaje de la voz narrativa apela a las imágenes, a las emociones viscerales, y al ritmo poético que puede evocar el terror que la prosa (convencional) no puede representar. El lenguaje adulto, parece sugerir Boullosa, es incapaz de comunicar el pavor “desverbal” que experimenta la niña.

De manera semejante a lo que ocurre en Treinta años, la figura de la madre es para la niña un ser inaccesible. Comenta la niña, "aunque la vi desde siempre con tanta precisión, la quise mucho, como si fuera mi madre. ¿Cuánto tiempo tardé en darme cuenta de que ella no era mi mamá? Siempre lo supe, pero hasta el día en el que ellos

\footnotetext{
${ }^{29}$ Véase The Critical Tradition [p.843]

${ }^{30}$ Así se refiere Boullosa al miedo que representa en Antes. Veáse entrevista de Erna Pfeiffer [p.36].
} 
llegaron por mí, todo funcionó como si ella lo fuera” (13). A diferencia del modelo clásico del Bildungsroman, los cuidadores en el modelo posmoderno de Boullosa no propician el distanciamiento del joven adolescente, que en todo caso mantiene relaciones afectivas profundas con sus progenitores, sino que, por el contrario, imposibilitan radicalmente la atadura emocional. Esta es una distinción fundamental, ya que al no existir un vínculo entre el personaje protagónico y el progenitor, se borra el pretexto que tiene el joven, del modelo clásico, para emprender su jornada formativa. La existencia del vínculo afectivo, por problemático que pueda ser, posibilita el paso del héroe tradicional hacia la aventura iniciática. En cambio, según la propuesta de Boullosa, en Antes la justificación del inicio formativo no existe, lo cual contribuye a la imposibilidad de que se dé una jornada de formación.

La escena de la sopa de tortuga ilustra el trauma infantil que resulta del contraste entre la inocencia y la insensibilidad de los mayores. Anteriormente, la mascota se había mostrado como uno de varios elementos en la vida de la niña que sirve de resguardo y refugio ante el entorno inhóspito e indiferente de la casa: “Caminé en la oscuridad con la tortuga entregada a mi pecho como una amante indefensa, aterrorizada como yo, y le hablé en voz baja, le dije: “voy a cuidarte, pierde cuidado”, le acaricié la concha y la cabeza apoyada en mi hombro,... y dejamos de oír el ruido que estábamos persiguiendo” (44). Es durante el hecho afectivo, mediante la comunión espiritual que establece la niña con ciertas actividades y objetos -vehículos que le permiten escapar provisionalmente a la amenaza que la cerca—, que logra dispersar los fantasmas que la asechan:

...se rieron todos los de la mesa, menos yo. Estallé en llanto. Sin control metí el pelo en el plato de sopa, en el despreciado plato de carne con 
plátanos verde que hasta antes de ese día me había hecho tanta ilusión. Mientras Esther me decía “de qué lloras, cálmate, a ver”, mi abuela creyó ser más astuta y dijo “cree que nos estamos comiendo su tortuga, la que desapareció”. (47)

La aspereza de la escena y la crueldad que percibe la niña se desasocia del ideal pedagógico del Bildungsroman tradicional. La asimilación del dato cruel e imprevisto por parte de la protagonista supone un asalto a su inocencia, y se devela como patrón histórico de la experiencia formativa femenina, caracterizada por vivencias alienantes y traumáticas.

La crítica al sujeto heredero del proyecto de la modernidad cobra fuerza en el papel del padre, figura de escaso protagonismo en la obra y hacia quien la narradora no parece profesar mayor reverencia. Todo lo contrario. Su función se ve regida por automatismos cotidianos, tanto el de conducir diariamente a las hijas a la escuela, como los de su propia profesión de químico. Su distancia espiritual y la incapacidad de asumir el papel de padre alude a un aspecto importante de la crisis de la posmodernidad: la insostenibilidad y desmoronamiento de los discursos clásicos, en este caso, el del patriarcado y la expectativa del núcleo familiar. Por tanto, el carácter absurdo y grotesco de su discurso con sus hijas es recibido con indignación y denuncia por parte de la protagonista.

...tomaba el camino a la escuela, como siempre, hablando de lo de siempre, de un juego que él creía inofensivo pero que para mí era un juego de asalto y de dolor. "Yo no soy su papá”...Yo no soy su papá... yo soy un señor que se las va a robar, un robachicos... un ladrón... me las voy a 
llevar para pedir dinero a cambio de ustedes...” Ahí les ganaba la risa, a él y a mis hermanas [...], mientras yo pensaba: ¿chicharrón? ¿Dinero? ¿De qué demonios -pensaba—, de qué demonios estaremos hechas? (16) El humor desagradable y torpe que proviene del padre, asimismo, pone de manifiesto la crisis de la posmodernidad: la invertebración de las identidades producto de la ilegitimidad de los discursos que intentan sostenerlas. Por tanto, dicha crisis genera y culmina en la estética de lo siniestro y perverso que se observa en la obra, en la atmosfera de deformación y tinieblas que experimenta la niña. Se trata, pues, de una familia (y una cultura) heredera de los relatos magisteriales de la modernidad, conformada por personajes indignos del respeto de la niña y con los que ella no consigue establecer vínculos emocionales significativos. La alienación que manifiesta todo lo imbuye; y sobrepasa la soledad "superficial” de una familia apática. Más bien es indicio de un pavor existencial que proviene del reconocimiento de la soledad ineludible de la experiencia individual del ser humano.

La ausencia de criterio propio en los miembros de la familia se observa además a través de la admiración desmedida que siente hacia personajes de superior clase social en la obra, tal como Don Pedro Vázquez Cisneros, cuyas dudosas intenciones y raro aspecto caricaturiza la narradora. Frecuentaba el hogar y "se sentaba a fumar pipa en un sillón que no tenía ninguna presencia en la casa, que no se notaba más que cuando don Pedro venía a presumir sobre él su boina gris que quién sabe por qué no se quitaba, a lo mejor porque era calvo o a lo mejor porque intuía cuán codiciosamente se la envidiábamos (80). Asimismo se regocijaban al decir: ““‘don Pedro Vázquez Cisneros es un intelectual”, sin que yo entendiera qué querían decir con ello” advierte la narradora (79). Por dicha 
personalidad “sentían Esther y papá un afecto fervoroso, pronunciaban su nombre con devoción profunda y el apelativo que le habían endilgado, y lo escuchaban hablar boquiabiertos, respetuosos, como oyendo un sermón de la iglesia” (80) De igual modo rendían culto los padres a cierto escritor cuya identidad escapa a la memoria de la narradora; “¿se llamaba Spota?”, se pregunta, “uno de esos seres míticos en los que [...] creía ver la férrea voluntad que él no tuvo para dedicarse a las humanidades, como creía haber querido, porque él se dejó convencer por la familia de que debía estudiar algo con futuro económico, algo que le garantizara parte del banquete, del atracón que la época iba a darse con la magia de la química” (81). Queda así expuesto el criterio de la narradora respecto a las flaquezas del padre, quien se deja llevar por los discursos positivistas de la familia y, por extensión, de la sociedad, incapacitándolo para tomar el timón de su voluntad y forjarse un destino propio. También se hace referencia explícitamente en este fragmento al enfrentamiento que se genera entre los discursos clásicos tradicionales y los discursos críticos posmodernos.

Como se ha ido apuntando hasta ahora, este Bildungsroman se caracteriza por el ambiente de asedio y persecución físicos y psíquicos que percibe la protagonista, principalmente en las noches y dentro del hogar, contribuyendo a su sensación de horror. A medida que la protagonista se va acercando al período de la pubertad, el asedio acústico y fónico del inicio se intensifica y va dando pie a manifestaciones más tangibles y aterradoras de lo diabólico. El elemento de lo incorpóreo e inanimado, lo maligno, se inserta en todas las capas de la realidad, adueñándose, en lo sucesivo, de los discursos del cuerpo, la familia, la cultura y la cosmovisión de una contemporaneidad que, en última instancia, conforman el discurso crítico que es la obra en sí. 
La invocación de lo sobrenatural y lo demoníaco proviene, como indica Anna Reid, de un discurso subversivo ya antes utilizado por la novela gótica (98). La respuesta del género gótico respecto a los discursos hegemónicos de rechazo de lo irracional y lo inexplicable se dispone a exponer las propias contradicciones ocultas de la Ilustración. “Las formas demoníacas que salen del género gótico revelan el desorden bajo la superficie del Siglo de las Luces y de la Razón” (98). Del mismo modo la obra de Boullosa se inserta en la contracorriente crítica posmoderna que expone la crisis espiritual en las sociedades informatizadas posindustriales como diserta Lyotard en $L a$ condición posmoderna. El lenguaje del terror que emplea el género gótico desarticula el discurso y los metarrelatos que avalan los conceptos de homogeneidad e integridad como medios del poder con el objetivo de desestabilizar el orden hegemónico. (Beville 199). Esto se puede apreciar, artísticamente, a través de la deformación física de personajes que pueden ser vehículo de discursos desgastados y desencaminados, que dan lugar a lo grotesco y deforme.

Lo grotesco en Antes se expone por medio de ausencias y vacíos espirituales y sociales que adquieren concreción en la presencia constante y en la función de los fantasmas. Con estas representaciones de almas vacías, espectros, monstruos y fantasmas, Boullosa propone legitimar y dar visibilidad al proceso formativo alternativo, que no necesariamente supera los miedos y obstáculos de la infancia sino que sucumbe ante ellos. La figura del alma, fundamento de muchos discursos humanistas y de la tradición judeocristiana, se pierde y se sumerge, para la protagonista, en el desorden de la modernidad mecanicista. Así, la retahíla de discursos totales es paulatinamente desdeñada y, finalmente, desechada por la perspectiva posmoderna, que se atreve a hacer frente a lo 
aterrador de la contemporaneidad. Desde el espacio discursivo de esa posmodernidad hay que lidiar con las ideologías desgastadas que aún rondan, persiguen y atormentan a sus "víctimas".

\subsection{EL BILDUNG TRONCHADO O LA POÉTICA BOULLOSIANA DE LA POSMODERNIDAD}

Mucho se ha disertado en la crítica de esta novela acerca del valor simbólico de los temores de la niña y los perseguidores que la acosan. Se ha analizado el asunto desde una perspectiva psicoanalítica y desde varios enfoques posmodernos. No obstante, la propuesta de Boullosa en este relato poético ${ }^{31}$ y misterioso ofrece además una oportunidad crítica acorde con la explicación que da Zygmunt Bauman en cuanto a las consecuencias (indeseadas) del proyecto de la modernidad. Hay en Antes un miedo que simbólicamente también tiene que ver con el pánico a la exclusión y al desarraigo, un temor que sobrepasa los límites narrativos y de la trama de la novela.

El incumplimiento del rol de los adultos en la familia, y por extensión de la sociedad, como salvaguardas de la infancia, la inocencia y de los más débiles constituye una traición que forma uno de los ejes esenciales en el discurso de la orfandad en la novela. Según propone Gallardo:

Antes, al ser narrada por una niña, presenta una tentativa por subvertir el orden adulto, caracterizado por el aislamiento y la indiferencia. La narradora lucha contra este orden al pedir los cuidados, la atención y el

\footnotetext{
${ }^{31}$ La propia Boullosa explicó su instinto poético al escribir esta novela: “en Antes tenía más una cosa de poeta, no es lenguaje nada poético, es un lenguaje incluso grosero y desagradable, pero tenía más la intención de poeta de que el lenguaje tuviera sentido” (Erna Pfeiffer 33).
} 
amor de su familia, lucha que se simboliza con la liberación de la tortuga, pero finalmente fracasa. Al igual que la tortuga, que termina asesinada y convertida en sopa, la narradora cae víctima de sus perseguidores al llegar al umbral de la adolescencia con su primera menstruación. (167)

Simbólicamente, la orfandad se construye en Antes como una consecuencia o residuo ${ }^{32}$ insospechado de la modernidad, producto del canje histórico entre los postulados de la modernidad y sus implicaciones prácticas. Las preocupaciones existenciales de la voz precoz de la narradora (debido a su percepción desde el espacio incorpóreo de la muerte) permiten sugerir que el entramado humanista es abandonado a favor de un nuevo espejismo, que es la fe ciega en el progreso material, con lo cual queda desatendida el alma, término que utiliza sin timidez la protagonista. La orfandad en la obra, por tanto, significa la marginación y el menosprecio, en la modernidad, de la interioridad, de la consciencia crítica y de la dimensión sentimental del ser humano.

Según propone Zygmunt Bauman, la modernidad ha derivado en una obsesión por el progreso material que obligatoriamente exige distinguir entre lo que tiene valor y lo que no. Llevado al terreno humano las implicaciones de su lúcida explicación son preocupantes porque se puede, desafortunadamente, hablar en estos términos materiales acerca de los seres humanos. Así se llega a la conclusión de que unos, y otros no, carecen de valor o son, como explica el crítico, "superfluos":

Ser "superfluo" significa ser supernumerario, innecesario, carente de uso sean cuales fueren las necesidades y los usos que establecen el patrón de

\footnotetext{
${ }^{32}$ Utilizo el término en alusión al texto de Zygmunt Bauman, Vidas desperdiciadas: La modernidad y sus parias.
} 
utilidad e indispensabilidad-. Los otros no te necesitan; pueden arreglárselas igual de bien, si no mejor sin ti. No existe razón palmaria para tu presencia ni obvia justificación para tu reivindicación del derecho de seguir ahí. Que te declaren superfluo, significa haber sido desechado por ser desechable,... "Superfluidad” comparte un espacio semántico con “personas o cosas rechazadas”, “derroche”, "basura”, “desperdicios”: con residuo. (24)

Los terrores que acechan a la niña a través de la novela representan un profundo temor a la deshumanización que supone la sensación, en especial para el niño, de ser excluido, de no ser valorado como persona, sino solo por atributos artificiales y arbitrarios. Ella es, de hecho, un ser "superfluo" en su casa y es consciente a un nivel instintivo y visceral que sus cuidadores podrían arreglárselas igual de bien sin ella.

El fenómeno que plantea la narradora de sentirse cercada, perseguida por los perseguidores que finalmente se apoderan de su existencia tiene precedente en la literatura hispanoamericana. "Casa tomada” de Julio Cortázar presenta un suceso fantástico, extraño, con ciertos paralelos con la sensación de acorralamiento que se da en Antes. En ambos textos se manifiesta lo que Boullosa ha llamado "un temor atávico” y donde lo que se "teme es el pánico de estar vivo, que es el momento en que tú tomas conciencia de..., se apaga la luz, y a pesar de eso tú no te vas, ahí estás y estás vivo, y estás consciente y el mundo se podría acabar, que igual estás tú ahí...” (Pfeiffer 36). En ambos relatos, el tener conciencia de sí mismo produce un estado de terror que paraliza a los protagonistas y que, ominosa y lúdicamente, se traslada a los lectores porque sugiere una serie de "relaciones" que trascienden el nivel de la trama. Como explica el propio 
Cortázar en "Algunos aspectos del cuento”, todos los buenos relatos, los que se recuerdan con el pasar de los años "son aglutinantes de una realidad infinitamente más vasta que la de su mera anécdota” (409). En Antes, de la presencia de los fantasmas que acosan a la niña surgen posibilidades, casi infinitas, de interpretación. ¿̇Acaso los “fantasmas” que atormentan a esta niña innombrada no son también representativos de los temores que rondan la conciencia de cada lector?

Se cuestiona el personaje “¿Por qué era blanco mi corazón?”, para sugerirnos a cada paso en la obra que es la pureza de su inocencia la causa de su pena física (la cacería y asedio de los ruidos), y, consiguientemente, de la evasión fantástica que puede deducirse como lectura alternativa a las experiencias alucinantes de la niña (39). Aquí el uso del vocablo blanco se utiliza con un doble significado - el del adjetivo que sugiere el color de la pureza infantil y el sustantivo que se refiere al objetivo de un disparo o de una acción. “iSe cuenta en tres frases o en dos cómo me perseguían cuando yo no era más que la indefensa que los esperaba sin poder alejarlos!, se dice con pocas palabras que toda la noche sin descanso me despertaban para acorralarme...” (39-40). Dicha pureza logra repeler y esquivar, aunque provisionalmente, el asecho de lo perverso, que gana terreno a medida que crece la protagonista. El desarrollo físico y mental de la niña se devela como el enemigo fatídico en la historia: “...no daban en el blanco, el blanco que era mi corazón antes de que lo devoraran del todo las tinieblas...” (39). En la obra, y por implicación, dentro del marco de la cultura el desarrollo ineludible hacia la adultez no da cabida a la inocencia de la niña. Con ello, la mera existencia del personaje se irá anulando, en parte debido a su propio rechazo a crecer. 
El estado físico de ser niño, por una parte, margina y niega el acceso de la protagonista al reino de los adultos, del que hacen alarde las hermanas mayores, enajenándola aún más. Por otro lado, aviva la determinación de la niña, quien rehúye de su propio crecimiento y reconoce que no es aceptada dentro del orden incoherente de su entorno doméstico y sociocultural. Con tal objetivo, la niña halla refugio en las herramientas retóricas absorbidas en el colegio de monjas. Por una parte el recurso del catolicismo ayuda al personaje a mediar los extraños acontecimientos de su vida, proveyéndole un lenguaje a través del cual enfocarlos y explicarlos, mientras que por otra parte la convierte en autora de su propio desenlace.

Al alcanzar la pubertad las hermanas se encierran en la recámara, “dueñas de una renovada complicidad que me había borrado, que me omitía como elemento” (116). La figura del “brasier”, objeto “más infranqueable que cerrojos, más fuerte que cadenas, más alto que el más alto muro [...] había llegado a separarme de mis hermanas.” Y añade, “sólo le faltaba cirios para subrayar la veneración súbita que sentían por él...”; poniendo de relieve el fetichismo de sus acciones por la prenda femenina (117). "No lo toques", “no es para niñas, es para señoritas”, la censura una de las hermanas. (117) Male, la mayor, es sorprendida, absorta en el acto exploratorio de probarse la "media de nailon”, acariciando su pierna "como estatua de santo, jugando a que ya hasta sus piernas eran de señorita” (117). La desilusión de la protagonista de cara al proceso de crecimiento en sí queda exaltado en el lamento de la perdida de sus hermanas a la impureza de la adultez: "Lloraba la falta de atención del par de hadas madrinas que habían velado el umbral de lo que yo era, impidiendo la entrada a monstruos del exterior, sin saber que lo que yo debía estar lamentando era la desaparición de las niñas que fueron mis hermanas” (118). El 
sentido de pérdida de las hermanas refleja el propio trauma de la protagonista vis à vis el tránsito hacia la adultez.

En su artículo "Voces femeninas en la novela mexicana actual: la infancia como estrategia en Carmen Boullosa y Bárbara Jacobs” Alicia Llarena comenta cómo la representación de la inocencia infantil se utiliza como herramienta crítica. La mirada infantil da paso a la perspectiva desde la periferia, a la mirada "no contaminada" de los discursos e ideologías hegemónicos de la modernidad, y desde la cual se advierten "las falacias del universo adulto” (376). "Lo adulto se percibe”, nos dice, “como una irreparable pérdida de humanidad... y esta pérdida gener[a] en los personajes una auténtica obsesión por no crecer, por resistirse a los estragos de la edad” (368). Aquí la infancia se figura como un despertar, una toma de conciencia al deshumanizado mundo adulto. La ruptura de la inocencia infantil con la pubertad asimismo se representa como una "iniciación mortal en la vida alienada de los adultos en la sociedad modernizada" (Barbara Dröscher 66). Boullosa, por tanto, opta por “sacrificar” a su protagonista con la primera menstruación antes que hacerla embarcar en el engañoso recorrido formativo hacia la madurez adulta.

El discurso católico de renuncia al cuerpo y a su sensualidad a favor de la búsqueda del perfeccionamiento espiritual arraiga en la imaginación de la niña. Las impresiones recogidas en el campamento, “equivalente femenino a los scouts” se tornan reveladoras y transformadoras para ella. Aquí no solo llega al reconocimiento del “abandono filial” definitivo (119), sino que se encuentra con otras niñas “viviendo la misma edad de tránsito que mis hermanas” (120). Mientras “las demás mortales”, refiriéndose a sí misma y a otras de su edad, "hacíamos gala de cómo quitarnos las 
prendas de vestir” sin pudor alguno, "porque nuestros cuerpos eran templos del Espíritu Santo", la protagonista observa cómo cierta niña mayor que ellas "se había ido a cambiar la ropa a la oscuridad del campo para que nadie le viera nada...” (120). Acto seguido, la protagonista describe a la joven de este modo: “... y luego entró con su ridícula y minúscula ropa de dormir casi transparente, descarada brincando y dando grititos [...] que fingían [...] denotar timidez, cuando en realidad eran continuas llamadas de atención que provocaban burlas de niña en niña por su anuncio de cuerpo de mujer” (120). El pensamiento de la protagonista alcanza una síntesis a través de la compasión, que se apodera de ella y trasciende el género femenino para abarcar al género humano: "Entonces pensé [...] que había querido ocultar su cuerpo de las miradas de las otras, porque [...] le avergüenza no tener ya el cuerpo de niña, y pensé en mis hermanas con compasión, y en Esther con compasión, y también pensé en papá, con compasión porque recordé que sólo los hombres van a la guerra...” (121).

La inocencia exalta la determinación de la niña, quien rechaza su propio crecimiento. Para ello la protagonista hallará refugio en las herramientas retóricas absorbidas en el colegio religioso. La imaginería del catolicismo ayudará al personaje a mediar los extraños acontecimientos de su vida, proporcionandole un modo a través del cual encararlos, mientras que por otra parte, le proporciona cierto control de su propio desenlace escabroso: esto es, la muerte de su inocencia, y con esta, la de su personaje: "Entonces fui yo la que me di la media vuelta y pensé: no me pasará nunca lo que ellas, yo no me voy a dejar, y pensando esto me quedé dormida, sin saber que mi fantástico deseo sería ingrediente para mi condenación.” (121). La protagonista prefiere no pasar a la adolescencia, etapa de transición entre la infancia y la adultez, donde obligatoriamente 
tendría que desprenderse de la inocencia infantil. Ésta se autoconvence de que es preferible la muerte que la pérdida del único período "puro" o incorrompido que tiene como ser humano. Lo que sigue a la infancia, para ella, es una incorporación al mundo adulto, de juegos macabros, de marginación y deshumanización.

Es indudable que la crianza católica moldea el carácter y la cosmovisión de la niña. El personaje muestra gran devoción hacia las lecturas religiosas que han informado su desenvolvimiento intelectual y los juegos de "santa y mártir”. Según afirma:

A mí me gustaban las vidas de santos que nos compraban en la casa en lugar de los comics [...] En cambio mis hermanas [...] no leían ni la portada de las Vidas ejemplares. Yo las devoraba. No que disfrutara leerlas, no, para nada, pero las seguía apasionadamente [...] Como no tenía éxito en la casa, después de leerlas se las prestaba a la abuela. Cuando la visitaba me las volvía a leer o me contaba sus historias. (62) Recuerda la narradora el dictado en clase de Mother Michael sobre el martirio de un particular santo que muere de miedo; terror similar al que sufre la protagonista. Se encomienda el reo a Abraham ante el prospecto de ser devorado por leones “como corderillo” en el circo romano. La bestia, no obstante, es intervenida por ángeles y se duerme a sus pies: "Pero había llegado la hora de recibir el galardón de sus trabajos. Comenzó a sentir una gran flaqueza y falta de fuerzas y ante los ojos atónitos de los infieles el Santo pasó a mejor vida" (28). Las historias de las vidas de santos, cuyo rol en la imaginería cristiana desempeña una labor pedagógica, sugieren un paralelo con la vida atormentada, casi de mártir que experimenta la protagonista. Su tormento es sintomático de terror existencial y la pérdida de integridad en cuanto a la identidad individual, 
nacional y cultural. El doloroso recorrido de la niña por la vida viene a simbolizar la pasión de Cristo -en sus juegos de “santa y mártir”, la alusión recurrente a la estigma de la crucifixión, la perspectiva narrativa desde un más allá de la vida terrenal, y su autorepresentación como una niña crucificada. A las alumnas del colegio de mojas norteamericanas se les pidió que dibujaran de tarea lo que para ellas significaba el lema de la escuela-"serviam, forever serviam, though life may lead us far away". La protagonista dibuja un “niño pequeño, acostado como un bebé pero de mayor edad” y cubrió todo su cuerpo de clavitos. La imagen del dibujo, curiosamente, no emitía ninguna “señal de dolor” y todo parece indicar que se trata de una representación de sí misma en su experiencia aterradora. Además, la imagen comunica una visión genuina de la idea de “servir” a Dios a través del martirio, mientras las otras niñas entregaban dibujos absurdos, según la propia protagonista, que no reflejaban verdadera devoción religiosa. De hecho, las falsas representaciones del serviam la llevan a preguntarse -“cuál “ayudar”...cuál serviam, cuál "servir” si entre nosotros nos encargábamos de que el país entero nos sirviera (92-94). En el ejercicio asignado se cifra el reconocimiento de una burguesía falsamente cristiana y falsamente al servicio de la fe.

Como en Treinta años, la narración de la formación es un proceso formativo en sí mismo. El espacio narrativo de la memoria le permite a la niña sin nombre adquirir señas de individualidad y explicar sus temores y su interioridad. Como aclara Stephanie Leigh Vague, "it is by navigating through the memories of these echoes that the narrator reconstructs the story of her childhood and tells of how she became who she is today... by telling her story and confronting the reverberations of her regrets she intends to overcome her solitude and find a portal out of her darkness” (87). La niña de Antes, 
asimismo, ante la imposibilidad práctica del bildung en la novela se construye al menos una explicación formativa a través del artificio del relato y desde el conocimiento de la muerte.

La fantasmagoría que invade al personaje adquiere cualidades reprensibles y obscenas; como explica la protagonista: “La obscenidad era para mí las formas que suplían a los cuerpos deformándolos, que los dejaba sin dedos para tocar, sin labios para besar, sin pechos para acariciarse, sin piernas ni tronco y que colocan, en donde debiera ir todo eso, nada más que formas que atemorizan...” (98). Da aquí más indicios la narradora del nexo entre la función de los fantasmas y el papel de los sentimientos, o de la problemática de la carencia afectiva en la obra. Una vez más habla desde el presente narrativo señalando: “A mí misma me he impuesto la obscena tarea de deformarme, de quitarme la facultad de abrazar, de arrancarme las formas que ocultan un cuerpo” (98). Se puede sugerir que en estos fragmentos la narradora alcanza una síntesis del conocimiento optando por el orden de la vida y los sentidos, y denunciando el idealismo esencialista platónico, por el cual el personaje se degenera en puro discurso etéreo, en un lenguaje incorpóreo, en un alma sin cuerpo ni nervios para sentir y abrazar.

La irrupción de lo sobrenatural y fantástico en la trama ocurre a través de diferentes modos de asalto a la realidad física; por ejemplo, a través del estigma en el cuerpo de la protagonista, que también aparece detrás de objetos como la pintura que termina desapareciendo, acontecimientos que se presentan como reclamos del más allá, o a través del contraste grotesco de objetos o sucesos fortuitos que devienen en un efecto de lo surreal que desestabiliza la referencialidad y la percepción. Según apunta Reid, la casa en Antes es un ejemplo de lo que Freud entendió por el vocablo alemán unheimlich, 
antónimo de heimlich, que denota situaciones que despiertan la sensación de inquietud, incomodidad e inseguridad, la de verse expuesto, casi siempre, por sorpresa, a lo no familiar dentro de lo familiar, y que produce, como resultado, un efecto estético de lo horripilante. "Una casa unheimlich es una casa habitada por fantasmas", en la cual "lo siniestro se da, frecuente y fácilmente, cuando se desvanecen los límites entre fantasía y realidad; cuando lo que habíamos tenido por fantástico aparece entre nosotros como real...”33 (Reid 100). El análisis de Freud, continua Reid, examina "la inversión de la familia y de los alrededores familiares de la casa... [evocando] una sensación de lo siniestro en Antes por objetos familiares como tijeras, la tortuga y piedras que asumen una vida propia para que ocurra un divorcio entre el objeto y la imagen que crea el objeto" (100).

Lo sobrenatural que persigue a la niña posee las características de un discurso maléfico, cuya estructura indescifrable supera el análisis y esfuerzo clasificador de la niña.

No pude inventarme de noche un código que agrupara los sonidos a los que le tenía pavor, pero los fui acumulando, armando un diccionario sin definiciones, un léxico auditivo. [...] No puse definiciones a los ruidos que enumeré porque las definiciones no me hubieran ayudado en nada, no me hubieran calmado o tranquilizado sino que hubieran enriquecido con más elementos la sazón del miedo. ¡Cuánto más me hubiera alarmado el saber de dónde y cómo procedían! (37-38)

${ }^{33}$ Cita del ensayo "Lo siniestro" de Freud en Reid. 
La protagonista-narradora termina encarnando lo desconocido que se presagia en su breve pasaje por el mundo. Culmina en nada más que "un poquito de carne a quien los recuerdos le impiden pudrirse, llenarse de gusanos y de moscas hasta acabarse” (103). La observancia mística junto con la asfixia social que sufre en vida dan lugar a su condición como narradora: narrador/a sin cuerpo ni alma, por el que transitan solo las voces distantes del recuerdo. Al final "acaba confinada en un espacio de destierro y soledad y sin lazos íntimos con los que curar su propia fragmentación, se queda sin cuerpo, para siempre a la deriva en un mar de oscuridad y muerte creado por una ausencia que todo lo imbuye” (Yolanda Melgar Pernías 38). Tal ausencia total, no obstante, puede verse además como un desafío emancipatorio. La niña, desde esta perspectiva, queda liberada del proyecto de maduración que le esperaría en vida. Queda también atormentada desde la ultratumba por las secuelas de su breve y traumante recorrido formativo.

El epígrafe del relato ofrece pistas importantes para las posibles interpretaciones de los fenómenos que se manifiestan en la novela. Se trata de un poema que Rubén Darío tituló "Nocturno" y que da inicio y, al mismo tiempo, adquiere mayor significado una vez concluido el relato:

Los que auscultasteis el corazón de la noche, los que por el insomnio tenaz habéis oído el cerrar de una puerta, el resonar de un coche lejano, un eco vago, un ligero rüido...

En los instantes del silencio misteriosos, cuando surgen de su prisión los olvidados, en la hora de los muertos, en la hora del reposo, sabréis leer estos versos de amargor impregnados...

Como en un vaso vierto en ellos mis dolores de lejanos recuerdos y desgracias funestas, y las tristes nostalgias de mi alma, ebria de flores, 
y el duelo de mi corazón, triste de fiestas.

Y el pesar de no ser lo que yo hubiera sido, y la pérdida del reino que estaba para mí, el pensar que un instante pude no haber nacido, ¡y el sueño que es mi vida desde que yo nací!

Todo esto viene en medio del silencio profundo en que la noche envuelve la terrena ilusión, y siento como un eco del corazón del mundo que penetra y conmueve mi propio corazón.

Los versos de Darío anuncian la disposición de Boullosa de expresar con emoción poética lo inexpresable en la prosa. Se cifran en el poema los miedos del devenir de la consciencia, que muchas veces irrumpen en los momentos de "silencio profundo" y de oscuridad nocturna. El poema también encamina al lector hacia el reconocimiento del poder del lenguaje lírico, oral, con el cual se crean los fantasmas y el artificio literario. El lenguaje crea mundos, ficticios y reales, a los que divide una frontera porosa, como lo es también la frontera entre el sueño y la vigilia, que se entrecruzan en la oscuridad y el silencio nocturno. El lenguaje también permite el rescate y la (re)creación de memorias turbias o incompletas; y fluye en la poesía del epígrafe como fluye por la conciencia de la protagonista, inseparable el uno de la otra. 


\section{CAPÍTULO 3: MAL DE AMORES (1995)}

\section{1. “TÚ NACISTE CON LUZ ELÉCTRICA”: LA IMPORTANCIA DE LA CRIANZA A LAS PUERTAS DEL NUEVO SIGLO}

Mal de amores (1996) retoma el modelo del Bildungsroman que habíamos visto en la primera novela de Mastretta para presentar la historia personal de Emilia Sauri a partir del trasfondo histórico de México desde finales del siglo XIX hasta 1963. A diferencia de Arráncame la vida, su segunda novela opta por una representación del proceso formativo femenino decididamente menos ingenuo, mediado por la selección estilística de la narración omnisciente y el desarrollo cronológico de la trama. Asimismo, la caracterización de Emilia marca un cambio significativo en las posibilidades narrativas de la figura femenina como heroína dentro de los parámetros del Bildungsroman. A pesar de pertenecer a una generación anterior al de la protagonista de Arráncame la vida, Emilia reclama un espacio intelectual y social femenino no explorado en la primera novela de la escritora. A diferencia de Catalina, la crianza de Emilia es una utopía concebida en el seno de la idílica familia Veytia-Sauri. La educación que recibe en casa la prepara para afrontar tanto el turbulento devenir de la nación mexicana en la última década del siglo XIX y las dos primeras del siglo XX, así como su propia historia intellectual y sentimental.

En el presente acápite y, respectivamente, en el siguiente, se estudiarán dos aspectos ilustrativos e interrelacionados de la novela que nos permitirán explorar sus bases y referentes posmodernos. Primeramente se analizará la voluntad revisionista de Mastretta en cuanto a la formación interior de la protagonista. Aquí se incluye la educación femenina tanto a nivel sentimental y moral como profesional. Además, se 
advertirá como la subversión de la ideología pedagógica patriarcal es un asunto determinante en la concepción de Emilia y de su modelo formativo. Posteriormente se estudiará el objetivo revisionista en cuanto a la narración de lo revolucionario, desde una perspectiva social y pública. Aquí se tratará de la representación femenina en el contexto histórico, político y social de la Revolución. Emilia Sauri expone una dinámica de lucha y participación femenina en una intersección histórica poco dada a la inclusión de la mujer en la vida pública. Ambos aspectos a estudiar en el texto conducirán a la reexaminación de la formación femenina como un fenómeno híbrido en el cual inextricablemente se entretejen tanto la esfera privada e íntima como la órbita pública y social.

Al contrastar las heroínas de ambas novelas de formación de Mastretta habría que subrayar sus respectivas diferencias en cuanto a autonomía y caracterización feminista. La resistencia a la opresión del entorno doméstico de Catalina, a pesar de sus incursiones en las actividades de orden público asignadas por Andrés, no sobrepasa el cerco del orden patriarcal. No es sino hasta la muerte del marido que ésta logra cierto grado de independencia, aunque debido a su calidad de viuda, jamás se deslinda completamente del perímetro intelectual prescrito a la mujer en la sociedad patriarcal. En cambio, Emilia se forja una identidad subversiva e independiente tanto en el ámbito público como en la esfera privada. Según explica Trinidad Barrera, la joven "no necesita adoptar o asumir ningún papel tradicional femenino, ni táctica, ni estrategia, porque de entrada se instala en otro orbe: que hasta el momento pertenecía únicamente al hombre” (35). De hecho, uno de elementos definitorios de Emilia Sauri es precisamente su verosímil resistencia a las categorizaciones elementales, particularmente si tenemos presente el contexto 
histórico en el cual crece. Su desenvolvimiento en el terreno profesional así como su toma de conciencia política atestiguan la participación femenina en asuntos de orden público que históricamente han correspondido casi por completo al dominio masculino.

Cabe preguntarse cómo es posible que funcione narrativamente un Bildungsroman que rompe con por lo menos dos aspectos claves del modelo clásico del género. En Mal de amores se pone en práctica un modelo que, primeramente, no se ciñe a los patrones educativos y sentimentales que informan la caracterización de los héroes de la novela de aprendizaje tradicional. Asimismo, la novela de formación posmoderna investigada aquí tampoco evita, como sí lo hacen los textos fundadores del género, la representación en un primer plano de disturbios políticos y actitudes revolucionarias como es el caso de la representación de la Revolución Mexicana en Mal de amores.

El carácter descentralizador que caracteriza la novela de formación posmoderna dialoga con el fenómeno también posmoderno o posnacional de la desarticulación de la idea de la nación. En Imagined Communities Benedict Anderson propone que el concepto de nación y, por extensión, de nacionalidad y de nacionalismo es una construcción social producto de la modernidad. Anderson ofrece una definición de nación que él denomina antropológica: "it is an imagined political community -and imagined as both inherently limited and sobereign... imagined because the members of even the smallest nations will never know most of their fellow-members, meet them or even hear of them, yet in the minds of each lives the image of their communion” (6). Tal fe en la comunión que comparten los miembros de una comunidad imaginada pierde validez en la posmodernidad. Si el Bildungsroman tradicional, europeo, alienta un proyecto esencialista de "la nación”, la variante posmoderna mexicana que se trata aquí descree de 
semejante unidad identitaria; la entiende más bien como un concepto o relato magisterial que no responde a la hibridez propia de la nación mexicana. En México en particular, el tema de la nación y la identidad del mexicano es un asunto que ha obsesionado a escritores de la talla de Octavio Paz y Carlos Fuentes. El segundo Bildungsroman de Mastretta retoma esa profunda preocupación desde un enfoque posmoderno, es decir plural, polifónico, desjerarquizado e inclusivo.

Representar en una novela de formación las viejas tensiones existenciales de México así como su proceso de modernización cumple una labor crucial y complementaria en el desenvolvimiento del protagonista. El proceso formativo posmoderno a nivel individual se ve mediado por la desarticulación del concepto de la nación a nivel del colectivo en la posmodernidad hispanoamericana. Comparten el individuo y el colectivo social así, un espíritu de lucha, una lucha por la visibilización de la pluralidad inherente en la identidad individual en el contexto nacional mexicano. Discursivamente tanto la idea de la formación personal progresiva y coherente como la de la nación llegaron a su cima luego de la Segunda Guerra Mundial. Desde entonces, tanto el primer metarrelato como el segundo han perdido vigencia, fragmentándose y metamorfoseándose en algo menos accesible, menos explicable, aunque también emancipador y menos opresor.

En las novelas de formación clásicas, como regla general, no hay cabida para la temática revolucionaria ${ }^{34}$ dado su objetivo conciliatorio y socialmente conservador. El Bildungsroman de Mastretta, en cambio, reclama su lugar en la literatura del género a

\footnotetext{
${ }^{34}$ Véase Franco Moretti p. 64
} 
partir del replanteamiento de lo revolucionario y lo subversivo tanto a nivel nacional en el ámbito público como en lo personal y en lo privado. La propia autora ha explicado que “during a revolutionary period, people dare to do incredible things...war allows you to do a lot of things that peace and society would probably change” (Mujica 36). A diferencia del modelo clásico, este tipo de Bildungsroman, lejos de suprimir la representación de lo revolucionario, lo resalta, apelando al potencial formativo del período turbulento, al tiempo que se autojustifica narrativamente en base a las libertades individuales que son ya posibles, o al menos verosímiles, dentro del contexto de la guerra.

Para abordar las bases formativas de Emilia, es útil entender primeramente el peculiar entorno familiar que anticipa el desarrollo de su carácter. El padre de Emilia, Diego Sauri, es un individuo a quien hoy en día podría catalogarse de feminista, sin temor a la equivocación. Es un individuo laico, liberal y apasionado por el conocimiento científico, particularmente por el legado médico indígena. Mastretta lo concibe como "uno de esos hombres extraños que respetan sin preguntas los designios de la autoridad divina encarnada en la mujer” (15). Asimismo, es un fiel defensor de la individualidad femenina y lo pone en práctica tanto en su vida conyugal con Josefa Veytia como en su desempeño como padre. De la caracterización de Diego Sauri se origina el desmantelamiento del orden patriarcal que tan determinante resulta en la formación sentimental, social y profesional de Emilia.

Llegado el momento de elegir un nombre para la primogénita de la pareja, es el padre quien toma la iniciativa de nombrarla Emilia, "para honrar a Rousseau y hacerla una mujer inteligente” (19). Se trata de un pasaje cargado de ironía intertextual dado a que el Emilo (1763) de Rousseau propone un modelo educativo para varones. Mastretta 
explícitamente subvierte los postulados pedagógicos del filósofo francés y al mismo tiempo reitera su propuesta posmoderna ${ }^{35}$ en tanto y en cuanto rechaza la noción progresiva del desarrollo y la perfectibilidad humanos. Para Rousseau, la crianza de los hombres y las mujeres no debía ser igual, puesto que cada sexo, por “designio natural”, posee diferentes talentos y habilidades intelectuales.

En el Emilio la crianza del varón estaba a cargo del tutor, el propio Rousseau, y no de los padres. La educación del niño se basa en cuatro ciclos formativos ${ }^{36}$ que progresivamente desarrollan y forman al individuo. Los ciclos o etapas que postula Rousseau se aplican como modelo educativo exclusivamente a los varones, de modo que, predeciblemente, se privilegia y prioriza el valor de la inteligencia masculina en la sociedad. En el Emilio, Rousseau mantiene que las mujeres tienen mayor habilidad para el juicio sentimental (siempre y cuando dicho juicio acate el limitado espectro de posibilidades femeninas), mientras que los hombres gozan de mayor capacidad para asuntos morales o de mayor rigor intelectual:

Consultad el gusto de las mujeres en las cosas físicas y que tienen relación con el juicio de los sentidos, y el de los hombres en las morales y que dependen más del entendimiento. Cuando las mujeres sean lo que deben ser, se limitarán a las cosas de su competencia, y siempre juzgarán bien,

\footnotetext{
${ }^{35}$ Según explica John B. Bury, la filosofía social de Rousseau es una crítica a la teoría del progreso que surge del racionalismo cartesiano a raíz de la publicación de El discurso del método (1637), texto que desplaza la teoría de la providencia.

${ }^{36}$ Las etapas formativas se determinan según la edad del alumno:

I: 1-5 años, etapa de desarrollo físico; II: 5-10 años, etapa de desarrollo sensorial a través del contacto con la naturaleza; III: 11-15 años, etapa de formación intelectual; IV: 15-20 años, etapa de educación moral.
} 
pero desde que se han convertido en árbitros de la literatura y a juzgar sobre toda suerte de libros y a escribir uno tras otro, ya no saben nada más. Los autores que consultan a las sabias sobre sus obras, pueden estar seguros de que siempre serán mal aconsejados. (237)

Rousseau asimismo arremete en contra de las mujeres que han pretendido extralimitarse de su inherente territorio intelectual y alecciona a Emilio respecto a los peligros de recibir de una mujer ningún tipo de información que corresponda al supuesto dominio masculino.

En su estudio de Mal de amores, Ela Molina propone que Mastretta efectivamente honra la obra de Rousseau al introducir un personaje femenino inspirado en el manual pedagógico de la Ilustración. Según Molina, Mastretta utiliza a “Emilio como modelo para la creación de su mujer perfecta... [reconociendo] la importancia e influencia del Emilio en la cultura contemporánea” (139-40). No obstante, cabe la pregunta, ¿hasta qué punto este homenaje no es también un modo de poner en evidencia las consecuencias de la filosofía educativa rousseauniana para la mujer latinoamericana? La conclusión de Molina de que Emilia viene a ser la "mujer ideal” de Mastretta no es del todo convincente, aunque ciertamente la propia Mastretta ha comentado que la figura de Emilia "is too perfect, because she is a dream" (Mujica 38). Si bien Emilia puede entenderse como una (muy reformada) representación del proceso formativo femenino, substrayendo toda presunción de alcance universal y permanencia epistemológica, también conviene reconocer que la experiencia de ésta es profundamente individual y que se sustenta, en parte, en las posibilidades discursivas del contexto revolucionario. Mastretta se abstiene de la propaganda pedagógica, optando por una heroína imperfecta, 
repleta de contradicciones, que navega los conflictos, tanto sentimentales como profesionales, según le permitan sus habilidades y le dicten sus instintos.

Según el estudio de Moretti, Rousseau aboga por el crecimiento paulatino del ser humano, masculino, por supuesto. Dicho proceso queda supeditado al control que cada individuo ejerza sobre su propia imaginación. Para Rousseau, la imaginación produce los dos errores fundamentales que impiden la ansiada madurez gradual -la intranquilidad ${ }^{37}$ y la intensidad ${ }^{38}$. Ambos, resultan en procederes prematuros, no propios de un adulto (46). Emilia, no sigue el patrón establecido por Rousseau puesto que, a lo largo de su vida manifiesta una tendencia, muy probablemente aprendida de su padre y de su tía materna, a la intranquilidad y al riesgo emocional de las experiencias intensas, lo cual para un joven adulto resultaría indeseable dentro de la filosofía pedagógica que promueve la Ilustración. En vez de “madurar” dejando atrás los supuestos impulsos adolescentes, ésta se arriesga a vivir con ellos, rechazando la moderación y la apatía adultas.

La filosofía pedagógica de Rousseau disemina todo un ideal formativo que se impuso en Europa a finales del siglo dieciocho y que posteriormente abre paso a la implantación del positivismo de Auguste Comte (tanto en Europa como en América Latina) en el siglo diecinueve y principios del veinte. En México, la ideología educativa positivista "se [oponía] radicalmente a cualquier cambio de la vida femenina que hiciera tambalear lo establecido” (Virginia Hernández Enríquez 278). A la mujer se le veía como

\footnotetext{
${ }^{37}$ Se refiere a la constante divagación del individuo, lo que impide su arraigo al entorno $\mathrm{y}$, a su vez, impide que abstraiga el significado "adecuado" de sus experiencias formativas.

${ }^{38}$ Se refiere a la tendencia a percibir demasiado significado en los acontecimientos de su entorno, lo cual produce ataduras emocionales prematuras.
} 
la protectora del hogar, sin cuyo desempeño doméstico, colapsaría el orden social. No era bien visto que la mujer demostrara interés en la participación social ya fuere en el ámbito profesional o en el político. La protagonista de Mastretta (como los demás personajes femeninos de la novela), por tanto, debe entenderse no solo dentro del contexto histórico de la Revolución, sino además dentro de la filosofía positivista que dominaba las políticas sociales y mantenía a la mujer en los márgenes de la sociedad mexicana.

En El laberinto de la soledad, Octavio Paz explica que "a pesar de lo que comúnmente se piensa, la dictadura de Porfirio Díaz es el regreso al pasado... cree en el progreso, en la ciencia...sus ideales son los de la burguesía europea” (159). Y según sugiere Paz, el porfirismo peca por partida doble puesto que no solo vuelve su mirada al pasado $^{39}$ sino que además adopta un modelo extranjero "que históricamente no le correspondía” (162). Tal y como advierten otros pensadores latinoamericanos ${ }^{40}$, la tendencia del continente del sur a importar modelos económicos y filosofías sociales que no responden a las necesidades de su pueblo mestizo termina por traicionar la promesa de los movimientos revolucionarios. La ideología positivista “ofrece una nueva justificación de las jerarquías sociales,... ya no [basada en] la sangre, ni [en] la herencia, ni [en] Dios... sino [en] la Ciencia” (Paz 160-61). Por tanto, el “disfraz positivista” del gobierno de Díaz dejó desamparados a los menos privilegiados de una forma u otra, y entre ellos a las mujeres.

${ }^{39}$ Paz arguye que esos señores ilustrados que supuestamente seguían las "ideas en boga” no eran más que "terratenientes enriquecidos".

${ }^{40}$ José Martí en "Nuestra América” y Arturo Uslar Pietri en "Notas sobre el vasallaje" son solo dos ejemplos de ello. 
Como se ha sugerido anteriormente, el entorno doméstico de la familia SauriVeytia resulta fundamental para entender el desenvolvimiento de Emilia y compararlo con el recorrido típico de los protagonistas del Bildungsroman tradicional. Con Diego Sauri, Mastretta ensaya esquemáticamente el modelo masculino de la novela de formación en un plano relativamente convencional. El suyo no es del todo un recorrido tradicional como el de la novela de formación europea sino una experiencia mexicana de formación masculina. A los diecinueve años Diego es capturado y expulsado de Yucatán a "un helado puerto en el norte de Europa" a causa de sus principios morales y de su vocación por la práctica médica. Diego se había empeñado en sanar a una mujer que había sido brutalmente golpeada por un traficante de armas, quien ocasionalmente se refugiaba de sus negocios sucios en su natal isla yucateca (10). Desde joven demuestra la inquietud característica de los héroes de las novelas de formación por salir del hogar y conocer el mundo. El período de autodescubrimiento de Diego Sauri culmina una vez que regresa a México luego de ocho años de ausencia "como quien vuelve a sí mismo y no se reconoce”, después de haber vivido en diez países y haber aprendido diez idiomas (10). A su regreso, convertido en un hombre de mundo, se casa con Josefa Veytia y, para complacerla, asienta raíces en Puebla.

La madre de Emilia, en cambio, había sido para su hija un modelo femenino de fortaleza, sabiduría y sensatez, aunque no obstante demuestra la estereotípica tendencia conservadora. A Josefa Veytia se le describe como una mujer que "siempre tenía entre los ojos hundidos y redondos una pregunta, y en el borde de sus labios la paz contagiosa de quien no urge las respuestas” (16). Es una mujer que según sugiere dicha descripción 
encarna los valores de la posmodernidad ${ }^{41}$, valores que, conjuntamente con Diego, inculcará en su hija. Es el propio Diego quien configura la percepción del lector acerca de su mujer. El matrimonio Sauri-Veytia se caracteriza por un sentido mutuo de respeto y veneración. Los primeros años de la unión resultan cruciales para el desarrollo de la filosofía pedagógica de la pareja. Es un período utópicamente dichoso para la pareja, en el cual llega a ser verosímil la conducta subversiva de la protagonista en el contexto histórico de principios del siglo XX. Diego con frecuencia compara a su esposa con la diosa Ixchel ${ }^{42}$, mientras que Josefa es consciente del "raro tesoro que hay en un hombre capaz de pedir perdón” (47). Es importante puntualizar que es inusual en la novela de formación un enfoque prolongado en los progenitores del héroe o de la heroína, hecho que sugiere la voluntad de Mastretta de alterar, tanto la estructura como los fundamentos pedagógicos que determinan la formación de la protagonista en su segundo

\section{Bildungsroman.}

Si comparásemos la relación entre madre e hija en Mal de amores con el vínculo homólogo en Arráncame la vida, tendríamos que señalar la ausencia de tensión y rivalidad entre ambas mujeres en la segunda novela. Partiendo de la explicación de Jorgelina Corbatta en cuanto a los conceptos de marianismo y malinchismo, la relación entre madre e hija en Mal de amores se puede asociar al culto de la figura de la Virgen María como símbolo supremo de lo maternal (17-18). Tanto Emilia como su madre

\footnotetext{
${ }^{41}$ Esta descripción coincide con la explicación del espíritu de la posmodernidad que ha expuesto Zygmunt Bauman, según se apuntó en la introducción de este trabajo: "the growth of knowledge expands the field of ignorance.... acquisition of knowledge cannot express itself in any other form but awareness of more ignorance” (23).

${ }^{42}$ Diosa maya del amor, la fertilidad, y la medicina.
} 
manifiestan respeto mutuo, a pesar de las diferencias generacionales e ideológicas entre ambas. Emilia no emula el modelo femenino de Josefa, mas sin embargo la honra demostrándole su admiración. La relación entre Catalina y su madre, en cambio, tiene un marcado carácter malinchista dado el resentimiento y la disfunción sentimental entre ambas mujeres. La primera heroína de Mastretta se encuentra en la disyuntiva de querer honrar a una figura materna por la cual no manifiesta verdadera admiración. Los padres de Emilia no desempeñan roles antagónicos en su crianza; ambos son fundamentales en su formación, mientras que en Arráncame la vida, la figura maternal ejerce menor influencia que el padre en la crianza de ésta.

Zygmunt Bauman explica que la toma de conciencia que supone el pensamiento posmoderno y la incredulidad hacia los metarrelatos de los que hablaba Lyotard, nos ha conducido al crudo reconocimiento de que "the journey has no clear destination" y que a pesar de ello “[we] persevere in the travel” (23). Tal y como tendrán que reconocer Diego y Josefa, “a cambio del puño de hierro de la modernidad, la posmodernidad requiere nervios de acero"43 (Bauman 24). No obstante, en Mal de amores el peso de la autoridad formativa recae sobre la figura paternal, quien anticipa los tiempos que deberá afrontar Emilia y se convierte en su gran maestro para la vida. Diego Sauri desempeña el papel crucial de fomentar en la conciencia de su hija el amor por la peligrosa libertad posmoderna y al mismo tiempo asume el riesgo de dejarse transformar, y si se quiere, educar, por la experiencia misma de criar a su hija.

${ }^{43}$ Mi traducción. 
Diego Sauri pretende hacer de Emilia una mujer independiente, y revolucionaria para su época, a pesar de las reservas de Josefa. Ante la queja de su mujer - "tienen razón mis amigas...la estamos haciendo una niña rara” Diego afirma -“Pobre criatura si la dejamos ser como las demás” (74). Emilia pone fin a la querella declarando -“Soy como las demás. Sólo que ustedes son más raros que otros padres” (74). Si se acepta la premisa de que el entorno doméstico es capaz de forjar la identidad de un individuo, Emilia no puede desarrollarse realmente como "las demás” dada la influencia que ejercen sus padres en su desenvolvimiento psíquico. Aquí es la figura del padre quien con mayor énfasis resguarda la supuesta "rareza” de su hija y su consabida actitud transgresora.

Un aspecto distintivo del segundo Bildungsroman de Mastretta es la irreverencia que muestra el padre de Emilia, mucho más que la madre, ante los presupuestos de madurez adulta que establece la sociedad. Diego simbólicamente cuestiona la legitimidad del discurso moderno que presupone una etapa de aprendizaje temporal delimitada por los años de la adolescencia tardía y la adultez temprana. En un plano literal, éste desafía dicho discurso, contraponiéndose a los temores de su mujer con respecto a la educación sentimental de Emilia. Debido a la relación que había entablado la adolescente con Daniel Cuenca, Josefa y Diego expresan su desacuerdo: -¿Qué más quieres, Josefa? ... piensa que hay cientos, miles, millones de seres humanos que jamás atisbarán el milagro en que está viviendo Emilia. -Apenas tienes diecisiete años -le recordó Josefa.

-Mejor, más tiempo tendrá para disfrutarlo.

- A saltos -lamentó Josefa.

- Porqué lo único durable es el tedio. Eso sí que permanece... (162-63). 
El tedio, como sugiere la perspectiva de Diego Sauri, es una consecuencia de la fórmula artificial por la que aboga la novela de formación tradicional. El modelo del Bildungsroman convencional no tolera que el héroe se "salte" etapas o mantenga relaciones románticas definitivas antes de culminado el proceso de aprendizaje y maduración. Diego se muestra en oposición a la mesura, propia de la modernidad, por la que aquí aboga Josefa. Es preferible el riesgo emocional de la desilusión amorosa e incluso el vínculo emocional subversivo, como es el caso de Emilia, a la imperturbabilidad emocional propia de la modernidad. Con esto no solo se explica la aceptación paternal que moldea el desenvolvimiento de Emilia, sino que además se percibe el efecto que ésta ejerce en la “formación” de sus padres.

Uno de los aspectos característicos del Bildungsroman tradicional es el alejamiento entre el héroe y sus padres, y más concretamente su padre. Como explica Buckley, dicho distanciamiento en ocasiones ocurre con la muerte del padre biológico, y en tal caso el héroe se ve obligado a buscar una figura paterna suplente (19). Esto provoca que el protagonista corte las ataduras infantiles y logre hacer valer su propia independencia adulta. En Mal de amores, Mastretta invierte la tendencia al desarraigo y plantea un nuevo modelo de desenvolvimiento personal. Emilia no se ve obligada a escapar del ambiente doméstico puesto que su relación con sus padres se basa fundamentalmente en la reciprocidad instructiva que pueden ejercer los padres así como el valor formativo que tienen los hijos para los padres. No se trata, pues, de erigir una identidad a partir de la desvinculación con la casa, sino más bien de forjar una relación de aprendizaje mutuo basado en la complicidad y la continuidad de los valores familiares. 
La selección del colegio al que asistiría Emilia fue motivo de conflicto en la familia Sauri-Veytia. Diego se negó a que la niña estudiara en un colegio religioso ya que según él “ahí lo único que le enseñarían son rezos y de lo que se trata es de formar una criatura que se entienda con las antinomias del mundo moderno"44 (62). Al final decidieron inscribirla en "el colegio de una solterona severa y puntillosa que guardaba consigo una historia de amores prohibidos”; en otras palabras no es una maestra moralmente modelo, sobre todo si se le compara con la alternativa pedagógica del colegio religioso (62). La mujer del nuevo siglo debía recibir una educación laica y debía saber de “política, viajes, y medicina”, conocimientos en que Diego instruye a Emilia en las tardes después de que sale del colegio (62). A pesar de las quejas conservadoras de Josefa, Diego se ocupa de que Emilia conozca tanto de la medicina occidental como de antiguos remedios naturales, tanto de su país como del mundo más allá de sus fronteras, tanto de la fe cristiana como de diosas mayas, aztecas y grecolatinas.

Con el nacimiento de Emilia en 1892, Diego Sauri asume la responsabilidad de criar a una mujer que, en sus palabras, “vivirá en otro siglo” (76). Éste se niega a que Josefa le hable a Emilia de las novelas de Charlotte Brontë, quien escribiera una de las primeras muestras del Bildungsroman femenino ${ }^{45}$. Aquí Mastretta pone distancia entre su

\footnotetext{
44 De acuerdo con María Inés Lagos, en el relato de formación femenina latinoamericano, "la religión católica juega un papel de primera importancia en la educación de las protagonistas y en la configuración de la subjetividad femenina”. En el colegio católico las niñas son instruidas en el ideal mariano, que en oposición al machismo, les enseña a sentirse espiritualmente superiores a los hombres porque pueden controlar sus instintos sexuales de un modo que no pueden hacerlo fácilmente los varones debido a sus “debilidades” (96-97).

45 Jane Eyre (1847). Según Franco Moretti la novela de formación inglesa es en el fondo un cuento de hadas. Ésta se caracteriza por su estabilidad, conformidad, y por el orgullo
} 
protagonista y el modelo clásico de Brontë. El Bildungsroman inglés y Jane Eyre en concreto, según Moretti, se mostró incapaz de lidiar con el tema del adulterio. El mundo de la novela de formación inglesa está repleto de "ethical dichotomies [and] cannot tolerate the thought of an ambiguous situation, suspended between two value-systems, two persons, two lives” (188). Con Emilia Sauri, Mastretta asume el reto de lidiar abiertamente con la problemática del adulterio y la dualidad moral femenina dentro del contexto cultural e histórico mexicano.

El padre se niega además a que la niña esté expuesta a otros textos clásicos de la literatura europea, o al menos no sin su debido filtro crítico. Le aterra que Emilia asimile los postulados anticuados de conducta femenina que modelan las novelas del siglo diecinueve. De acuerdo con el proyecto educativo de Diego "los avatares de Julián Sorel o las penas de Ana de Ozores ¿qué le interesan [a Emilia]?” y defiende su perspectiva arguyendo que él "por lo menos le cuent[a] la realidad” (26). Como apunta Marianne Hirsch, el protagonista de la novela de formación tradicional hace propios el espíritu y los valores de la sociedad en la cual se desarrolla (297). Y la novela misma, en su faceta pedagógica, convierte a los héroes de la narración en modelos formativos con motivo de diseminar dichos valores en la comunidad de lectores. Conocedor de la vulnerabilidad propia de la juventud de Emilia, Diego se dispone a contrarrestar el efecto de los patrones educativos que difunde el Bildungsroman tradicional.

Diego, al igual que el padre de Catalina en Arráncame la vida, adopta el papel de defensor de la individualidad de su hija. Como ha notado Jane Elizabeth Lavery, en

de los ingleses de tener "a solid world, sure of itself and at ease in a continuity that fuses together 'tradition' and 'progress"”. Véase The Way of the World, 181, 185. 
ambas novelas "the traditional mother-daughter relationship is subverted... with the closer bond with the father” (93). No obstante, ambos modelos paternales difieren significativamente. El padre de Catalina carece de la libertad intelectual que le inculca Diego Sauri a su hija. Asimismo, aquél es una figura paternal desautorizada y desmoralizada por Andrés Ascencio, mientras que éste, sin perder la docilidad que lo caracteriza, es un ejemplo de autoridad y autonomía intelectual. Don Marcos Guzmán queda simbólicamente desmasculinizado debido a las humillaciones que padece a manos del general Ascencio, empezando por la desfachatez con que le obliga a ceder la mano de su hija. El padre de Emilia constantemente rechaza el modelo de masculinidad tradicional, y redefine así su propia masculinidad. Ejemplo de ello se encuentra en su ecuanimidad ante asuntos que estereotípicamente provocan reacciones agresivas. Tanto en momentos de crisis familiar como política, Diego muestra una actitud más bien pasiva y siempre reflexiva. Su caracterización, por lo tanto, legitima su autoridad y su influencia en cuanto al desarrollo psíquico de Emilia.

Jerome Buckley argumenta que la relación entre padres e hijos en el Bildungsroman clásico es notablemente problemática. Afirma que la familia, y en concreto la figura del padre "proves doggedly hostile to his creative instincts or flights of fancy" de modo que al joven no le queda otra alternativa más que abandonar "the repressive atmosphere of home” para iniciar su verdadera educación, fuera de casa (17). Sin embargo, en Mal de amores, dicho patrón queda radicalmente subvertido. A lo largo de toda su vida, Emilia no encuentra en ningún otro sitio la paz y la aceptación con las que creció en la Casa de la Estrella. Su primer hogar, lejos de ser el espacio hostil del Bildungsroman clásico, se convierte en una insuperable edad dorada. A Emilia "le 
gustaba tanto su padre que no necesitó desafiarlo jamás”, mientras que Diego “encontraba a Emilia tan perfecta y adorable como el futuro que tanto le gustaba predecir” (Mastretta 96). Diego Sauri, lejos de obstaculizar el desenvolvimiento de su hija, se encarga de cultivar su creatividad y sus aspiraciones. Es él quien primero la libera de la represión e imposiciones patriarcales de la sociedad en la que crece, desafiando incluso las tendencias más conservadoras de Josefa.

Dentro de la crítica de la novela de formación femenina en América Latina, se han expuesto principios similares al que explica Buckley. Según Leasa Y. Lutes, “el papel del padre, por necesario que sea en el mundo prosaico, no demuestra ese nexo espiritual que nace entre madre e hija” (23). En cambio, la Emilia Sauri que conocemos sería inconcebible sin el profundo "nexo espiritual” que existe entre padre e hija. La explicación de Lutes se basa en el argumento de que la educación tiene un importante componente imitativo, lo cual sugiere que los modelos de las heroínas en la novela de formación femenina hispanoamericana deberían ser también mujeres. De hecho, esto ocurre en una mayoría de los textos del género. Las obras representativas de Isabel Allende, Rosario Castellanos y Carmen Boullosa son algunos ejemplos. No obstante, en ambas novelas de Mastretta, la figura paternal cobra un protagonismo formativo inusual en el género. Catalina y sobre todo Emilia le deben mucho de lo que son intellectual y sentimentalmente a sus padres.

En cuanto a la caracterización de los padres, tanto en Arráncame la vida como en Mal de amores, la propia autora ha explicado en reiteradas ocasiones que las figuras paternales en ambos textos tienen un marcado carácter autobiográfico. En su entrevista con Bárbara Mujica, Mastretta corrige a la entrevistadora, quien comentaba que Emilia 
Sauri era una mujer afortunada por haber conocido a dos hombres excepcionales. La escritora interviene -“let’s say three. She found three exceptional men. The most exceptional was her father. I should tell you that I constructed Diego as an homage to my own father” (40). El acercamiento de Mastretta a la estereotípica problemática padre-hija propone un evidente cuestionamiento de la normativa que generalmente presentan las novelas de formación femenina. Por una parte propone que no hay que aceptar que las dificultades en el proceso formativo de mujeres se deban al trauma de un fracasado vínculo entre padres e hijas. Tampoco hay que suponer que una casi utópica relación entre padres e hijas inocule a las mujeres de conflictos interiores en sus recorridos formativos.

\subsection{VIDAS REVOLUCIONARIAS Y REVOLUCIÓN: REPLANTEAMIENTOS HISTÓRICOS E INCLUSIÓN FEMENINA}

En 1994, poco antes de la publicación de Mal de amores, Mastretta explica como el contexto revolucionario mexicano determina, justifica y hace verosímil el desarrollo de la protagonista de su segunda novela:

My character is a woman who has the attitudes of the seventies in 1910, something quite possible because the period of the Revolution from 1910 to 1940 was rather permissive. It produced change, was prosperous, and very vital...Those years turned things around in such a way that a woman who didn't marry, for example, didn’t have to be an embittered old maid. She could be a woman with various passions, with a public and private 
personal life governed neither by local institutions nor social norms. (Gabriella de Beer 17)

Para Mastretta la Revolución ofrece la posibilidad de narrar el período de transformación política y social desde la perspectiva femenina. Durante el período revolucionario, arguye la escritora, la mujer goza de libertades y oportunidades que no se tolerarían en épocas conservadoras. Los cambios estructurales en el gobierno entre 1910 y 1917 así como las décadas posteriores de institucionalización y reforma facilitan, a nivel histórico, la liberación y participación femenina en dicho período de transformación social. En el plano literario, la revolución favorece la verosimilitud de la conducta de las mujeres en Mal de amores, particularmente de la heroína y su tía, Milagros Veytia.

La llamada novela de la Revolución Mexicana otorgó siempre un espacio protagónico a figuras masculinas, a partir de las cuales se articuló todo un discurso de identidad histórico nacional. Muestras de ello pueden encontrarse tanto en la narrativa de escritores contemporáneos con la Revolución como es el caso de Los de abajo (1916) de Mariano Azuela como en la de escritores posrevolucionarios cuyo ejemplo más reconocible se halla en La muerte de Artemio Cruz (1962) de Carlos Fuentes. Las mujeres estuvieron fundamentalmente ausentes en el corpus de la novela de la Revolución hasta que escritoras como Elena Garro, Rosario Castellanos y Ángeles Mastretta, entre otras, se dieron a la tarea de visibilizar la presencia femenina en dicho contexto histórico. Los personajes de estas y otras narradoras mexicanas "no sólo [re]definen lo que es mexicanidad -desde su perspectiva femenina, por supuesto -sino que también ponen en tela de juicio los medios por los cuales dicha nacionalidad se ha definido minimizando consistentemente los valores femeninos” (Carmen M. Rivera 
Villegas 39). Con sus respectivas aportaciones a la historiografía de la novela de la Revolución, estas novelistas han desempeñado la subversiva labor posmoderna de revisar, desacralizar y revalorar los discursos legitimadores que tradicionalmente han suprimido el rol de la mujer en la sociedad y las historias nacionales.

Adoptar el modelo del Bildungsroman para replantearse la experiencia formativa misma dentro del contexto histórico de la Revolución, presupone, siguiendo la lógica de Hutcheon, un juego paródico que se lleva a cabo desde el centro u origen del género clásico. Con Mal de amores, Mastretta adopta una actitud contestataria al proponer una revisión del desempeño femenino tanto en el ámbito personal y privado como en la esfera social. Entre las estrategias narrativas que emplea se destaca la de enmarcar la narración en un contexto de permisividad que según la autora impregna todas las esferas sociales e individuales durante las épocas revolucionarias. A la luz de dicho trasfondo histórico la novela confronta los discursos hegemónicos del proyecto de la modernidad, dentro de cuyos paramentos la conducta subversiva de Emilia sería impensable. Los personajes revolucionarios que cobran vida en el texto suponen una revaloración de los desgastados metarrelatos de la modernidad en cuanto al proceso mismo de formación. Así Mastretta, apropiándose y parodiando la forma convencional del género, se permite cuestionar los presupuestos del mismo, al tiempo que desarticula las representaciones oficiales del pasado.

En las tertulias que tienen lugar en la casa de los Sauri y del doctor Cuenca se dan cita hombres y mujeres activistas para debatir los disturbios de la guerra. Mastretta ejerce una voluntad de dar protagonismo a la labor femenina y a la colaboración entre ambos sexos en las reuniones clandestinas en torno al movimiento anti-reeleccionista. Es en este 
entorno liberal en el que Emilia crece y desarrolla sus propias ideas políticas. Su tía, Milagros Veytia es una mujer desafiante del orden patriarcal que "prefirió negarse al matrimonio antes que abandonar lo que juzgaba el privilegio de vivir como los hombres” (35-36). Ésta deliberadamente introduce a su pequeña sobrina al espacio intelectual típicamente reservado a los hombres. Durante una de tantas tertulias, Milagros se “encargó de que [Emilia] recorriera el salón levantada por el aire” para que aprendiera a pertenecer al mundo de los hombres (35). Tales exposiciones del dominio intelectual masculino, del cual se excluye sistemáticamente a los niños, particularmente a las hembras, sirve de fundamento para la formación de su propia individualidad. Vivir como "los hombres” para Emilia implica luchar por sus ambiciones profesionales, viajar al extranjero, y desobedecer las convenciones de fidelidad femenina dentro de la sociedad tradicional mexicana.

Con el personaje de Milagros, Mastretta pone en marcha un juego intertextual entre la tía subversiva y la figura de Sor Juna Inés de la Cruz ${ }^{46}$. Tanto la una como la otra se ven (dentro del texto y desde una perspectiva histórico-literaria) como madres intelectuales, mujeres modélicas y promotoras de la inclusión femenina en todas las esferas de la sociedad. La tía Milagros es una de las "historiadoras comunales y nacionales” que, según Rivera Villegas, se encargan de “feminizar el espacio histórico

\footnotetext{
${ }^{46}$ El concepto de intertextualidad según lo propone Julia Kristeva, quien a su vez elabora el concepto de dialogismo de Bajtín, entiende el texto como una entidad dinámica y abierta en el cual se intersectan significados múltiples. María Jesús Martínez Alfaro expone que "the concept of intertextuality, requires... that we understand texts not as self-contained systems but as differential and historical, as traces and tracings of otherness, since they are shaped by the repetition and transformation of other textual structures.” (268).
} 
nacional, el cual ha sido construido, representado y sacralizado por [las] sociedades patriarcales” (37-38). Milagros posee un carácter revolucionario en el sentido literal debido a su activismo y participación políticos. No obstante, su caracterización es vital para la representación de la mujer que, asimismo, se comporta revolucionariamente fuera del contexto social y político. El paralelo entre Milagros y Sor Juana se reitera en la pasión de ambas mujeres por la poesía. De hecho, en su discurso de recepción del premio Rómulo Gallegos ${ }^{47}$, Mastretta rinde homenaje a Sor Juana, elogiando el "Primero sueño” como “el más grande de sus poemas”, en el cual la poetisa barroca se proponía “comprender todas las cosas de que se compone el universo” (199). Como Sor Juana, Milagros Veytia:

Tenía su libertad como pasión primera y su arrojo como vicio mejor. Solía desbaratar un argumento con la luz ominosa de su mirada despreciándolo, y era lectora como pocas y erudita como ninguno. Le gustaba desafiar a los hombres con el acervo de sus conocimientos científicos y se divertía memorizando poemas y buscándose retos. (22-23)

Así como Mastretta se nutre de la lumbre intelectual que representa Sor Juana para la cultura hispanoamericana, Emilia, similarmente, se forma intelectualmente con la guía e influencia de su tía Milagros.

Aparecen citadas en Mal de amores dos obras de Sor Juana. El poeta Rivadeneira, quien desea mantener con Milagros una relación amorosa tradicional, bromea con

${ }^{47}$ El premio es concedido a Mal de amores en 1997, y el discurso es recogido en la colección de ensayos titulada El mundo iluminado. 
Milagros al verla con “un niño en cada brazo” y, conociendo bien su negativa al matrimonio y a la maternidad, le recita dos versos del auto sacramental de Sor Juna, El cetro de José (1692) - “¿Qué te parece, Lucero / la fuerza de mi desdicha?” A lo que Milagros replica con otra cita de la poetisa mexicana - “A no tener mi valor pienso que el vuestro envidiara”, esta última perteneciente a Amor es más laberinto de 1689 (36). Como explica Linda Hutcheon, "postmodern intertextuality is a formal manifestation of both a desire to close the gap between past and present of the reader and a desire to rewrite the past in a new context” (118). En este intercambio, Mastretta satisface ambos propósitos expuestos por Hutcheon, entablando así, un diálogo con los textos del pasado mexicano. Por una parte otorga vigencia a la poesía sor juanesca colocándola en un contexto doméstico, personal y hasta lúdico. Y por otro lado, consigue reescribir la consabida elección de Sor Juana entre el matrimonio y el convento. Con esto "reivindica el derecho de la mujer [moderna] a contraer o no matrimonio según su voluntad, sin que por ello se le estigmatice socialmente, o se le compadezca” (Molina Sevilla de Morelock 161). A través de Milagros inscribe la experiencia intelectual femenina de Sor Juana en un nuevo contexto, el de la mujer revolucionaria de finales del siglo diecinueve y principios del veinte.

Además de la crucial influencia formativa de Milagros en Emilia, esta última goza de toda una comunidad que sustenta su crecimiento personal e intelectual y la cual está compuesta principalmente por hombres. La confección de una novela de formación femenina en la que abunden modelos formativos masculinos es un hecho, no solo inusual, sino revolucionario en sí mismo. A continuación se examinarán dichas figuras masculinas con la intención de explorar el efecto que tienen en el desenvolvimiento de Emilia y a su 
vez indagar en la subversión formal que esto supone para el modelo del Bildungsroman. Dichas figuras son: su padre (Diego Sauri), el doctor Octavio Cuenca, el doctor Hogan, el doctor Zavalza y, en menor grado, Daniel Cuenca -todos figuras masculinas que contribuyen a fomentar el desenvolvimiento tanto personal como profesional de Emilia. Algunos, especialmente Diego, resultan particularmente decisivos en el desarrollo de su temprano interés por el conocimiento científico y la práctica médica, tanto la occidental como la indígena.

El mundo de la medicina profesional era prácticamente un campo de estudio vedado a las mujeres de principios del siglo veinte, época en que Emilia entra en edad universitaria y manifiesta intenciones de desenvolverse profesionalmente en dicho campo. No obstante, ésta se convierte nada menos que en discípula indirecta de Elizabeth Blackwell, reconocida como la primera mujer estadounidense en recibirse de médico en 1849. En la novela, Blackwell había sido profesora del Dr. Hogan, quien a su vez recibe a Emilia en Chicago y le permite avanzar en sus conocimientos de medicina. Blackwell, el personaje histórico, había llegado a interesarse por la medicina al enterarse de que una amiga, quien padecía de una enfermedad ginecológica, se negaba a consultar un médico por vergüenza de ser atendida por un hombre. Como era de esperar, Blackwell enfrentó una oposición rotunda por parte de las autoridades universitarias y se le denegó la admisión en repetidas ocasiones hasta que finalmente se le permitió matricular en el Geneva Medical College de Nueva York (Rodríguez-Pimentel 636).

En México, Matilde Montoya fue la primera mujer en graduarse de médico en 1887, pese a un sinnúmero de obstáculos y difamaciones machistas que se le interpusieron. Quienes se oponían a la participación de las mujeres en la profesión 
médica argüían que era "perversa la mujer que quiere estudiar medicina, para ver cadáveres de hombres desnudos” (Jaramillo-Tallabs 72). A pesar de haber terminado sus estudios, le impidieron presentar el examen final por el hecho de ser "alumna”, cuando el reglamento del colegio solamente otorgaba tal derecho a los "alumnos". No fue hasta que el presidente Porfirio Díaz cambió el estatuto de la Escuela Nacional de Medicina para permitir a las mujeres graduarse de medicina, que Montoya pudo recibirse ${ }^{48}$. Dicha intervención debe considerarse excepcional, ya que como se explicó en el capítulo dedicado a Arráncame la vida, durante el porfirismo la educación femenina se vio disminuida. Los importantes aunque limitados avances que sí se lograron a comienzos del siglo veinte se debieron principalmente a la presión que ejercieron sobre el gobierno algunas mujeres de la clase media (Elizabeth Pearson 75). Es importante subrayar que las mujeres pobres seguían padeciendo las privaciones educativas instituidas por el estado porfirista.

Existían voces contemporáneas de disensión en cuanto a la exclusión sistemática de la mujer del saber científico. Con respecto a la educación de la mujer en América Eugenio María de Hostos, influido por la filosofía positivista de Augusto Comte y Herbert Spencer, aboga desde 1873 por la instrucción científica de la mujer. Para el escritor puertorriqueño la exclusión de la mujer del ejercicio intelectual es profundamente perjudicial para las estructuras sociales y políticas de América Latina. En su ensayo "La educación científica de la mujer” arguye que cuando se le impide a la mujer acceder a una educación científica y racional se convierte "en una planta que vegeta, no una

\footnotetext{
${ }^{48}$ Como explica Jaramillo-Tallabs, Matilde Montoya recurrió al presidente Díaz en más
} de una ocasión, escribiéndole varias cartas en las que solicitaba su intervención. 
conciencia que conoce su existencia” (38). Intenta convencer al lector de semejante propuesta haciéndole ver que es ley natural la igualdad moral y de facultades intelectuales entre la mujer y el hombre puesto que "la mujer, como el hombre es obrero de la vida” y que al educar a la mujer científicamente se fortalecen lo cimientos de la familia nuclear y la sociedad de la jóvenes repúblicas hispanoamericanas (39). Su argumento opta por la retórica progresista y pragmática con el fin de hacer llegar a sus lectores un mensaje humanista de justicia.

En 1929 Virginia Woolf propuso que "una mujer debe tener dinero y una habitación propia” para poder dedicarse plenamente a la profesión de su elección, en este caso la de escritora (Woolf 6). Para Emilia Sauri, quien decididamente goza de los privilegios de pertenecer a la clase media, los estudios de medicina le conceden la ansiada independencia intelectual, usualmente negada a la mujer. Asimismo, la imagen de la mujer médico refuerza la presencia femenina en los ámbitos profesionales de México a principios de siglo. El acceso a la educación liberal y el apoyo de sus mentores (casi todos hombres) supone una ruptura con el rol doméstico de la mujer en la sociedad mexicana, y a su vez evidencia un distanciamiento intelectual con respecto a la Catalina de Arráncame la vida, quien se mantiene dentro de los parámetros educativos accesibles a la mujer. La educación de Emilia concuerda con las estipulaciones rousseaunianas para la formación de los varones, no de las mujeres. Su lucha por la autonomía profesional la coloca en un plano intelectual equivalente al masculino, lo cual fomenta su independencia a un nivel social y, en lo personal, informa su liberación moral.

Diego Sauri, si bien un apasionado del conocimiento médico, es a la vez un individuo escéptico del discurso cientificista y eurocéntrico de la modernidad positivista. 
Concibe el conocimiento médico no como una verdad irrefutable, sino como una “racionalidad imperfecta” (61). Cuando Emilia contrae la viruela ${ }^{49}$, el asunto del tratamiento que debían administrarle a la niña genera un debate entre Diego y Josefa. Diego dispuso que la bañasen con yerba mora mientras que a Josefa le preocupaba el remedio ya que, según las convecciones curativas del momento, estaba prohibido el baño a los contagiados de ese padecimiento. El padre, confiado en los conocimientos de toda una vida de investigación herbaria ${ }^{50}$, asegura que "hacen más por la medicina quienes buscan que quienes concluyen”, y con esto desecha las supuestas certidumbres infalibles de la medicina ortodoxa contemporánea, a la vez que convence a Josefa de ir en contra de la convención médica del momento (61).

El padre de Emilia transmite a su hija su dedicación y respeto por la sabiduría medicinal indígena. El padre biológico es también su maestro de medicina natural y de los antiguos métodos curativos mayas. Es él quien, simbólicamente, al tiempo que le lega su composición genética, le ofrece también su herencia cultural y su inmenso amor por la cultura yucateca. Jane Elizabeth Lavery explica la influencia que ejercen en la formación profesional de Emilia los individuos masculinos que la rodean. Diego "enlightens her about the intricacies of alternative medicine, such as indigenous herbal medicine, [while] Cuenca... Antonio Zavalza [and Hogan provide] practical instruction in orthodox medicine” (93). Todos, vale enfatizar, hacen uso en sus respectivos procedimientos

${ }^{49}$ La enfermedad pareciera ser una reacción física a la separación de Daniel Cuenca cuando éste es internado en un colegio en Chalchicomula.

${ }^{50}$ Recordemos que el viaje de bodas de los Sauri-Veytia "había sido un largo itinerario en busca de yerbas medicinales." 
curativos, tanto del conocimiento de la medicina occidental como de la tradición curativa de yerbas y otros métodos no aceptados dentro de la convención médica europea.

Una de las razones por las que Diego no se deja convencer fácilmente por los discursos cientifistas del momento es su amplio conocimiento de la historia de la medicina. Uno de los “héroes” del boticario es el médico sevillano Nicolás Monardes, quien en 1574 publicara la Historia medicinal de las cosas que se traen de nuestras Indias Occidentales. Monardes, curiosamente, nunca estuvo en América sino que cultivaba y estudiaba en su propio huerto las plantas que le traían del Nuevo Mundo. Emilia recibe de su padre una antigua copia del libro y, al darse cuenta que algunas de las preparaciones farmacéuticas (supuestamente originales) de la botica de Sauri ya se habían registrado en el estudio del médico español, solicita una explicación al padre, quien simplemente replica -“Es original nuestra porque ya nadie la usaba. Y el tiempo es el mejor amigo de la originalidad” (176). Para Diego no hay conflicto alguno entre las nuevas metodologías médicas y los estudios antiguos. Se hermana en él la pasión por el conocimiento histórico y la búsqueda por el conocimiento médico actualizado. Reconoce que lo que hoy se considera medicina moderna ni es permanente ni debe desmerecer las contribuciones de investigadores predecesores.

El doctor Cuenca es para Emilia un padre intelectual. Si bien su padre biológico le inculcó desde pequeña la pasión por el conocimiento científico, el doctor Cuenca es quien más concretamente comparte con Emilia los loables ideales del ejercicio de la medicina moderna, y quien la acoge bajo su tutelaje para guiar su desenvolvimiento profesional. Según establece el juramento hipocrático (en su versión original y otras variaciones contemporáneas), los lazos entre el maestro y el aprendiz de medicina son equivalentes, 
en lo profesional, al vínculo sanguíneo entre hijos y progenitores. El antiguo juramento dispone como primer compromiso del médico principiante "venerar como a mi padre a quien me enseñó este arte”. El propio Diego reconoce, sin resentimiento alguno, la estrecha relación que tienen su hija y el doctor Cuenca y la complicidad entre ambos en cuanto a las intenciones académicas de la muchacha. Luego de enterarse de que Cuenca, como buen clínico, había guardado el secreto de Emilia de estudiar medicina (por cuenta propia) y dejar las clases de chelo, éste se dirige al médico amigo y le confiesa: “Me siento como un cornudo... se le va a hacer a usted el sueño de tener una hija doctora”; a lo que Cuenca contesta: “Ojalá y fuera mi hija” (201).

Si alguien resiente la relación profesional entre Emilia y el doctor Cuenca es Daniel Cuenca. Éste se da cuenta de que Emilia comparte con su padre una intimidad intelectual que él desconoce. Daniel parece incomodarse al presenciar la autonomía de Emilia y su capacidad para ocuparse de asuntos no relacionados con su relación romántica. Luego de que el doctor Cuenca solicita la ayuda de Emilia para atender a un herido que protestaba en contra de la dictadura porfirista, Daniel experimenta celos por el apego entre su padre y su mujer:

Vio después a su padre y a Emilia entregarse a la pasión que ambos compartían. Pasó entonces de sentirse el centro en la vida de... Emilia... a ser tan sólo un testigo intruso en ese universo de signos y términos que no sólo desconocía sino que le provocaron las primeras convulsiones de un sentimiento que hasta ahora desconocía: los celos lo fueron enfureciendo mientras su padre y Emilia tejían en sus narices la red de complicidades 
más perfecta... Su padre y su mujer sabían de sí mismos cosas que el desconocía, compartían un lenguaje que no lo involucraba... (206-07) Bajo los efectos emocionales de los celos, Daniel presupone que su padre le tiene a Emilia un cariño que jamás le mostró a él. Le incomoda que "Emilia quería a otro Cuenca además de a él y [que] su padre quería a Emilia como nunca demostró quererlo a él” (207).

A pesar de la connotación melodramática del título de la novela y sus innegables manifestaciones textuales, también conviene puntualizar que Mastretta deposita en Emilia el raciocinio crítico típicamente asociado con los hombres. La joven Sauri-Veytia es capaz de poner a un lado su propia turbulencia sentimental a fin de alcanzar sus objetivos profesionales. No solamente "quería a otro Cuenca” sino que también quería, para el pesar de Daniel, dejar México e ir a estudiar medicina a Chicago. “—Yo no voy a cambiar de planes. Estoy cansada de ir y venir según el vaivén de tus antojos y los de la república”, le confirma desafiante a Daniel (293). La joven se aferra a una verdad individual, su verdad, la cual no está dispuesta a abandonar por seguirle los pasos al amante.

En los Estados Unidos el doctor Hogan, antiguo amigo de su padre, es quien la ayuda a establecerse en la ciudad norteamericana. Tal y como ocurre con el doctor Cuenca, el doctor estadounidense trata a Emilia como a una hija: "la acogió... bajo los frascos de su refugio y el desamparo de su reciente viudez, con un cariño mezcla de voluntad paterna y pasión juvenil” (297). Bajo su protección se inscribe como oyente en la universidad de Northwestern, donde empieza a adentrarse formalmente en el mundo de la medicina profesional. 
La estadía en Chicago le da a Emilia la perspectiva que convencionalmente proporciona el motivo del viaje en la novela de formación. No es ésta la típica huida de casa del héroe del Bildungsroman tradicional, en la que el personaje pretende alejarse de los modelos formativos de la infancia. La escapada de Emilia es parte de su proyecto personal que nada tiene que ver con el rechazo al lugar de origen. De hecho, al arribar a Chicago, el frío y la soledad le hacen cuestionar su decisión de dejar México: “¿qué hacía... nacida para su bien en las tibiezas de un país tropical, rendida sobre un charco de nieve sucia, harta, cansada y sola como nunca pensó que sabría estar? ¿Qué buscaba si bajo las estrellas de su casa tenía el lugar más tibio y grato del mundo? ¿Ser médico?” (297). Desde allá, aprende a vivir lejos de la comodidad de su hogar y fortalece su sentido de autonomía. La fría ciudad norteamericana es un lugar de aprendizaje, tanto del conocimiento médico y de sí misma, como del mundo más allá de su Puebla natal. A través de este recorrido formativo, puede percibir la devastación producida por los conflictos revolucionarios, con una claridad y perspectiva que difícilmente poseería de no ser por la distancia.

En compañía de Daniel y de su tía Milagros, Emilia experimenta por primera vez el trabajo logístico de la Revolución a un nivel personal. Como explica Molina Sevilla, salvo en una pocas ocasiones, Emilia "vive la revolución a través de los periódicos, de los relatos de Daniel, y de las angustias y tertulias de sus familiares y amigos” (153). En esta primera ocasión se disponían a distribuir propaganda maderista en el pobre barrio poblano de Santiago, "un lugar que acunaba las viviendas de adobe y tierra, la desesperanza y el lodo de familias muy pobres” (140). Ante la incomodidad que experimenta al ver el espectáculo de la pobreza más brutal, Emilia siente “vergüenza y 
culpa”, puesto que jamás había salido del privilegiado "centro luminoso de la ciudad" (141). Su reacción resulta un tanto inesperada y contradictoria, especialmente si se toma en cuenta su crianza al lado de Milagros ${ }^{51}$ y su heredada vocación para las labores curativas por la línea paterna. No obstante, así comienza a darse cuenta de la imprescindible contribución de las mujeres a la revolución y de las aportaciones que ella misma puede ofrecer a la sociedad en base a sus conocimientos médicos.

Los héroes (y villanos) de la revolución mexicana son casi exclusivamente hombres. Es común encontrar exaltada en las historias oficiales de esta etapa formativa la labor ideológica de los hombres del período revolucionario. En cambio, el trabajo de las mujeres usualmente queda relegado a historias más recientes dedicadas a la participación revolucionaria femenina, con el fin de dar su debido lugar a las importantes aportaciones de la mujer mexicana en la era revolucionaria. Como explica Anna Macías, numerosas mujeres (mayormente de la clase media) participaron en la revolución de varias maneras: "they gave money to various revolutionary groups and engaged in a number of undercover activities, including the gathering of arms and ammunition, expediting letters, and passing on information to the revolutionaries... [A] number of women [also] served as nurses on the battle fields and behind the lines" (39).

Emilia, sin tener título de medicina, hace uso de sus conocimientos médicos para atender "unas veces, a las víctimas de batallas caseras con el ejército porfiriano; y, otras, a los heridos que venían directamente del enfrentamiento villista o zapatista” (Rivera Villegas 41). Resulta evidente que a pesar de la exaltación convencional del activismo

\footnotetext{
${ }^{51}$ Emilia se horroriza al ver la naturalidad con que su tía se acerca a las personas pobres y enfermas (Mal de amores 141).
} 
masculino en la revolución, el trabajo de las mujeres fue igualmente crucial para el proyecto revolucionario. Al ver a Emilia ejercer la cruda labor médica, Daniel reconoce que su trabajo posee incluso mayor importancia que el suyo propio. Reconoce que ella “era más fuerte que él, más audaz que él, menos ostentosa que él, más necesaria en el mundo que él con todas sus teorías y todas sus batallas” (320). La fe idealista de Daniel al final lo defrauda ${ }^{52}$. El trabajo pragmático de Emilia, por una parte, tiene un valor que trasciende la lucha del momento y, al mismo tiempo, resulta fundamental para la subsistencia de la revolución.

El episodio con el cual se da inicio a la revolución adquiere un significado particular dentro del enfoque teórico de este trabajo. La ficción historiográfica de Mastretta problematiza el inicio de la década más estudiada de la historia de México. El narrador afirma que "la revolución no empezó el 20 de noviembre a las seis de la tarde, pero empezó” (218). Lo más importante por recalcar aquí es que Mastretta subvierte el discurso de la revolución, situando su origen, no en el espacio masculino y público de la fecha oficial, sino dos días antes, en el espacio doméstico de Carmen Serdán ${ }^{53}$. Se posiciona a la figura femenina, invadida en su propio domicilio, como defensora de los ideales democráticos y anti-reeleccionistas. Es a un mismo tiempo agredida y agresora ya que, al verse cercada por la policía federal, ésta se le atraviesa en el camino, apuntándole al oficial con un arma de fuego, a fin de darle tiempo a su hermano y a otros de

\footnotetext{
${ }^{52}$ Madero no resultó ser “el gobernante justiciero que todos esperaban” (Mastretta 282).

${ }^{53}$ Carmen Serdán era una de los líderes de la campaña presidencial de Francisco Madero. Su casa fue atacada el 18 de noviembre de 1910 por el ejército federal debido a las sospechas que se tenían de su participación en el alzamiento en Puebla.
} 
parapetarse en la azotea de la vivienda. (219). La revolución, arguye Mastretta, comenzó no con el levantamiento del Plan de San Luis ${ }^{54}$, sino con la manifestación del coraje guerrero de Carmen Serdán.

A través de su recorrido como aprendiz de médico, Emilia además se enfrenta con la cruda realidad de otras mujeres, las más pobres y olvidadas por el gobierno, mujeres que la hacen resentir su propio privilegio y la solidarizan con las comunidades que más brutalmente padecen los altibajos de la revolución. En su desempeño como ayudante en la farmacia de su padre, Emilia conoce en el barrio de Xonaca a una de esas mujeres, tan pobre que no puede adquirir el remedio para su hijo moribundo. La joven boticaria recuerda que "la muchacha le contó cosas que [ella] trató de olvidar [porque] esa mujer tenía sólo dos años más que ella y no había visto sino abandono y hambre, infamias y maltrato” (242). Debido a una complicación obstétrica durante el sexto parto de la muchacha, Emilia acude a su auxilio, demasiado tarde para salvarle la vida. En su impotencia, Emilia "lloró por la amistad que no tuvieron [y] por las distancia de sus mundos” como quien maldice el privilegio del médico impotente que sufre la pérdida de un paciente (245).

El doctor Antonio Zavalza conocía mejor que nadie la sensación de impotencia que vivía Emilia. Intenta consolarla asegurándole que "los médicos inmunes son pésimos médicos”, y que su frustración ante las limitaciones de la medicina era una respuesta natural de todo buen clínico (249). Zavalza se había trasladado a Puebla y casi de inmediato se convierte en uno de sus principales maestros de medicina. Zavalza, al igual

\footnotetext{
${ }^{54}$ Llamamiento que hace Francisco Madero para que el pueblo se levantara en armas contra el gobierno de Porfirio Díaz el 20 de noviembre a las seis de la tarde.
} 
que sus mentores anteriores, su padre y el doctor Cuenca, poseía un sentido de humanismo médico que lo llevaba a valorar tanto el poder curativo de "una larga conversación” o "las manos del médico sobre la cabeza del enfermo” como el de "unas cápsulas de opio” (225). Decide anteponer en base a su filosofía profesional el bienestar del paciente e incorporar la sabiduría de diversas tradiciones curativas a la novedad exclusivista de los discursos científicos. Su sobrio y antihegemónico informa su tolerancia a la hibridez dentro del campo médico, así como su aceptación de las condiciones sentimentales que le impone Emilia.

Los hombres que moldean el desenvolvimiento de Emilia en lo profesional y en lo sentimental son, con la excepción de Daniel, hombres que rompen con el patrón de masculinidad establecido, y que, una y otra vez, rechazan la tradición punitiva que recae sobre las mujeres cuando éstas ambicionan su propia realización, bajo sus propios términos. De otro modo, difícilmente podrían asumir y fomentar la controversial y aparentemente contradictoria individualidad de la heroína. En contraste con el mundo de buenos y malos en el cual opera Daniel, Zavalza viene a ser el reconocimiento del falso sentido de autoridad derivado de los juegos dicotómicos que permean las estructuras más poderosas de la sociedad. Zavalza es capaz de asumir los misterios de la medicina tal cual acepta la incertidumbre del amor dividido que le ofrece Emilia. El médico y el revolucionario presentan paradigmas opuestos de masculinidad. El primero es un individuo "liberal e indulgente respecto a los deseos autónomos de su colega y compañera sentimental”, mientras que el segundo, a pesar de su identidad revolucionaria, encarna los valores patriarcales que relegan a la mujer al espacio doméstico (Rivera Villegas 43). 
Lo que sería en el Bildungsroman femenino del siglo diecinueve motivo de suicidio, en Mal de amores adquiere un carácter de sosegada reflexión. Es innegable que la experiencia de querer a Zavalza “tanto como a Daniel” presenta, en principio, una sensación de ambigüedad con la que confiesa no saber "cómo lidiar” (385). No obstante, su educación bajo el modelo pedagógico de los Sauri-Veytia, la solidaridad masculina que recibe por parte de sus maestros de medicina, y la perspectiva que le proporcionan sus experiencias personales con las revueltas revolucionarias, le permiten sobrevivir y sobreponerse al conflicto sentimental. Zavalza, al final de la novela es descrito según la imagen que tenemos de Diego Sauri. Se le describe como antes Josefa Veytia había descrito a su marido. Como Diego, Zavalza era un "un hombre extraño entre los hombres, un hombre querible como ningún otro”, un hombre que, como su padre, le inspira tranquilidad en las arbitrarias situaciones históricas y sentimentales con las que tiene que lidiar. Emilia, en última instancia, favorece racionalmente el modelo de masculinidad que ve en su padre, aunque no consiga solucionar su dilema sentimental ${ }^{55}$.

En cuanto al asunto de la maternidad, Mastretta nuevamente opta por la representación subversiva de la supuesta experiencia cumbre de la mujer. En Mal de amores ya no solo se limita a abordar el tema desde la interioridad de la conciencia del personaje protagónico, sino que a nivel social "propone nuevas reglas en cuanto a las relaciones familiares, la maternidad y la paternidad” (Ela Molina 139). La experiencia maternal no adquiere el protagonismo que ostenta en Arráncame la vida. Se desconoce la

\footnotetext{
${ }^{55}$ Paralelamente en Arráncame la vida, Catalina manifiesta preferencia sentimental por Carlos Vives, quien asimismo se aproxima al modelo de masculinidad aprendido del padre de la protagonista.
} 
paternidad de los hijos de Emilia, aunque las dudas que expresa Daniel al observar los parecidos físicos y de carácter en los hijos de ésta sugiere que, en efecto, los hijos no son de Zavalza. Emilia rehúsa dar crédito a las indagaciones de Daniel y simplemente insiste en que "todos los hijos son de Zavalza” (412).

La subversión de los papeles tradicionales femeninos se centra en la problemática de la bigamia que caracteriza a la protagonista de Mastretta. La autora explica en una entrevista con Carlos Mateo Coria-Sánchez que su conducta "resulta subversiva porque no es habitual entre las mujeres” (169). Emilia, en resumidas cuentas, es un personaje difícil de encasillar en paradigmas convencionales de género. Fiel a su caracterización posmoderna, su conducta oscila entre lo contradictorio y lo ambiguo. Según Jane E. Lavery, Emilia "is a hybrid combination of [stereotypical] womanly traits -passivity, passion, warmth -and [traditionally thought of as] manly qualities such as intelligence and determination” (92). Según los parámetros de conducta aceptados en una sociedad patriarcal, la infidelidad, más que la inteligencia o la determinación suelen penalizarse en la mujer y tolerarse en el hombre. Dentro de las expectativas culturales latinoamericanas en particular, el hombre infiel o mujeriego no resulta realmente subversivo. La mujer infiel o polígama, en cambio, estremece los cimientos tradicionalistas de orden social y de la vida familiar.

Mastretta explica su crítica a la doble moral expuesta en Mal de amores durante la entrevista con Coria-Sánchez. La escritora explica que ha "visto algunas veces a los hombres enfrentar su amor por dos mujeres como una riqueza no como un drama” y que Emilia es una propuesta deliberadamente subversiva, ya que su actitud ante su amor por Daniel Cuenca y Antonio Zavalza concuerda con el estereotipo de comportamiento 
masculino. Según afirma la escritora, la actitud de Emilia "resulta subversiva porque no es habitual entre las mujeres... pero es una actitud común entre otros seres humanos, con los que Emilia comparte mil cosas [menos] el género” (169). Asegura que pretende depositar en Emilia la actitud de “desenfado” y “naturalidad” con la que algunos hombres mantienen relaciones sentimentales con más de una mujer, sin que dicha conducta acarree mayores consecuencias.

En 1986, Jean Franco afirmó que “estamos...en un período de crisis que ha visto el derrumbe de las $<<$ narrativas maestras $>>$-las teorías globales y totalizantes basadas siempre en la exclusión de lo heterogéneo” (42). Con Emilia Mastretta cuestiona la estructura social moderna, basada en gran medida en conceptos de progreso, perfeccionamiento y coherencia de la identidad individual. Mastretta propone que tales fundamentos sociales han perdido credibilidad y que la individualidad a la que aspiraba la modernidad no concuerda con los planteamientos ontológicos de la postmodernidad. Por tanto, ante la imposibilidad de llegar a la ansiada madurez y culminación coherente del período formativo, en lo que se refiere al modelo presentado en Mal de amores, permanece la pregunta -“¿Cuántas Emilias? La de Zavala, la de sus hijos,... la médica, la boticaria, la viajera, la suya” (413). 


\section{CAPÍTULO 4: TREINTA AÑOS (1999)}

\subsection{FORMACIÓN A PARTIR DE LA INVENCIÓN: MEMORIA, NOSTALGIA E IMAGINACIÓN}

En Treinta años se respira el mundo mítico de espejismos, repeticiones y fantasía con el cual Gabriel García Márquez deslumbró al público lector de Cien años de soledad en 1967. Treinta años después de su publicación la protagonista de Boullosa, Delmira Ulloa, se exila de Agustini, pueblo imaginario en el estado de Tabasco al cual no ha regresado desde su forzosa partida. La novela relata en primera persona el período de crecimiento de la protagonista entre las edades de ocho y catorce años. Delmira presenta su formación desde el espacio narrativo que logra reproducir, tres décadas más tarde (desde Alemania), a partir de la nostalgia por el país perdido. Una mezcla ambigua e inexacta de recuerdos e imaginación la lleva a regresar a una edad dorada repleta de magia y ensoñaciones de su Agustini querido.

Es evidente que la obra del maestro colombiano informa la escritura de Boullosa. A su salida de México, Delmira recibe un regalo de una pasajera que la acompañó y que escuchó su historia en el avión. El obsequio era Cien años de soledad -“es fantástico, tienes que leerlo; lo está leyendo el mundo entero” - le asegura la acompañante. Post Cien años, utilizar el vocablo años para titular una novela hispanoamericana hace sonar las alarmas de la parodia intertextual. Debido a una serie de paralelos estilísticos como lo son la estructura circular, la repetición cíclica, y la narración realista de sucesos inexplicables dentro de la lógica cientificista moderna, se evidencia el ejercicio paródico que Boullosa pone en práctica en Treinta años. El exilio de Delmira y, por ende, la narración parte precisamente del encuentro de la heroína de Boullosa con la célebre 
novela latinoamericana. De hecho, los treinta años a los que se refiere el título son las tres décadas de soledad de Delmira ${ }^{56}$; son sus treinta años de exilio, que coinciden exactamente con el número de años que han pasado desde aquel primer encuentro fortuito de la protagonista con el texto de García Márquez. Son las experiencias de la lectura y el exilio las que le permiten recurrir a la imaginación y a la rememoración. Así, hace el intento de sobreponerse al trauma producido por el distanciamiento físico de sus raíces míticas y lingüísticas.

El pretexto para entrar en el ejercicio del artificio literario de escribir sus memorias es la epidemia gripal que se apodera de sus facultades racionales y físicas. El desolador invierno alemán la hace contraer una fuerte gripe que le produce un estado de agotamiento generalizado, en el cual se justifica el carácter inestable del relato de Delmira. Lo que leemos es, confiesa la narradora: “la fantasía que elaboré para sostenerme contra el abominable invierno alemán” (16). Antes de avanzar en la lectura se pone en duda la veracidad de lo relatado. Se trata de una variante de la útil y conocida estrategia del narrador poco fiable que emplea Cervantes en El Quijote- el implantar la duda en el lector en cuanto a las facultades del narrador o del personaje protagónico. Llegada a su fin la estancia en Alemania, Delmira pasa a hacer un balance de su pasado, entablando una conversación consigo misma acerca de su experiencia formativa en México.

El exilio en Alemania, con todo, ha sido relativamente exitoso para Delmira, quien se desenvuelve como editora de textos de Lope de Vega para estudiantes alemanes

\footnotetext{
${ }^{56}$ Así lo sugiere Nancy Abraham Hall en su estudio "Delmira en el exilio: Los treinta años de soledad de Carmen Boullosa”.
} 
de español. Irónicamente, contempla volver a México debido a las desafortunadas circunstancias que ella misma ha provocado. Ha perdido su empleo, producto de un “error imbécil”, el alterar “pasajes de Lope por rebelión y fastidio”, habiéndose, de paso, metido en "el tenebroso territorio de la mentira" (257). Como poseída por una fuerza autodestructiva y subconsciente, Delmira parece desear la ruptura con el mundo racional y sensato de Alemania para poder plantearse la posibilidad del retorno, al menos en el espacio de la memoria, a sus orígenes formativos. Pareciera querer ocasionar su despido como medio de justificación para emprender el viaje a sus orígenes mexicanos y desertar del mundo lógico, moderno y predecible del corazón europeo.

Boullosa, con el pretexto de la enfermedad y la melancolía del exilio revela importantes paralelos entre el acto de recordar y la experiencia vital que tenemos con el pasado. Al recordar tenemos acceso a una realidad, ya sea histórica, personal o de otra índole, que se filtra y se personaliza según nuestra concepción del mundo, nuestra conveniencia y demás imperativos. La rememoración posibilita la construcción de un discurso propio donde se da respuesta a, o al menos se abordan, preguntas existenciales. En el desafío que supone la reconstrucción del pasado se vislumbra un reconocimiento de la porosidad de la frontera entre la realidad y la ficción, entre la experiencia tangible y el terreno de las emociones. Tales emociones adquieren singular protagonismo en este Bildungsroman de Boullosa, donde el valor de la historia personal de la protagonista se mide, fundamentalmente, según sus emociones, ansiedades y nostalgias con respecto al pasado y al acto de revivirlo.

Delmira Ulloa proviene de una de las familias fundadoras del pueblo, una familia adinerada, cuyo dominio económico en la región es aún visible. Además, posee un 
privilegiado estatus étnico; es de fisonomía europea (blanca o güera) en una población altamente mestiza. Como en Antes, predomina la descendencia matrilínea y la historia se centra en los vínculos conflictivos que existen entre Delmira, su madre y su abuela. En la residencia de las Ulloa viven exclusivamente mujeres, salvo por las cortas y espaciadas visitas del tío Gustavo, que tanto entusiasman a la niña. A la percepción infantil de Delmira los lazos familiares entre su descendencia matriarcal son tan misteriosos como problemáticos. A pesar de que la figura de la abuela desempeña un rol fundamental en la formación de su cosmovisión, el desprecio y negligencia que padece por parte de su cuidadora principal le dejan fuertes secuelas emocionales. La abuela, quien debiera ejercer un rol de sabia protectora, en realidad reafirma el ambiente de soledad y exclusión en el que se desenvuelve Delmira. "Yo era como una niña llegada a esa casa por error”, recuerda Delmira, aludiendo a la sensación de orfandad que sufre en su entorno doméstico (19).

La representación de la orfandad y la experiencia problemática del niño con su madre (o abuela) son temas predominantes en la narrativa boullosiana ${ }^{57}$. La presencia de la figura maternal en Treinta años refuerza la ausencia de ésta ya que el contacto tanto emocional como físico es escasísimo; y las demostraciones afectivas entre ambas son prácticamente nulas. Delmira se la pasa admirando a su madre como si ésta fuese una diosa exhibicionista e intocable. La rememoración de la figura materna se centra fundamentalmente en las descripciones eróticas del cuerpo y la sexualidad de la madre:

\footnotetext{
${ }^{57}$ La representación de la orfandad y las relaciones problemáticas entre madres e hijas posee una base autobiográfica ya que la madre de Boullosa fallece cuando la escritora tiene catorce años.
} 
A ella pude verle también, no sólo sus largos cabellos sueltos, también con todo detalle la ligera prenda que vestía, como si la estuviera tocando, un largo camisón de fino lino que agitaba la corriente de aire, marcándole el cuerpo como una segunda piel meneada con ligeros ataques de risa... Mamá era todo redondeces, como lo soy ahora yo... alzó con su mano izquierda el camisón. El cielo se tiño de rojo encendido, iluminando de una manera más cálida el caer del día, y yo sentí, inspirada por la tonalidad del atardecer, cómo mamá vació con la mano derecha la jícara de agua sobre el negro triángulo de su sexo... El agua parecía caer lentísima. Mamá se encorvaba y echaba la cabeza atrás, alternativamente, con la gracia de una bailarina. Estaba pegada al balcón y no parecía preocuparle que la vieran desde la calle en una actividad tan vergonzosamente íntima. (24)

De acuerdo con las teorías del psicoanálisis, el desarrollo de las hembras va estrechamente ligado a la alianza que se forja entre madre e hija así como la resolución del complejo de Edipo femenino en el cual la hija subconscientemente desea sostener relaciones sexuales con el progenitor del sexo opuesto para cancelar el predominio del padre. En el caso de la protagonista de Boullosa, las figuras maternales impiden el desarrollo de ataduras emocionales saludables entre las mujeres. Nancy Chodorow explica que "in a society where mothers provide nearly exclusive care and certainly the most meaningful relationship to the infant, the infant develops its sense of self mainly in relation to her” (78). Para la protagonista de Treinta años, esta relación de apego con la madre ha sido negada, por lo que el vínculo con ésta se convierte en una quimera, además 
de una mutilación psicológica. Para Delmira la comunidad femenina a la que puede acceder es radicalmente hostil y excluyente. El resultado es que le es prácticamente imposible desarrollar un sentido de solidaridad y complicidad con el género femenino. Como mecanismo defensivo, ésta se refugia de su ansiedad en las fantasías de la mente infantil, que para ella se convierten en un tormentoso mundo interior de fobias, misterios y fantasmas.

El psicoanálisis se convirtió en uno de los más influyentes metarrelatos explicativos del desarrollo psíquico humano. Y, como es de esperar, se ha utilizado ampliamente en la crítica literaria para explicar y sugerir las motivaciones “subconscientes” de la dinámica de un texto y sus personajes. No obstante, los detractores del psicoanálisis cuestionan la legitimidad y el punto de vista hegemónico, masculino, en los cuales está enraizada la teoría freudiana. Las teorías psicoanalíticas tienden a acercarse a la concepción del sujeto femenino desde una postura patriarcal y marginante. Como reitera Hirsch en The Mother/Daughter Plot, "for psychoanalysis, and in a large part for psychoanalytic feminism, a continued allegiance to the mother appears as regressive and potentially lethal...Maturity can be reached only through an alignment with the paternal, by means of an angry and hostile break from the mother” (168). Es otras palabras, la mujer es concebida y castigada de acuerdo con su desempeño como madre, el rol primordial que le asignan los discursos legitimadores de las estructuras del patriarcado.

La figura de la madre no es fácilmente clasificable; tiende a encerrar un carácter ambiguo y problemático según las expectativas sociales de la experiencia maternal. Marianne Hirsch explica que la teoría de Julia Kristeva ilumina el debate en cuanto al 
sujeto femenino en su faceta de madre. Para Kristeva la madre se entiende "as split subject, as locus of the semiotic, as both phallic and castrated, present and absent, omnipotent and powerless, the body before language, unrepresentable, inexpressible, unsettling, [and] has become the privileged metaphor for a subversive femininity” (Hirsch 171). En Treinta años la expectativa psicoanalítica del proceso formativo no funciona. Ni la figura maternal ni Delmira se subscriben a la lógica de progresión que suponen las teorías del psicoanálisis.

El contexto literario posmoderno en el que escribe Boullosa le permite subvertir la teoría del psicoanálisis de Freud, que ya para la década de 1970 se veía como un modelo que en realidad impulsa la subyugación femenina ${ }^{58}$. Boullosa se vale de la inocencia infantil de Delmira y la protagonista de Antes para abogar por un proceso formativo posmoderno, es decir, conflictivo, inconcluso y ambiguo, mas no marcado por los resentimientos subconscientes que se deslindan de las teorías del psicoanálisis. Boullosa además, se desasocia de la lógica que rige al psicoanálisis. La protagonista no alcanza una conciencia de sí misma al separarse o distinguirse de la figura materna ${ }^{59}$. De hecho, la rememoración de Delmira, en su totalidad, se centra en la descripción de la experiencia de orfandad y marginación, con lo cual se le permite al lector sacar sus propias

${ }^{58}$ De acuerdo con Hirsch en The Mother/Daughter Plot, una variedad de escritoras erróneamente "follow Freud in blaming the mother for the daughter's victimization and make mother-hate the condition of female liberation and self-determination” (131).

${ }^{59}$ Patricia Waugh explica la idea de la identidad o conciencia de sí que se deriva del distanciamiento con el cuidador: "in most psychoanalytic theories, selfhood is achieved predominantly by separation. The dependent infant is regarded as having achieved autonomous subjectivity when, regarding the primary caretaker...as simply an object against which it defines its subjectivity, an instrument of its needs, it becomes a self by breaking free of her and asserting its own separateness, its difference, its boundaries (21). 
conclusiones acerca del estado psicológico de la protagonista en su etapa adulta. La protagonista, en última instancia, no demuestra "odio" subconsciente o resentimiento hacia las figuras maternas que le negaron del afecto esencial para su desarrollo.

Algunos críticos proponen que el período formativo de Delmira es un proceso progresivo en el cual la protagonista "develops emotionally as well as physically and intellectually, and by the end of the flashback portion of the narration, achieves a mature level of self and social awareness” (Stephanie Leigh Vague 112). No obstante, en realidad el desenvolvimiento formativo de Delmira subvierte las nociones de madurez gradual que asociamos con el Bildungsroman tradicional. Su desarrollo tanto emocional como intelectual es sumamente problemático desde la infancia hasta la etapa adulta a partir de la cual escribe. Delmira revive e inventa su pasado precisamente para lidiar con su conflictiva identidad adulta. Al escribir reconoce el artificio de la rememoración como mecanismo de supervivencia existencial. Recordemos que es desde la supuesta madurez adulta desde la cual admite que, de no ser por el recorrido facilitado por la ficción, “no hay donde volver", puesto que al rememorar y reinventar su infancia ha "vuelto al único sitio que quedaba: al recuerdo" (259). Por tanto, su relación con su identidad y la concepción de su propio proceso de maduración sugiere un conflicto que queda irresuleto y que en el fondo cuestiona, como lo hacen las protagonistas de las novelas estudiadas hasta aquí, la legitimidad del concepto progresivo de maduración.

La rememoración y el acto derivado de rellenar y alterar espacios de un tiempo pasado funcionan en Treinta años de manera particular. Primeramente, el período formativo de Delmira desestabiliza la idea misma de la formación según el modelo eurocéntrico. Adquiere singular importancia la mitología local, indígena y mestiza de 
México, y por extensión de Hispanoamérica. El proceso de Bildung aquí es profundamente híbrido; no reproduce ni privilegia los discursos formativos importados a la América hispánica a través de todo un género literario originario de Europa y que respondía a un proyecto sociológico y pedagógico característicos de la modernidad europea. Por tanto, los años formativos de Delmira se ven imbuidos de la herencia y tradiciones precolombinas así como por la fe en determinados valores y tradiciones traídos del viejo mundo.

De pequeña, Delmira admite que se siente como pez fuera del agua en todos los espacios físicos que ocupa, como lo son su domicilio y la escuela a un nivel concreto así como el espacio mítico y cultural del pueblo rural, el cual le provee, en un sentido más abstracto, cierta coherencia existencial. Parece tener conciencia de la arbitrariedad y provisionalidad de sus circunstancias domésticas de manera que el mundo fantástico de Agustini le proporciona cierto sentido a su vida. En su casa, no solo carece de cariño maternal por parte de la madre y de la abuela sino que además es excluida cruel y sistemáticamente de todo círculo afectivo, al cual normalmente debía tener acceso. Quizás el mejor ejemplo de tal exclusión ocurre cuando Delmira erróneamente cree que su madre esconde a un hombre en su habitación y, convencida, se lo informa a la abuela. Al enterarse la abuela le proporciona una golpiza a su hija, y, una vez enterada del error de la niña, comienza a besar y a abrazar a su hija pidiendo disculpas:

La abuela me miró entonces con ira. Tal vez era la primera vez en toda mi vida que me clavaba la mirada.

- ¡Pilguaneja! -me gritó, con todo lo que le daban sus pulmones. ¡Te rompería la crisma! ¡Pero en ti no gastaré jamás ni una sola de mis pocas 
fuerzas! ¿Oíste? ¡Pedazo de persona! ¡Parida en mala hora! ¡Túuu! Gritó esta última sílaba señalándome, alargando la “u” como para aventármela, pero tras el "tú” no dijo nada más. Le bastó con el pronombre para infamarme de manera radical. (26)

Así, una y otra vez Delmira hace frente, como puede, al trauma de la marginación familiar que padece. A pesar de ello, la Delmira adulta no guarda rencor a sus modelos disfuncionales de maternidad. Por el contrario, el tiempo y la distancia la hacen extrañar los cuentos de la abuela, de los cuales se vale para organizar el relato. Asimismo, en el colegio se acentúa su existencia solitaria y reconoce que le es imposible acercarse a las demás estudiantes. A la pregunta del profesor de secundaria - “¿Tienes amigas en la escuela?” Delmira contesta: “¿Dé dónde las saco? Las de mi salón tienen la cabeza llena de paja, no hay ni una sola humana, ni unita... nomás hablan de casarse, de novios, de cómo va a ser su casa” (151). Ante el panorama desolador en lo doméstico y en lo público en el que se ve obligada a subsistir, el ejercicio de la rememoración le sirve para hacer frente a la tagedia existencial de sus años formativos en Agustini.

La estructura de Treinta años coincide con las etapas de trauma y falta de control en la vida de Delmira. Se trata de una estructura fragmentada, como también lo son las memorias de la protagonista. Tal y como propone el estudio de Nancy Abraham Hall, la protagonista "experimenta... un tipo de muerte distinto en cada una de las secciones de la novela: la muerte de la inocencia a la edad de ocho años cuando presencia una escena de sexo, la muerte de la niñez a los doce años cuando menstrúa por primera vez, y muerte de país cuando a los catorce años tiene que exilarse” (186). Cada uno de los acontecimientos cruciales genera sentimientos de vergüenza y vulnerabilidad, los cuales, a su vez, 
producen el extrañamiento con que Delmira se ve a sí misma y al entorno que la rodea. Las tres manifestaciones de trauma, en suma, ponen fin a la inocencia infantil y obligan a la protagonista a entrar prematuramente al desamparo del mundo adulto.

La primera “muerte” o evento traumático en la formación de Delmira ocurre al presenciar a su madre sosteniendo relaciones sexuales con el sacerdote del pueblo en 1961, año en que comienza el primero de los tres períodos formativos que dan orden cronológico al texto. Treinta años después dicho suceso es uno de sus más vívidos recuerdos de trauma y que, en su momento, intenta suprimir. La Delmira adulta confiesa que aunque lo que hacían no fuese pecado "[se] sentía desesperada. Lo que hacían rompía algo en [ella], destrozaba, [la] despojaba... eran la encarnación del propio mal” (41). Por una parte, rompe con la inocencia infantil, inconsciente de la sexualidad adulta y, por otro, expone el engaño del líder religioso en un mundo estructurado moralmente en base a las normas de conducta católicas.

La segunda “muerte” ocurre en 1965 cuando Delmira experimenta su primera menstruación. Como en Antes, el sangramiento o, a los ojos de Delmira, el desangramiento, produce una sensación de terror en la protagonista, al punto de no sobrevivirla en la primera de ambas novelas. En la mitología boullosiana el fenómeno de menstruar es sinónimo de la muerte y del terror existencial. En Treinta años la pérdida de la inocencia infantil adquiere un carácter simbólico, asociado a la invasión del cuerpo y la identidad de la niña. La narración de la menarquia se presenta en el pasaje que relata un inofensivo chapuzón en el río un caluroso día de verano. Los cambios fisiológicos son vistos aquí como una penetración simbólica que viola la inocencia infantil. Con el 
característico estilo poético de Boullosa ${ }^{60}$, tan dado a la evasión de descripciones realistas (sobre todo si se trata de eventos de trascendencia existencial en la narrativa), la narradora relata el suceso:

En un segundo, sentí el dolor atroz en la vulva, donde el filo de una piedra se había clavado, sentí el rebote de golpe en la cintura y en el vientre, y vi alzado frente a mis ojos, corriendo impávido, al río, un solo cuerpo sin gotear siquiera, cabalgando rápido, sólido, un solo músculo tenso sobre mis ojos, uno súbitamente azul y lleno de luz que me había abandonado despojándome de mi propia fuerza, desmusculándome (si se puede decir así), hiriéndome, desnudándome (125)

La entrada al río es, asimismo, alegórica del sacramento del bautismo. Entra al río con cuerpo de niña y, al salir, se ha transformado, para su desagrado, en adolecente. La temida etapa de transición entre la infancia y la adultez se tiñe literalmente de sangre, sangre que Delmira entiende como la evidencia de una terrible agresión física y emocional.

En el capítulo titulado “Creciendo”, igualmente perteneciente a la etapa que comienza en 1965 Delmira describe las trasformaciones físicas que sufre en la pubertad. “En un santiamén se llenó de extrañezas mi cuerpo”, recuenta el trauma que le produce observar los detestados cambios en su cuerpo. Nancy Abraham Hall explica que Boullosa "suele recurrir a los fluidos corporales, como meados, vómito, diarrea, flema y flujo

${ }^{60}$ Carmen Boullosa explica en la entrevista que concedió a Erna Pfeiffer que "para que un libro funcione, mientras más mentiras cuentes, más verosímil es. Si tú te apegas a la realidad, es muy poco probable que funcione como libro literariamente emocionante” (28). 
menstrual para dar a entender la falta de control de un personaje en momentos precisos o sobre su vida en general” (188). Delmira reacciona con una indisposición estomacal al percibir por primera vez la transformación corporal:

...tardé en saber que yo tenía pechos de mujer, cobré conciencia de ellos hasta que un día no pude cerrarme una blusa del uniforme escolar... Era una blusa vieja...No me cerró, y al tirar y tirar la tela vi en mí esas dos protuberancias. Me sentí tan mal de tenerlas que no quise ir a la escuela, y en defensa propia me solté del estómago. No volví a pensarlas en todo el día porque lo pasé yendo y viniendo al baño, con un chorrillo distractor que me llenó todos los momentos y que no provenía sino de mi asombro y mi furia. Me dio diarrea de enojo. (142)

A la edad de catorce años, Delmira enfrenta el tercer evento traumático que afecta su formación de manera definitiva. Esta etapa coincide con su toma de conciencia social y política. Comienza a interesarse por la causa de los trabajadores sindicalistas, quienes luchaban en contra del gobierno de Villahermosa por sus derechos. Delmira se involucra en una manifestación organizada por el cura en protesta por el asesinato del Pelón, activista político del pueblo, y termina siendo arrestada por las autoridades militares del estado. Con orgullo y valentía publica el panfleto que sería su primer escrito impreso. "Había hecho cientos de copias de mi panfleto, al final del cual había escrito una firma: “Delmira la de Agustini”. Mi primera publicación...” afirma la joven activista revelando su admiración y juego intertextual con relación a la poeta uruguaya Delmira Agustini.

Este tercer fragmento formativo sella la trayectoria de marginación que se inicia con su indeseado nacimiento. Si en principio es expulsada como un desecho cualquiera 
del cuerpo de su madre para entrar a una infancia marcada por el abandono y la marginación, ahora le corresponde hacer frente a la expulsión simbólica y literal de su centro cultural para pasar a formar parte del también anulador fenómeno del exilio. Su participación en la manifestación debe entenderse como un desafío a su propia familia y su privilegio socioeconómico. Es una renuncia ideológica a la corrupción gubernamental que avalan los privilegios de las clases pudientes en la escalera social, a las cual sin quererlo pertenece. Asume, pues, la obligatoria orfandad social con la que se castiga al disidente.

Cuando vienen por ella para llevársela presa, Delmira rememora: “Sentí que me orinaba, pero no me estaba haciendo pipí... ¿Era pavor, pánico?” (235). Los oficiales venían para llevarla a la cárcel; no obstante Delmira, en este instante, sufre una última demostración de desafecto maternal. Al enterarse de la intención de los policías, la abuela se interpone diciendo -“si se la llevan, llévenme con ella también”. La madre de Delmira, parece no inmutarse por la suerte de su hija y reacciona con pánico solo por el posible encarcelamiento de la abuela -“Tú no, mamá -chilló mamá, sujetándola de la falda, como si ella fuera la niña -tú no... -con los ojos anegados de lágrimas que no voltearon ni un instante a verme” (235). Al final, el tío Gustavo consigue una carta de protección del gobernador, quien ordena -“Es mía Delmira”, con lo que logra escapar de la cárcel y del país definitivamente. "No volví a ver la casa de la abuela. No la he vuelto a ver. Nunca volví a ver a mamá”, dolorosamente recuerda Delmira a sus cuarenta y cuatro años (249).

De no haber sido por su apellido, Delmira hubiese permanecido en la cárcel y muy probablemente hubiera sido torturada o asesinada, como es costumbre de los militares sanguinarios que la han tomado prisionera. Sin embargo, aun así padece 
humillaciones terribles. Los soldados eran forasteros, como simbólicamente lo era ella ahora en su propio pueblo -“de haber sido de Agustini no se habrían atrevido a alzarle un dedo a la hija y nieta de los Ulloa.” (236). En esta ocasión el pueblo, como entidad colectiva, le falla ${ }^{61}$. Todos la ven desfilar por las calles mientras los oficiales la llevaban prisionera y nadie, salvo el médico del pueblo, es capaz de salir en su defensa. "Agustini no alzaba la voz por mí”, cuenta Delmira rememorando el desamparo, esta vez público, que le demuestran los miembros de la comunidad ${ }^{62}$. (235). A la petición de un reportero de un diario local que le pertenecía al gobernador, los soldados “posan” para la foto haciendo alarde de las vejaciones a las que sometían a Delmira:

Para la segunda [foto], me alzaron la falda.

Para la tercera, uno me abrazó groseramente.

Para la cuarta, me hicieron hincarme, poner la cara al piso, y uno de ellos puso su enorme bota sobre mi espalda. (239)

La deshumanización de la niña se ratifica a un nivel social, estatal. Así como padece el aislamiento emocional en casa y en el colegio; ahora los espacios oficiales del poder político le dan la espalda por su supuesta transgresión cívica.

Con respecto a la separación física entre Delmira y su madre hay que resaltar que Delmira no le guarda rencor, aunque Boullosa le depara un desenlace punitivo en un

61 Teniendo en cuenta el juego intertextual de Boullosa con la obra de Márquez, este episodio nos remite a la inacción y, por ende, culpabilidad del pueblo testigo en Crónica de una muerte anunciada.

${ }^{62}$ En parte por el miedo a la represalia policíaca y en parte porque ella representa, por herencia familiar, a la burguesía abusiva y apática. 
intento de hacer justicia poética. Como quien salda una larga deuda moral, la madre de Delmira sufre una muerte espantosa. Boullosa hace uso de descripciones de corte naturalista para relatar su padecimiento:

Primero una mancha negra le apareció en la espalda...una mancha como si un puño le hubiera golpeado... Después le comenzaron las molestias en el brazo izquierdo, a la altura de la axila. Ahí se le abrió una llaga que le comenzó a crecer y a crecer. Se le infectó, y por más que le echaban polvos de sulfas... no cedía. Se acostaba en una cama de azúcar que le hizo construir la abuela, un cajón de madera del tamaño de una cama que en lugar de tener colchón tenía varios kilos de azúcar, rodeada por un canalito de agua para impedir la subida de las hormigas. (249)

La madre finalmente fallece, según el parte médico, de un infarto cardiaco. No obstante, Delmira conjetura que se “murió del corazón, pero de otra forma. Se le pudrió de afuera para adentro”, según la hija, porque el sacerdote había dejado el pueblo, por lo que la verdadera causa de la muerte se le atribuye a "la ausencia de amor" (250). En última instancia, Delmira hace lo que puede por explicarse un dolor inexplicable, el de no haber experimentado jamás el afecto maternal, agravado por la constante y apática presencia de la madre en la vida de la niña. Rehúsa dar crédito a la idea de que su madre haya muerto de una enfermedad en concreto, ni tampoco, metafóricamente, por la ausencia de la hija exilada. La muerte de la madre, en la lógica de la protagonista, la ocasiona únicamente la falta de amor romántico.

Es pertinente añadir un cuarto incidente aterrador y definitorio a los tres que reconoce Nancy Abraham Hall en su estudio (186). Se trata del intento de violación que 
tiene lugar en la panadería y que coincide con los sucesos en torno al año 1965. Muy poco después de los trastornos ocasionados por la pubertad, Delmira es secuestrada por el panadero del pueblo mientras regresa del colegio un día de lluvias torrenciales:

Una mano gorda sobre mi boca me impedía gritar. No entendí que ocurría. Sólo recuerdo el sótano de la panadería, un jaloneo absurdo, las manos del hombre esculcando mis ropas, mis gritos, ahora que ocupaba en otra cosa sus manos, los pies resbalando en piso mojado, el golpe de su cuerpo al caer sobre la mesa de harina, y que de pronto entró el profesor de la secundaria... gritándole... ¡Alto ahí! (149)

Una vez más, es una figura masculina la que rescata a Delmira en circunstancias aterradoras. Según Abraham Hall, "tras cada trauma, alguien relacionado con libros le ayuda a ganar un sentido de armonía y a pensar más allá de Agustini” (186). Se cumple aquí el estereotipo de que el mundo del conocimiento impreso es del dominio masculino. Delmira, aunque instruida desde la cuna en la tradición oral que le imparte la abuela, muestra preferencia por los mundos que descubre en los textos que le facilitan las figuras masculinas de su vida.

En conjunto, las experiencias perturbadoras que sufre Delmira determinan su inhabilidad de construirse una identidad personal coherente que la conduzca a una etapa de certeza y madurez adultas. Las propuestas posmodernas de Boullosa aquí desarticulan el proyecto utópico de formación tal y como se ve en Europa durante el siglo diecinueve. Cada uno de los episodios, o muertes, como les llama Abraham Hall, imposibilita el proceso formativo, tanto a nivel individual como social. Como se ha expuesto, no son solamente los vínculos traumatizantes con sus seres más allegados los que impiden el 
bildung de Delmira. De acuerdo a su experiencia el entramado social, machista, violento, corrupto, también se congenia con el desafecto familiar para desarticular las expectativas modernas de formación personal.

\subsection{DESARTICULANDO EL MUNDO “FIEL A LAS LEYES DE LA FÍSICA”}

La ficción mágico-realista, como herramienta comunicativa del mundo premoderno que conforma la cosmovisión tabasqueña de Delmira, impregna en Treinta años toda la narración del proceso formativo. El terreno rural, alejado de las ciudades capitales, más cercano a los mitos ancestrales de las culturas indígenas, hace posible el juego paródico boullosiano con los elementos mágico-realistas. Vale aclarar que la valoración de su propia realidad no es para nada mágico-realista a la percepción de Delmira; los supuestos sucesos extraordinarios le son naturales a ella y a los habitantes de Agustini. La rememoración del pueblo ficcional funciona en cierta medida como homenaje a García Márquez. No obstante, la obra de Boullosa aquí no supone una simple y transparente admiración de la obra cumbre del escritor colombiano. Agrega tensión paródica al poner en boca de Delmira la supuesta “desilusión al caminar por sus páginas”, quien a su vez intenta convencernos de que resistirá la tentación de imitar la disposición de Márquez al crear su propio territorio ficcional (255). En cambio, el espacio inventado por Boullosa refunde y rinde homenaje, con voz propia, al modo de contar historias inmortalizado por su maestro.

La parodia intertextual es una de las características más reconocibles del texto posmoderno. Para afrontar el peso de una tradición establecida, el artista posmoderno recurre a la parodia con el objetivo de descentralizar su hegemónico valor cultural. Linda 
Hutcheon explica en The Politics of Postmodernism que la conciencia posmoderna se enfrenta con la paradoja de que, "on the one hand, there is a sense that we can never get out from under the weight of a long tradition of visual and narrative representations and, on the other hand, we also seem to be losing faith in both the inexhaustibility and the power of those existing representations” (26). Sin darle la espalda al código narrativo de García Márquez, el ejercicio paródico le permite a Boullosa subvertir un discurso artístico desde dentro, apropiándose de su técnica expresiva, y así desarticular su autoridad. La propia autora ha expresado su sentir al respecto -“todos los escritores nos dedicamos por un lado a romper con lo que es, con lo que estaba atrás, y por el otro nos dedicamos a homenajear eso que estaba atrás y nos nutrimos así” (Ellen Spielmann 264). En Treinta años, Boullosa se apropia del lenguaje que empleó García Márquez para dar vida al mundo de hombres de Cien años de Soledad, ahora con el propósito de plasmar las fragmentadas memorias de orfandad y marginación de Delmira.

$\mathrm{Al}$ igual que en Macondo, en Agustini lo mágico se torna cotidiano. Como suele suceder en los textos que hacen uso de este estilo narrativo, la intervención de lo mágico ocurre de manera inesperada, poco comprendida y, con frecuencia, importuna los planes ordinarios de los afectados. Un domingo ${ }^{63}$ cualquiera, rememora Delmira, "todos los pájaros, sin importar el modo natural en que volaran... se dirigieron en picada hacia abajo, hasta tocar tierra, tras lo cual ninguno fue capaz de remontar el vuelo” (55). La magia del suceso pasa, sin trámite, de lo insólito a lo carnavalesco y, finalmente, a la transfiguración de lo fantástico a lo más ordinario y terrestre. La caída de los pájaros se

${ }^{63}$ Según Anna Reid, Boullosa “aprovecha la largueza de los ciclos provincianos” y utiliza la simbología religiosa asociada a este día para medir el tiempo en el pueblo (176). 
convierte primero en una fiesta: "Muchos niños pasaron el mejor de sus días. Gritaban más que los pájaros... como si la caída les hubiera traído la fiesta más divertida, una feria de picos y de sangre que los excitaba hasta la exasperación” (59). Para evitar enfermedades producto de la plaga de pájaros muertos, se respetó la opinión del médico y se incineraron en una hoguera que la narradora compara con las macabras hogueras de la Inquisición.

Otra dimensión crítica en cuanto al uso de lo mágico-realista en Boullosa tiene que ver con el fundamento que está detrás de ciertos pasajes. La escritora presenta, desde la perspectiva inocente de la Delmira niña, una fuerte crítica a la violación de la tierra y la naturaleza, de cuyos frutos viven los habitantes indígenas. La caída de los pájaros no es un simple hecho extraordinario contado con la aceptación más realista. Es también una protesta al maltrato de la tierra y la destrucción de los ecosistemas de la región. Estos “desastres ecológicos provocados por los hombres” además incluyen "una lluvia de ranas, un temblor, el estallido del volcán, un cambio de dirección de las aguas y una nube blanca [que] pasa por el pueblo acabando con los cafetales alrededor de él y provocando malestar [en] las personas” (Grazyna Walczak 153). La novela expone así las tensiones entre los blancos y los indios, entre los intereses de los líderes del gobierno y los de los más pobres del pueblo. Por tanto, conviene tener en cuenta la incorporación de elementos del realismo social a la hora de leer e interpretar los pasajes mágico-realistas en el texto. Sin embargo, no todo el realismo mágico boullosiano está anclado en la crítica social; hay otros momentos en que el estilo se eleva a un nivel poético, más afín a la primera incursión de Boullosa en la escritura literaria. 
La muerte de la sirvienta, un pasaje profundamente arraigado en la sensibilidad poética de Boullosa, se ve impregnada de material sobrenatural que se puede denominar mágico-realista. Delmira recuerda que la vieja Luz, amaneció uno de los tantos acontecidos domingos con "las llagas de Cristo” y que ya para cuando llegó el cura “levitaba con todo y silla de palo” (85). La anciana siente ganas de orinar y se dirige al baño ayudada por la nana Dulce. Alarmada por la tardanza de la señora en el baño, la nana “forzó la puerta del diminuto cubo sin ventanas [y] se encontró con que Luz no estaba. Al pie del excusado, descansaba la ropa de la viejita, los zapatos, la larga falda gris, la blusa, el fondo, los calzoncillos, las marcas de sangre que habían dejado sus ensopados zapatos... La negra Luz se había disuelto en orina” (86). El elemento mágicorealista funciona aquí debido a la representación de la imagen de la mujer negra en un territorio mayoritariamente mestizo e indígena. Como ha explicado Erik Camayd-Freixas, "el arte mágico-realista debe apoyarse en un escenario idóneo, en una realidad que lo justifique poéticamente. En Latinoamérica ese escenario es la 'zona afroindia' ” (292). Es decir, para que el realismo mágico se acepte como verosímil es imperativo que se situé en el escenario no citadino, donde la fe y la tradición autóctona justifican la aceptación del fenómeno extraordinario. Ese es precisamente el escenario de los cuentos de la abuela, los hilos conductores de esa fe, que en el fondo, es una especie de amuleto protector ante el realismo transparente y deshumanizante de la modernidad que ahora vive Delmira en el exilio.

Los ciclos de la naturaleza, la repetición de la muerte y el resurgimiento de la vida imbuyen a Macondo y a Agustini de una magia ancestral que sobrevive la temporalidad de un ciclo de vida y da sentido a los habitantes del pueblo. La circularidad de la 
tradición oral refleja el funcionamiento, también circular, de la acción de recordar, en la que retejemos una y otra vez las historias del pasado. Los cuentos de la abuela dan al texto de Boullosa un carácter cíclico y mítico, a través de los cuales Delmira selecciona y ordena las memorias que va a contar. Estas historias la hacen conocer el lenguaje del mito y, a su vez, la hacen ambicionar otros mundos más allá de la localidad donde opera y es válido dicho lenguaje. La memoria, en efecto, aloja también a los fantasmas; es un espacio íntimo donde rondan los recuerdos de seres y escenarios del pasado. Los juegos de la memoria de Delmira la hacen reconocer la dualidad y la circularidad del territorio de recuerdos que intenta reproducir. Estos son al mismo tiempo aterradores y encantadores, accesibles e invisibles.

El realismo mágico y la posmodernidad guardan una relación polémica. Dado que el realismo mágico se origina y se nutre de la modernidad, su transposición a textos propiamente posmodernos tiende a ser problemática. Como ha observado CamaydFreixas, el realismo mágico tiene puntos en común y también divergencias con la posmodernidad. Por una parte comparte una serie de elementos característicos de la literatura posmoderna como lo son la autorreflexión, la intertextualidad y la parodia, mientras que, por otra parte, difiere radicalmente en el "afán de totalización” que caracteriza, por ejemplo, a Cien años de soledad (295). En cuanto al uso del punto de vista mágico-realista en Treinta años, es útil destacar tanto su valor paródico como sus postulados posmodernos. Es quizás en tal hibridez estilística y filosófica en donde mejor quedan expuestas las características posmodernas del texto. Hay espacio tanto para la continuidad de los legados de la modernidad como para la postura revisionista y contestataria del periodo posmoderno. 
Siguiendo con la temática de la intertextualidad, en los estudios de Treinta años poco se ha tratado otro aspecto paródico e historiográfico de importancia. Se trata de los bautizos en masa que efectúa el cura del pueblo a una comunidad de indios damnificada por un temblor de tierra. El suceso evoca los bautizos masivos del freile franciscano del siglo XVI, Toribio de Benavente Motolinía, en los que una multitud de indígenas eran, sin ellos bien entenderlo, evangelizados según estipulaba el sistema de encomiendas instituido por la corona española. De no ser por el registro histórico al respecto, el pasaje parecería una exageración más de las tantas que tienen lugar en Agustini. En las labores de auxilio, el sacerdote del pueblo aprovecha para preguntar a los indios si habían recibido la fe del bautismo, “y a los que contestaban que aún no, los fue sentando en una banca que había hecho traer de la iglesia. Cuando la banca estuvo llena, hizo traer otra, cuando la otra se llenó hizo traer otra...” (66). Este encuentro con los indios, quienes, por cierto, son detestados por la familia aristocrática de Delmira, despierta en ésta el interés humanitario que luego le desarrolla el profesor de secundaria, convirtiéndola finalmente en activista y defensora de los habitantes indígenas del pueblo.

La nostalgia por el universo mágico que muestra Delmira, después de haber pasado treinta años de exilio en el "mundo fiel a las leyes de la física”, pone al descubierto la inconformidad existencial, posmoderna, con los valores más exitosos del mundo occidental. En gran medida, esa intranquilidad posmoderna, tan propia también del género Bildungsroman, desestabiliza los discursos hegemónicos que tienden a abogar por la estabilidad y privilegios de los organismos de poder. La propuesta boullosiana al reciclar y representar el espacio mítico que fecunda al realismo mágico apunta a la desarticulación de la tabla de valores de la modernidad. Sugiere además que ese "mundo 
fiel a las leyes de la física” también exige un acto de fe, como bien lo explicó John B. Bury al proponer que la fe en el progreso no era más que una etiqueta, optimista y dogmática, de inevitables procesos de cambio:

But if we accept the reasonings on which the dogma of Progress is based, must we not carry them to their full conclusion? In escaping from the illusion of finality, is it legitimate to exempt that dogma itself? Must not it, too, submit to its own negation of finality? Will not that process of change, for which Progress is the optimistic name, compel "Progress" too to fall from the commanding position in which it is now, with apparent security, enthroned?... A day will come, in the revolution of centuries, when a new idea will usurp its place as the directing idea of humanity. (229-31)

Mientras tanto Delmira escribe:

Hace tres décadas que no duermo en hamacas, que no veo a los objetos flotar, ni se aparecen al salir de mi cuarto un cocodrilo albino, un ejército de indias amamantando sabandijas, una legión de sapos estrellándose en mi balcón... Tengo seis veces cinco años sin oír por las noches el cuento de la abuela. Vine buscando un mundo fiel a las leyes de la física, está aquí rodeándome, aunque no pueda decir que lo tengo (253).

Así admite que los discursos magisteriales de progreso, razonamiento científico y universalidad que relegan al terreno de la fantasía un universo que para ella es "real” tampoco proveen las respuestas que prometen. 
Hay un segundo aspecto en el texto que también rompe con la convención de género de la novela de formación. Se trata de la representación de una orientación sexual “problemática”. Dentro de la tradición del Bildungsroman, la subversión de la orientación sexual convencional, es decir, de la heterosexualidad, es prácticamente inexistente. En Treinta años, en cambio, tenemos una serie de pistas que apuntan a la formación de una protagonista de tendencia homosexual. Primeramente, la totalidad de la narración expone una problemática relación entre Delmira y todas las mujeres que la rodean. Esto no es obligatoriamente señal de ninguna orientación sexual en particular; pero sí sugiere un trauma que ha privado a la protagonista de sentirse parte de una comunidad acogedora de su individualidad. Esa sensación de no pertenecer puede entenderse tanto como causa o como efecto de su inconformidad con el papel tradicional que desempeñan las mujeres dentro de un esquema social patriarcal. La Delmira adulta confiesa su inherente dualidad en su aun activa jornada formativa: “Encontré a mi padre y lo perdí. Inspirada por Lope ${ }^{64}$ fingí ser diversas, creí ser una y otra persona, mostré con decisión, predilecciones que fui cambiando, opté por gestos y gustos de los que después deserté. Me enamoré una y otra vez... Me vestí de hombre por amor a una mujer” (254). Se trata de una revelación

\footnotetext{
${ }^{64}$ En el teatro español del Siglo de Oro el motivo de la mujer vestida de hombre es muy común, incluyendo algunas obras de Lope de Vega. Comúnmente el disfraz varonil era utilizado por el personaje femenino con la intención de descubrir los engaños de un amante y no se le asocia con tendencias homosexuales. En algunas obras, como explica Luis M. González, existen mujeres que "se comportan como hombre por deseo propio... y que se caracterizan por tener muchas de las características propias del hombre" (61). Éstas últimas tampoco se vinculan necesariamente a la orientación lesbiana, más bien, se utilizaban para exaltar cualidades supuestamente masculinas como la valentía y la inteligencia que no podían atribuirse sin más a las mujeres.
} 
ambigua y, hay que reconocer, debatible. No obstante podemos explorar otros indicios al respecto que sugieren la presencia de una heroína homosexual en este Bildungsroman. El rechazo cruel que padece la niña en una casa llena de mujeres no tiene razón aparente. Sabemos que tanto la madre como la abuela la privan de todo signo afectivo. Yolanda Melgar Pernías propone que "la razón de la hostilidad que recibe la protagonista por parte de la abuela reside en su desviación de las normas apropiadas de comportamiento femenino, seguidas, como es de esperar, por las demás chicas de Agustini, lo que la convierte en un caso perdido” (206). La nana Dulce la "mandaba salir” de la cocina cada vez que entraba a la cocina "aunque la estufa estuviera muy del otro lado de la enorme cocina”, lo cual sugiere que todas las figuras de autoridad femenina en la casa han acordado no perder tiempo en instruir a la niña en asuntos domésticos, como si careciera de toda habilidad o inclinación "natural” por el trabajo de la casa. Y en efecto, Delmira siente repulsión por las labores domésticas femeninas -“Me da asco pensar que voy a tomar clases de cocina, de bordado, de tejido” (151). La respuesta a la sinrazón de la marginación que tiene que soportar en la casa puede hallarse en la “desilusión” que sienten las mujeres tradicionalistas con las que convive, ante la personalidad híbrida y poco femenina de Delmira.

Entre las habilidades de supuesta índole masculina que desempeña Delmira destacan su preferencia por las matemáticas y la literatura. Asegura que hace "más rápidas las cuentas que las hermanitas”, de quienes se burla porque no saben explicar la materia. Tan fáciles le resultan los estudios de las matemáticas que se pone a leer sus libros preferidos “mientras la hermanita explica mal cómo se hacen las cuentas” (151). Además de sus habilidades aritméticas, Delmira es una lectora voraz. Para su fortuna, en 
la casa queda la biblioteca del tío Gustavo, la cual es un verdadero refugio intelectual. Según le explica al profesor de secundaria, con apenas doce años ha devorado textos clásicos de la literatura occidental como El tesoro de la juventud, Las aventuras de Guillermo Tell, Los tres mosqueteros, Los miserables. Entre sus favoritos admite que se encuentran Doctor Jekyll y Robin Hood (151-52). Ambos textos, a primera vista dispares, revelan las impresiones formativas que han moldeado la personalidad de Delmira. Por una parte El extraño caso del doctor Jekyll y el señor Hyde expone la inextricable duplicidad de la naturaleza humana, así como la coexistencia de las fuerzas del bien y el mal. Por otra parte, Robin Hood es un paria del folclor inglés que desafía las reglas del orden establecido y toma la justicia en sus propias manos en pos del beneficio de los más vulnerables. Sus lecturas muestran una especie de sendero de formación intelectual. Ella es, al mismo tiempo, un individuo híbrido, filosóficamente hablando, y una activista social, a tal punto de arriesgar su propia vida en defensa de sus convicciones de justicia.

En base a la acumulación de conocimiento y sus profesados gustos por las matemáticas y la literatura, resulta un tanto sorprendente que Delmira lo que realmente desea estudiar es arqueología (152). Curiosamente, la arqueología es la ciencia que extrae conocimiento en base al estudio de los restos. Del mismo modo que un arqueólogo reconfigura el pasado material de una cultura, Delmira ahora intenta reconstituir su pasado, a partir de los restos que perduran en la memoria. Como quien organiza las piezas de un rompecabezas y ambiciona constituir con ellas una historia coherente, el arqueólogo recopila el material que consigue, lo cual le permite conjeturar y, en gran medida llenar los huecos del pasado en base a los artefactos, con frecuencia incompletos y fragmentados, recuperados del sitio excavado. Delmira, a través del artificio de la 
ficción literaria, escribe empleando el material al cual puede acceder, rellenando también los vacíos del pasado, rescatando y construyendo un pasado que, sin el trabajo de la arqueología de la memoria, pasaría al olvido.

Michel Foucault explica en La arqueología del saber que la historia como campo del saber ha ido transformándose y transformando así su labor narrativa. Se ha alejado de las construcciones totales, acercándose al estudio particularizado y problematizado. Asegura que "la historia, en su forma tradicional, se dedicaba a memorizar los monumentos del pasado, a transformarlos en documentos... [mientras que] en nuestros días, la historia es lo que transforma los documentos en monumentos” (10-11). Es decir, la práctica de la historia más reciente según el teórico ya no solamente se encarga de interpretar y validar el documento sino que ahora:

lo organiza, lo recorta, lo distribuye, lo ordena, lo reparte en niveles, establece series, distingue lo que es pertinente de lo que no es, fija elementos, define unidades, describe relaciones. El documento no es, pues, ya para la historia esa materia inerte a través de la cual trata ésta de reconstruir lo que los hombres han hecho o dicho, lo que ha pasado y de lo cual solo resta el surco: trata de definir en el propio tejido documental unidades, conjuntos, series, relaciones. Hay que separar la historia de la imagen en la que durante mucho tiempo se complació y por medio de la cual encontraba su justificación antropológica: la de una memoria milenaria y colectiva que se ayudaba con documentos materiales para recobrar la lozanía de sus recuerdos (10) 
Dicha tendencia produce discursos históricos fragmentados, discontinuos y paradójicos puesto que desarticula y deslegitima el proyecto de una historia global, total, general. Delmira, similarmente, intenta reconstituir un pasado formativo, construyendo “monumentos” y estableciendo "relaciones" de los restos del pasado que puede y desea recordar.

El vínculo entre la narración de tipo histórica y la ficción literaria ha sido explorado a fondo por Hayden White. En referencia a la tarea de crear una Historia y, en específico a la ficción de la representación de hechos verídicos o "la literatura de los hechos ${ }^{65}$ ”, el crítico arguye que los historiadores “are concerned with events which can be assigned to specific time-space locations, events which are (or were) in principle observable or perceivable, whereas imaginative writers - poets, novelists, playwrights are concerned with both these kinds of events and imagined, hypothetical, or invented ones.” (121). Según la labor de rememoración autobiográfica de Delmira, si puede llamársele así, se evidencia un paralelo filosófico entre la postura de White y la propuesta de Boullosa en este texto. Aunque convencionalmente se ven como disciplinas distintas, White y Boullosa coinciden en que tanto el historiador como el escritor de ficción trabajan con una materia prima similar. Ambos tienen que lidiar, según dicta su oficio, con vacíos temporales, la selección del material de importancia, así como el otorgar protagonismos a unos y restárselo a otros.

Como se mencionó anteriormente, el empleo de Delmira en el exilio consiste en trabajar con un material tanto histórico como literario -los textos de Lope de Vega

${ }^{65}$ Mi traducción 
inspiran su labor creadora y rememoración que, inevitablemente, se hacen parte de su conciencia y cosmovisión. Boullosa, similarmente, desempeña un trabajo históricoliterario en el cual se combinan el dato histórico y la imaginación literaria. Los agradecimientos de Boullosa al concluir la ficción narrativa, parcialmente revelan su “contacto” y modo de comunicación con sus antepasados -“A mi abuela, por supuesto, que me cuida todavía, y con más atención, desde aquel otro lado”. Como vimos en el capítulo dedicado al estudio de Antes, Boullosa cifra en el epígrafe la motivación poética que descubrimos del relato. Allí escogió el poema de Darío. En Treinta años, no tenemos epígrafe, pero no faltan vínculos de inspiración poética. La autora, como lo expresaba Francisco de Quevedo siglos antes, entabla una conversación con sus “difuntos”, que forzosamente la lleva, como a Delmira, a la rememoración, la recreación del pasado y la veneración de la sabiduría ancestral de sus antepasados. En uno de sus sonetos morales, "Desde la Torre”, Quevedo habla del goce de la lectura, de las calladas melodías que produce el acto solitario de la lectura, y la posibilidad de dialogar, a la distancia, con maestros literarios. El poema también presenta grandes temas barrocos - el vivir desengañado, la inevitabilidad de la muerte, el sueño de la vida, la preocupación con la duplicidad y la idea de la máscara, y la vigencia de los muertos que nos forman:

Retirado en la paz de estos desiertos, con pocos, pero doctos libros juntos, vivo en conversación con los difuntos y escucho con mis ojos a los muertos.

Si no siempre entendidos, siempre abiertos, o enmiendan, o fecundan mis asuntos; y en músicos callados contrapuntos al sueño de la vida hablan despiertos.

Las grandes almas que la muerte ausenta, 
de injurias de los años, vengadora, libra, joh, gran don Iosef!, docta la emprenta.

En fuga irrevocable huye la hora; pero aquélla el mejor cálculo cuenta que en la lección y estudios nos mejora (330-31)

La estética barroca que propone Quevedo en el soneto se manifiesta en la narrativa de Boullosa. Los misterios de la vida y la imaginación, así como el carácter efímero de la vida, el gusto por la soledad y lo contradictorio son parte también de la poética boullosiana en Treinta años. Y, sobre todo, hay un paralelo en la intimidad y el diálogo que ambos autores dicen tener con los que han muerto, pero que aún permanecen, inmortalizados por sus obras.

Regresar al pueblo ficcional, al lugar que visita la memoria, no es posible. Los cambios provocados por los proyectos de la modernidad han destruido el espacio mítico de formación de Delmira. Las noticias sobre la destrucción del Agustini de la infancia le llegan al exilio por medio de las cartas de la abuela. Ésta ya no cuenta cuentos, ha pasado de la transmisión oral del mito al registro escrito de actualidades y noticias. Debido al descubrimiento de petróleo en la región y la "explotación de los bosques tropicales”, nada queda de la "maravilla” que era Agustini. (250). Como acertadamente indica Anna Reid, los únicos árboles que sobreviven la destrucción de la selva son los que crecen "sumergidos", como "una memoria del pasado, media escondida, pero imborrable" (175). En el proceso de escribir para acceder a un pasado idealizado, se posibilita la “conversación” que Delmira ansía tener con sus propios antepasados. Así se justifican la ausencia y la pertenencia a una cultura que ha dejado atrás, a la cual accede con la rememoración y la escritura. 
A diferencia del Bildungsroman tradicional, esta novela de formación boullosiana no evade la representación de traumas infantiles y adolescentes irresueltos. No corta con los "fantasmas" del pasado sino que indaga sus consecuencias e implicaciones en el desarrollo individual de la protagonista. Es un Bildungsroman que no insiste en la idea de perfectibilidad individual ni en el propósito del género en su versión masculina, europea, de llegar a un punto sosegado y coherente de consenso entre el individuo y su entorno social. El proceso de formación aquí parte del recuerdo y de la reinterpretación de un pasado personal, con lo que se legitima el espacio narrativo de la memoria como catalizador del proceso de formación mismo. 


\section{CONCLUSIONES}

El Bildungsroman en su modelo clásico, europeo, masculino, se desarrolla como producto de la modernidad. En él se cifran los valores, ideales y proyectos de la sociedad moderna desde finales del siglo XVIII y durante todo el siglo XIX. Se trata, pues, de un género que se origina en gran medida para dar voz y legitimar los valores ilustrados de progreso, perfectibilidad humana e integración social. Las novelas representativas del género en su variante más convencional coinciden en el afán esencialista de desarrollo humano y madurez moral e intelectual ${ }^{66}$. Con el héroe de la novela de formación se pone de manifiesto la propuesta pedagógica del género, el cual procura modelar el proceso formativo de un individuo representativo de su sociedad a medida que éste intenta dar solución a las tensiones entre sus inquietudes individuales y las expectativas de su entorno social.

Como se ha postulado en este trabajo, tanto Ángeles Mastretta como Carmen Boullosa retoman el modelo del Bildungsroman tradicional, adaptándolo a una nueva época, localidad y marco teórico. Sus novelas representativas del género estudiadas aquí encarnan la estética y propuestas ideológicas de la posmodernidad. Ambas narradoras reconceptualizan y redefinen el proceso de formación femenino al tiempo que desarticulan el concepto de madurez individual como un proceso íntegro, coherente y progresivo. En Arráncame la vida, Antes, Mal de amores y Treinta años las escritoras mexicanas ponen de manifiesto la crisis de legitimación de los relatos magisteriales sobre

\footnotetext{
${ }^{66}$ Se percibe dicha uniformidad esencialista tanto en los modelos masculinos como en los femeninos del género en Europa, independientemente de si se logra alcanzar la ansiada madurez o si queda frustrada tal expectativa social.
} 
los que teoriza Lyotard. Sus textos ratifican el desgaste de la idea hegemónica del sujeto integrado y, por ende, cuestionan la supuesta supremacía de todo discurso monológico anclado en verdades monolíticas.

Tres preguntas fundamentales han guiado el enfoque de esta investigación desde sus inicios. En primer lugar quería indagar cómo las novelas de formación de Mastretta y Boullosa pueden entenderse como textos que cuestionan los relatos magisteriales de progreso, educación y madurez que impulsaron el modelo decimonónico del género en la modernidad. Ligada a esta primera pregunta, me propuse averiguar hasta qué punto los textos escogidos representan narrativamente un proceso formativo femenino que desarticula los discursos utópicos de la modernidad que sustentaban la novela de formación tradicional. Finalmente, pretendía entender cómo la adaptación del género clásico provee un modelo idóneo para la construcción de un Bildungsroman femenino posmoderno en México durante las dos últimas décadas del siglo XX, modelo que en última instancia confluye en la crítica de un espacio nacional y cultural distópico y aberrante, donde el género en su variante tradicional ya no tiene cabida.

En Arráncame la vida se subvierte el principal objetivo del género en su forma tradicional -el de presentar un recorrido formativo que culmina una vez que el protagonista alcanza cierto grado de madurez y logra integrarse en la sociedad. Catalina se presenta como un sujeto ingenuo y desinhibido que, debido a su limitada escolaridad, subvierte paródicamente el trayecto formativo o el "despertar" que se da en la variante clásica de la novela. Asimismo, dicha ingenuidad le permite romper con los patrones primordiales y casi sagrados que rigen el desenvolvimiento femenino en la sociedad patriarcal. La expectativa de fidelidad conyugal queda desarticulada y se suplanta por la 
habilidad extraordinaria que exhibe la protagonista de ubicarse en los espacios límite de lo ambiguo e incierto. Igualmente, el papel de madre, sin remordimientos ni reservas morales o religiosas, lo asume como un fastidio biológico, rechazando así el desempeño cumbre de la mujer en la sociedad patriarcal en la cual se desenvuelve. El proceso formativo de Catalina, por tanto, se articula sobre las bases de la negación del recorrido típico del protagonista del Bildungsroman clásico. No se alcanza aquí el estado de madurez e integridad moral que ansiaba la novela de formación tradicional. Mastretta propone, más bien, una apertura y revaloración de los parámetros de las novelas del siglo XIX, puesto que estos ya no son válidos en la narrativa mexicana de formación femenina en la posmodernidad.

Con Antes, Carmen Boullosa postula la irrepresentabilidad del proceso formativo, descartando de plano y negándose radicalmente a ajustar, como sí lo hace Mastretta, el patrón decimonónico del género. La escritora rehúsa legarle a su protagonista innombrada la promesa engañosa, moderna, de un proceso formativo progresivo, poniendo en tela de juicio tanto los presupuestos formales como los ideológicos de la novela de formación. Las carencias afectivas en combinación con la intromisión de los elementos fantásticos característicos de la novela construyen una experiencia infantil que imposibilita el paso a la adolescencia. Con la muerte de la protagonista, una vez que ésta experimenta su primera menstruación, se revela la crítica boullosiana al negligente entorno doméstico en el que se margina la individualidad de la niña y se le condena a la orfandad psíquica y, por consiguiente, al desenlace fatal. El terror de ésta, pues, es representativo del pánico a la exclusión y a la deshumanización que pueden avalarse 
dentro de los postulados de progreso u otros discursos hegemónicos diseminados en la modernidad.

En Mal de amores, Mastretta se centra en la representación del proceso formativo de Emilia, quien subvierte el modelo del género desde otros puntos de enfoque a los que se habían expuesto en Arráncame la vida. Con Emilia se enfatiza, paródicamente, la crianza de la protagonista en un idílico entorno doméstico, en el que se guía y cultiva el desenvolvimiento de la joven tanto en el terreno sentimental como en el social y profesional. Los personajes masculinos de Mal de amores, casi sin excepción, tienen roles de apoyo a la individualidad de Emilia y su afán de superación en el campo de la medicina, de manera que el deseo de escapar del hogar materno que se da en el Bildungsroman tradicional no tiene cabida en esta adaptación de Mastretta. Emilia, protegida como está por el sólido entorno familiar, se dedica a desarticular a nivel personal, los presupuestos de monogamia femenina, y a nivel social, la barrera profesional de la mujer en la profesión médica en el México de la Revolución. El siguiente Bildunsgroman de Boullosa estudiado en este trabajo, Treinta años, reinventa el modelo clásico del género, optando por un recorrido formativo que se construye a partir de la invención y la rememoración de la infancia. La nostalgia por el lugar, vivido e imaginado, provocada por la distancia del exilio, la hacen reconstruir una edad dorada. No se presentan la edad de la infancia y la adolescencia como caminos idealizados hacia la madurez adulta. Por el contrario, para Delmira la única época que merece el doloroso esfuerzo del recuerdo es el tiempo mítico de la infancia en el pueblo ficticio de Agustini, a pesar de los traumas que dicha época evoca. La labor de recuperación y reconstrucción de la memoria que desempeña Delmira alude a la 
naturaleza fragmentada de la memoria, hecho que, a su vez, sugiere el fraccionamiento del individuo en su contexto posmoderno.

Finalmente, el proceso de revisión del modelo clásico del Bildungsroman que asumen Mastretta y Boullosa demuestra la versatilidad narrativa del género. Sus respectivas muestras del modelo novelístico apuntan a la vigencia y adaptabilidad de la novela de formación en espacios culturales fundamentalmente distintos al que impulsara el auge de la novela de formación en Europa. La estética posmoderna que permea las novelas estudiadas les permite a las narradoras mexicanas esbozar argumentos en base a la actualidad pragmática y filosófica del México contemporáneo. Ambas escritoras, a su manera, se enfocan en la problemática de la formación femenina para cuestionar la legitimidad de una serie de discursos opresivos y excluyentes que influyen determinantemente en los espacios accesibles a la mujer en la sociedad. Como se ha visto, a través de la desarticulación ya sea del ideal de fidelidad conyugal o del instinto maternal, así como de los efectos de la marginación infantil o la competencia femenina en asuntos de orden público, como lo son el desempeño político o el científico, Mastretta y Boullosa problematizan el proceso formativo femenino. Sus textos, en suma, visibilizan un recorrido formativo abierto, no esencialista ni hegemónico, que en última instancia puede suscitar la apertura crítica e ideológica de los lectores. 


\section{BIBLIOGRAFÍA}

Abel, Elizabeth. Introducción. The Voyage In: Fictions of Female Development. Ed. Elizabeth Abel, Marianne Hirsch, and Elizabeth Langland. Hanover: University Press of New England, 1983. 3-19. Print.

Abraham Hall, Nancy. "Delmira en el exilio: Los treinta años de soledad de Carmen Boullosa.” Wellesley, Recuerdo Ileso. Eds. Elena Gascón Vera and Carlos Ramos. Lleida, Spain: Editorial Milenio, 2002. 179-90. Print.

Anderson, Benedict. Imagined Communities. New York: Verso, 1991. Print.

Anderson, Danny J. "Displacement: Strategies of Transformation in Arráncame la vida, by Angeles Mastretta.” Journal of the Midwest Modern Language Association 21.1 (1988): 15-27. Print.

Apter-Cragnolino, Aída. "Jugando con el melodrama: género literario y mirada femenina en Arráncame la vida de Ángeles Mastretta.” Confluencia: Revista Hispánica de Cultura y Literatura 11.1 (1995): 126-33. Print.

Avedaño, Nadia Dolores. "The Contemporary Feminist Bildungsroman in Ángeles Mastretta, Isabel Allende and, Lucha Corpi.” Diss. U of Arizona, 2003. Print.

Bailey, Kay E. "El uso de silencios en Arráncame la vida por Ángeles Mastretta.” Confluencia: Revista Hispánica de Cultura y Literatura 7.1 (1991): 135-42. Print.

Bakhtin, Mikhail "The Bildungsroman and its Significance in the History of Realism.” Trans. Vern W. McGee Speech Genres and Other Late Essays. Ed. Caryl Emerson and Michael Holquist. Austin: University of Texas Press, 1986. 10-59. Print.

Barrera, Trinidad. “Tácticas, estrategias y utopías de Ángeles Mastretta” Ínsula: Revista de letras y ciencias humanas 618-619 (1998): 33-35. Print.

Bauman, Zygmunt. "Postmodernity or Living with Ambivalence.” A Postmodern Reader. Ed. Joseph Natoli and Linda Hutcheon. Albany: State University of New York, 1993. 9-24. Print.

---. Vidas desperdiciadas: La modernidad y sus parias. Barcelona: Paidós, 2013. Print.

Beauvoir, Simone de. The Second Sex. New York: Alfred A. Knopf, 2010. Print.

Beer, Gabriella de. “Interview with Ángeles Mastretta” Review: Latin American Literature and Arts 48 (1994): 14-17. Print. 
Beville, Maria. Gothic-postmodernism: Voicing the Terrors of Postmodernity. Amsterdam: Rodopi, 2009. Print.

Bojalil Daou, Andreé. "Estar loca en la Puebla del siglo XIX: El hospital de San Roque” Diss. Universidad de las Américas Puebla, 2009. Web. 16 Jan. 2014.

Boullosa, Carmen. Antes. D.F.: Punto de lectura, 2001. Print.

---. Treinta años. D.F.: Alfaguara, 1999. Print.

Buckley, Jerome Hamilton. Season of Youth: The Bildungsroman from Dickens to Golding. Cambridge: Harvard UP, 1974. Print.

Bury, John B. The Idea of Progress. New York: Cosimo, 2008. Print.

Camayd-Freixas, Erik. Realismo mágico y primitivismo: Relecturas de Carpentier, Asturias, Rulfo y García Márquez. Lanham: University Press of America, 1998. Print.

Chodorow, Nancy. The Reproduction of Mothering: Psychoanalysis and the Sociology of Gender. Berkeley: University of California Press, 1978. Print.

Clark D’ Lugo, Carol. “Before They Disappear: Reassessing Cultural (De)Formation in Mexico”. Acercamientos a Carmen Boullosa. Ed. Barbara Dröscher and Carlos Rincón. Berlín: Tranvía Sur, 1999. 68-74. Print.

Corbatta, Jorgelina. Feminismo y escritura femenina en Latinoamérica. Buenos Aires: Corregidor, 2002. Print.

Coria-Sánchez, Carlos Mateo. "Contextualización del feminismo en México en la narrativa de Ángeles Mastretta." Diss. U of Georgia, 1999. Print.

Cortázar, Julio. “Algunos aspectos del cuento” Cuadernos Hispanoamericanos 25 (1971): 403-06. Print.

Doub, Yolanda A. Journeys of Formation: The Spanish American Bildungsroman. New York: Peter Lang Publishing, 2010. Print.

Dröscher, Barbara. “La muerte de las madres”. Acercamientos a Carmen Boullosa. Ed. Barbara Dröscher and Carlos Rincón. Berlín: Tranvía Sur, 1999. 59-67. Print.

Ebert, Teresa L. “The 'Difference' of Postmodern Feminism” College English 53.8 (1991): 886-904. Print. 
Edwards, Alice. “Coming of Age in Latin America: Women's Writing and the Bildungsroman.” Diss. U of Pittsburg, 1998. Print.

Finnegan, Naula, and Jane E. Lavery. Introduction. The 'Boom Femenino' in Mexico. Ed. Finnegan and Lavery. Newcastle: Cambridge Scholars Publishing, 2010. Print.

Foucault, Michel. La arqueología del saber. México, D.F.: Siglo XXI Editores, 1997. Print.

Franco, Jean. “Apuntes sobre la crítica feminista y la literatura hispanoamericana” Hispamerica 15.45 (1986): 31-43. Print.

---. Plotting Women: Gender and Representation in Mexico. New York: Columbia University Press, 1989. Print.

Fuentes, Marcelo E. “El cantante, el gobernador, su mujer y su amante” Taller de Letras 35 (2004): 45-58. Print.

Gallardo, Julianna Laufenberg. "Partículas revoltosas: La infancia en la literatura fantástica mexicana del siglo XX.” Diss. U of Virginia, 2010. Print.

García Canclini, Néstor. Culturas híbridas: estrategias para entrar y salir de la modernidad. D.F.: Grijalbo, 1990. Print.

García, Kay S. Broken Bars: New Perspectives from Mexican Women Writers. Albuquerque: University of New Mexico Press, 1994. Print.

Gold, Janet N. “Arráncame la vida: Textual Complicity and the Boundaries of Rebellion” Chasqui: Revista de literatura latinoamericana 17 (1988): 35-40.

González, Luis M. “La mujer en el teatro del Siglo de Oro español” Teatro: Revista de estudios teatrales 6-7 (1995): 41-70. Print.

Habra, Hedy. “Transferencia de la imagen paterna en Arráncame la vida: del juego infantil al juego erótico y agónico” La Mujer En La Literatura Del Mundo Hispánico. Ed. Juana Arancibia. Westminster, CA: Instituto Literario y Cultural Hispánico, 2005. 139-59. Print.

Hernández Enríquez, Virginia. "Educación femenina y transgresión en Mal de amores.” Las miradas de la crítica: Los discursos de la cultura hoy. Eds. Rosaura Hernández Monroy, Manuel F. Medina, and Javier Durán. Azcapotzalco, México: Universidad Autónoma Metropolitana, 2001. 275-89. Print.

Hirsch, Marianne. "The Novel of Formation as Genre: Between Great Expectations and Lost Illusions.” Genre 12 (1979): 293-311. Print. 
---. The Mother/Daughter Plot: Narrative, Psychoanalysis, Feminism. Bloomington: Indiana University Press. 1989. Print.

Hostos, Eugenio María de. Ensayos. Barcelona: Linkgua ediciones, 2007. eBook Collection (EBSCOhost). Web. 3 Feb. 2016.

Hutcheon, Linda. The Politics of Postmodernism. London: Routledge. 2002. Print.

---. A Poetics of Postmodernism: History, Theory, Fiction. Cambridge: Routledge. 1988. Print.

Jameson, Fredric. "Postmodernism and Consumer Society." The Critical Tradition: Classic Texts and Contemporary Trends. Ed. David H. Richter. Boston: Bedford/St. Martin’s, 2007. 1956-66. Print.

Jaramillo-Tallabs, Sandra Elizabeth. "Historias de vida. La mujer en la medicina” Medicina Universitaria 12.46: 2010: 70-78. Print.

Jones, Hazel. Jane Austen and Marriage. London: Continuum. 2009. Print.

Juan-Navarro, Santiago. Postmodernismo y metaficción historiográfica: Una perspectiva interamericana. Valencia: Universitat de València. 2002. Print.

Kleinbord Labovitz, Esther. The Myth of the Heroine: The Female Bildungsroman in the Twentieth Century. New York: Peter Lang, 1986. Print.

Kontje, Todd. Private Lives in the Public Sphere: The German Bildungsroman as Metafiction. University Park: Pennsylvania State University Press, 1992. Print.

Kristeva, Julia. The Powers of Horror: An Essay on Abjection. New York: Columbia University Press, 1982. Print.

Kushigian, Julia A. Reconstructing Childhood: Strategies of Reading for Culture and Gender in the Spanish American Bildungsroman. London: Associated University Presses. 2003. Print.

Lagos, Maria Ines. En tono mayor: Relatos de formación de protagonista femenina en Hispanoamérica. Santiago de Chile: Cuarto Propio. 1996. Print.

Lavery, Jane Elizabeth. Ángeles Mastretta: Textual Multiplicity. Suffolk: Tamesis, 2005. Print.

Lutes Leasa Y. Allende, Buitrago, Luiselli: Aproximaciones teóricas al concepto del

"Bildungsroman" femenino. New York: Peter Lang, 2000. Print. 
Lemaître León, Monique J. “La historia oficial frente al discurso de la 'Ficción’ femenina en Arráncame la vida de Ángeles Mastretta.” Texto Crítico 2.3 (1996): 99-114. Print.

Llarena, Alicia. "Voces femeninas en la novela mexicana actual: la infancia como estrategia en Carmen Boullosa y Bárbara Jacobs.” Congreso de la Asociación Española de Estudios Hispanoamericanos, January, 1994. Lleida: España, 1996. 363-78. Print.

Lukács, Georg. The Theory of the Novel. Cambridge: The M.I.T. Press, 1971. Print.

Lyotard, Jean-François. La condición posmoderna: Informe sobre el saber. Madrid: Cátedra, 1987. Print.

---. “Defining the Postmodern” The Critical Tradition: Classic Texts and Contemporary Trends. Ed. David H. Richter. Boston: Bedford/St Martin’s, 2007. 1933-35. Print.

Macías, Anna. Against all Odds: The Feminist Movement in Mexico to 1940. Westport: Greenwood Press, 1982. Print.

Malloy, Carolyn. "La escritura de Ángeles Mastretta: Memorias a la deriva.” La Otredad: Los discursos de la cultura hoy, 1995. Ed. Silvia Elguea Véjar. Mexico City, Mexico: Universidad Autónoma Metropolitana-A, 1997. 27-34. Print.

Maloof, Judy. "Mal De Amores: Un Bildungsroman Femenino.” Revista de literatura mexicana contemporánea 5.11 (1999): 36-43. Print.

Malpas, Simon. Jean-François Lyotard. London: Routledge, 2003. Print.

Martínez Alfaro, María Jesús. "Intertextuality: Origins and Development of the Concept.” Atlantis 18. 1-2 (1996): 268-85. Print.

Mastretta, Ángeles. Arráncame la vida. Barcelona: Seix Barral, 2006. Print.

---. Mal de amores. Buenos Aires: Booket, 2009. Print.

---. El mundo iluminado. México, D.F.: Cal y arena, 1998. Print.

McHale, Brian. Postmodernist Fiction. New York: Routledge, 1987. Print.

Melgar Pernías, Yolanda. Los Bidungsromane femeninos de Carmen Boullosa y Sandra Cisneros: Mexicanidades, Fronteras, Puentes. Woodbridge: Tamesis, 2012. Print.

---. "Madres e hijas en los Bildungsromane femeninos de Carmen Boullosa: Mejor desaparece, Antes y Treinta años.” Iberoamericana 10.40 (2010): 27-45. Print. 
Molina Sevilla de Morlelock, Ela. Relecturas y narraciones femeninas de la Revolución Mexicana: Campobello, Garro, Esquivel y Mastretta. Rochester: Tamesis, 2013. Print.

Moretti, Franco. The Way of the World: the Bildungsroman in European Culture. London: Verso, 1987. Print.

Mujica, Bárbara. “Ángeles Mastretta: women of will in love and in war” Américas 49 (1997): 36-43. Print.

Nicol, Brian. Introduction. Postmodernism and the Contemporary Novel: A Reader. Ed. Brian Nicol. Edinburgh: Edinburgh University Press, 2002. 1-10. Print.

Oviedo, José Miguel. Historia de la literatura hispanoamericana: Volumen 4: De Borges al presente. Madrid: Alianza, 2005. Print.

Paz, Octavio. El laberinto de la soledad y otras obras. New York: Penguin Books, 1997. Print.

Pearson, Carol Elizabeth. "Gender, Genre and Resistance in the Works of Lucha Corpi, Angeles Mastretta, and Claribel Alegría.” Diss. U of New Mexico, 1998. Print.

Pfeiffer, Erna. Entrevistas: diez escritoras mexicanas desde bastidores. Frankfurt: Vervuert, 1992. Print.

Quevedo, Francisco de. “Desde La Torre” Poesía Lírica Del Siglo De Oro. Ed. Elías L. Rivers. Madrid: Cátedra, 2009. 330-31. Print.

Reid, Anna. “Treinta años”. La Palabra y el Hombre: Revista de la Universidad Veracruzana 112 (1999): 173-77. Web. 11 Nov. 2015.

---. "Haunting inheritances: persecution and the uncanny in Carmen Boullosa's novel Antes [Before]” Journal of Romance Studies 12.1 (2012): 39-55. Print.

---. "Transformado la infancia: elementos góticos en la narrative de Carmen Boullosa” Revista de Literatura Mexicana Contemporánea 9.20 (2003): 96-104. Print.

Rivera Villegas, Carmen M. "Las mujeres y la Revolución Mexicana en Mal de amores de Ángeles Mastretta” Letras femeninas 24 (1998): 37-48. Print.

Rodríguez-Pimentel, Leticia, and Silva-Romo, Rodolfo. “Aportaciones de la mujer a la medicina” Gaceta Médica de México 139.6 (2003): 635-38. Print.

Rosowski, Susan J. “The Novel of Awakening” Genre 12 (1979): 313-32. Print. 
Rousseau, Jean Jacques. Emilio o La educación. Middletown: CreateSpace Independent Publishing Platform, 2015. Print.

Saussure, Ferdinand de. "Nature of the Linguistic Sign”.The Critical Tradition: Classic Texts and Contemporary Trends. Ed. David H. Richter. Boston: Bedford/St Martin's, 2007. 842-51. Print.

Selden, Raman, Widdowson, Peter, and Brooker, Peter. A Reader's Guide to Contemporary Literary Theory. Harlow: Pearson, 2005. Print.

Sklodowska, Elzbieta. La parodia en la nueva novela hispanoamericana (1960-1985). Amsterdam/Philadelphia: John Benjamins Publishing Company, 1991. Print.

Spielmann, Ellen. “Entrevista con Carmen Boullosa.” Acercamientos a Carmen Boullosa. Ed. Barbara Dröscher and Carlos Rincón. Berlin: Tranvía Sur, 1999. 261-65. Print.

Vague, Stephanie Leigh. "A Life of One's Own: Mexican Fictions of Female Development.” Diss. U of Iowa, 2004. Print.

Walczak, Grazyna. "La selva como espacio de abusos múltiples. Una lectura Ecocrítica de dos novelas mexicanas” Encuentros 11.1 (2013): 149-59. Print.

Waugh, Patricia. Feminine Fictions: Revising the Postmodern. London: Routledge, 1989. Print.

White, Hayden. Tropics of Discourse: Essays in Cultural Criticism. Baltimore: The Johns Hopkins University Press, 1978. Print.

Woolf, Virginia. Una habitación propia. Barcelona: Seix Barral, 2008. Print.

Yúdice, George. “¿Puede hablarse de Posmodernidad en América Latina?” Revista de crítica literaria latinoamericana 15.29 (1989): 105-28. Print. 
VITA

\section{REBECA CUNILL}

Born, Havana, Cuba

\section{EDUCATION}

2006

B.A., Spanish

B.A., Psychology

Certificate, Women Studies

Florida International University, Miami, FL

2008

M.A., Spanish

Florida International University, Miami, FL

2011

Ph.D. Candidate in Spanish

Florida International University, Miami, FL

2013

TESOL/FLE Professional Graduate Certificate

Florida International University, Miami, FL

\section{CONFERECNE PRESENTATIONS AND PUBLICATIONS}

“Legitimación imperial a partir de la subalternización del sujeto primitivo en Naufragios y Cabeza de Vaca.” $3^{\text {rd }}$ International Conference on Caribbean Studies. Marquette University, April 11 ${ }^{\text {th }}, 2013$

"Infantilización y paternalismo: representación de la mujer en Electra de Benito Pérez Galdós.” $37^{\text {th }}$ International Symposium of Hispanic Literature. California State University, March 9 ${ }^{\text {th }}, 2012$.

"Representación de espacios públicos y privados en Arráncame la vida de Ángeles Mastretta.” $19^{\text {th }}$ Colloquium on Hispanic and Luzo-Brazilian Literatures and Linguistics. University of Texas at Austin, February 25 ${ }^{\text {th }}, 2011$.

“Ambigüedad en la figura del antihéroe en Flores de papel de Egon Wolff.” Society for the Interdisciplinary Study of Social Imagery Twentieth Annual Conference. Colorado State University, June 2010. 
"Paralelos entre Contrapunteo cubano del tabaco y el azúcar de Fernando Ortiz y Los pasos perdidos de Alejo Carpentier." 5th Interdisciplinary Colloquium on Spanish and Latin American Literatures, Linguistics and Cultures. University of Florida, February $25^{\text {th }}, 2010$. 